\title{
Flora da Bahia: Melastomataceae - Tibouchina s.l.
}

\section{Juliana Gomes Freitas ${ }^{*}$, Andrea Karla Almeida dos Santos ${ }^{2, a}$, Paulo José Fernandes Guimarães ${ }^{3, b}$ \& Reyjane Patricia Oliveira ${ }^{1, c}$}

${ }^{1}$ Programa de Pós-Graduação em Botânica, Departamento de Ciências Biológicas, Universidade Estadual de Feira de Santana, Feira de Santana, Bahia, Brasil.

${ }^{2}$ Instituto Multidisciplinar em Saúde, Universidade Federal da Bahia, Vitória da Conquista, Bahia, Brasil.

${ }^{3}$ Instituto de Pesquisas Jardim Botânico do Rio de Janeiro, Rio de Janeiro, Brasil.

\begin{abstract}
Resumo - É apresentado o tratamento taxonômico de Tibouchina s.l. no estado da Bahia, Brasil. São reconhecidas 37 espécies, uma delas como Pleroma (P. michelangelii). Quatro espécies são novos registros para o Nordeste (T. crassiramis, T. elegans, T. granulosa e T. sebastianopolitana), 25 são endêmicas da Bahia e nove restritas à Chapada Diamantina. O tratamento inclui chave de identificação, descrições, ilustrações, comentários e mapas de distribuição das espécies no estado.
\end{abstract}

Palavras-chave adicionais: biodiversidade, Melastomeae, Pleroma, taxonomia

\begin{abstract}
Flora of Bahia: Melastomataceae - Tibouchina s.1.) - A taxonomic treatment of Tibouchina s.l. from Bahia, Brazil, is presented. Thirty-seven species are recognized, one of them in Pleroma ( $P$. michelangelii). Four species are new records for Northeast Brazil ( $T$. crassiramis, T. elegans, T. granulosa and T. sebastianopolitana), 25 are endemic to the state and nine restricted to the Chapada Diamantina.
\end{abstract} The treatment includes an identification key, descriptions, illustrations, comments, and distribution maps of the species in the state.

Additional key words: biodiversity, Melastomeae, Pleroma, taxonomy.

Melastomataceae (Myrtales) compreende cerca de 5.000 espécies (Renner et al. 2016), distribuídas nas regiões tropicais e subtropicais de todo o mundo, com aproximadamente dois terços dessa diversidade restrita à região Neotropical (Goldenberg et al. 2012; Renner et al. 2016). A família apresenta hábito arbóreo, arbustivo, subarbustivo, herbáceo, raramente lianescente ou epifítico, e folhas simples, opostas ou raramente verticiladas, com venação acródroma, em geral com nervura marginal e sem estípulas. As flores são bissexuadas, actinomorfas, diplostêmones, solitárias ou reunidas em inflorescências, com estames de anteras poricidas, ovário súpero, ínfero ou fundido ao hipanto em graus variados, pluriovulado. Os frutos são baciformes ou capsulares (para uma descrição formal da família, veja Fagundes \& Santos 2016). No Brasil, é a quinta maior família de angiospermas, com 69 gêneros e 1.390 espécies, 911 endêmicas (BFG 2015). Ocorre em todos os estados e domínios fitogeográficos, nos mais variados tipos de vegetação (Baumgratz et al. 2015). No estado da Bahia, está representada por 37 gêneros e aproximadamente 299 espécies (BFG 2015).

\section{Tibouchina Aubl.}

Árvore, arbusto ou subarbusto; ramos cilíndricos, subcilíndricos ou quadrangulares, alados, subalados ou

\footnotetext{
*Autora para correspondência: julebiologia@gmail.com;

andreakarlaufba@gmail.com;

bpaulojose.guimaraes@gmail.com; 'rpatricia@uefs.br

Editor responsável: Alessandro Rapini

Submetido: 31 maio 2016; aceito: 18 nov. 2016

Publicacão eletrônica: 15 dez. 2016 ; versão final: 16 dez. 2016
}

não alados, glabros ou revestidos por tricomas; nós circundados por tricomas mais longos formando uma coroa ou com tricomas curtos e iguais aos dos entrenós. Folhas opostas, raro verticiladas, pecioladas ou subsésseis; lâmina oval, lanceolada ou elíptica a cordada, coriácea, cartácea ou membranácea, revestida por tricomas em ambas as faces ou raramente glabra, tricomas eretos ou adpressos, neste caso, completamente livres ou envolvidos parcialmente pela epiderme laminar, 3-9 nervuras. Flores 4- ou 5(6)meras, solitárias ou em tirsos com muitas ou poucas flores; bractéolas em pares ou raramente solitárias, geralmente decíduas, lanceoladas, elípticas ou ovais, retas ou côncavas, involucrais ou não, glabras ou revestidas externamente por tricomas; hipanto campanulado, urceolado ou oblongo, indumento variado, tricomas alternissépalos presentes ou não; sépalas persistentes ou decíduas no fruto, ápice aristado ou não. Estames 8 ou 10(12), dimorfos, isomorfos ou subisomorfos; filetes glabros ou pilosos; conectivos prolongados ou não abaixo das anteras, apêndices ventrais glabros ou com tricomas e/ou glândulas. Ovário com o número de lóculos igual ao de pétalas, livre ou parcialmente adnato ao hipanto, com ápice revestido por tricomas; estilete glabro ou piloso, reto ou curvo; estigma punctiforme ou truncado. Frutos cápsulas formadas pelo hipanto persistente, número de valvas igual ao de pétalas, externamente costado ou não; sementes numerosas, cocleadas, lateralmente achatadas, minutamente tuberculadas.

Tibouchina inclui de 250 a 350 espécies, que ocorrem desde o México e Antilhas até o norte da Argentina e Paraguai (Peralta 2002; Almeda 2009), 
sendo um dos maiores gêneros da tribo Melastomeae (Renner 1993). No Brasil, Tibouchina s.l. compreende 190 espécies (incluindo Pleroma D.Don), 169 endêmicas (BFG 2015). Habitam diversos tipos vegetacionais como restingas, florestas pluviais, matas ciliares, cerrados e campos rupestres (e.g., Guimarães \& Martins 1997; Secco 2006; Meyer 2008; BFG 2015).

Análises filogenéticas (Michelangeli et al. 2013) mostraram que Tibouchina não constitui um grupo monofilético e grande parte de suas espécies será transferida para outros gêneros. Essas mudanças afetarão principalmente as espécies que ocorrem no leste do Brasil, sobretudo na Bahia, que serão transferidas para os gêneros Pleroma e Chaetogastra DC. (Guimarães \& Michelangeli, in prep.). Dessa forma, o presente trabalho considera Tibouchina num sentido amplo, incluindo uma espécie recém-publicada já em Pleroma ( $P$. michelangelii).

Muitas espécies de Tibouchina são conhecidas popularmente e cultivadas como ornamentais. Dentre os nomes populares mais comuns, estão quaresmeira, flor-de-quaresma, manacá, manacá-da-serra, erva-denanã e orelha-de-onça, não havendo especificidades desses nomes para táxons em especial. Contudo, as espécies arbustivas são conhecidas por erva-degarimpeiro na Chapada Diamantina.

\section{Chave para as espécies}

1. Arvoreta 2-4 $\mathrm{m}$ alt. ou árvore 5-20 $\mathrm{m}$ alt.

2. Ramos distais e/ou proximais alados.

3. Face adaxial da lâmina foliar com tricomas adpressos, com base espessada em forma de Y; estilete sem glândulas

16. $T$. granulosa

3'. Face adaxial da lâmina foliar com tricomas não adpressos, simples, sem base espessada; estilete com glândulas estipitadas no terço basal

14. T. fissinervia

2'. Ramos distais e/ou proximais não alados.

4. Bractéolas ovais, côncavas, em forma de caliptra

2. T. arborea

4'. Bractéolas elípticas, elíptico-lanceoladas ou lanceoladas, planas ou côncavas, nunca em forma de caliptra.

5. Folhas com 5 ou 7 nervuras conspícuas na face adaxial.

6. Apêndices estaminais glabros.

7. Ramos distais subcilíndricos, tricomas simples, não adpressos, densos; filetes com tricomas glandulares (glândulas estipitadas)

26. $T$. rigidula

7'. Ramos distais quadrangulares, tricomas dendríticos, parcialmente adpressos, esparsos; filetes com tricomas simples

30. T. stenocarpa

6'. Apêndices estaminais com glândulas estipitadas.

8. Face adaxial da lâmina foliar com tricomas simples, adpressos, circundados por glândulas pediceladas; estilete glabro

15. T. francavillana

8'. Face adaxial da lâmina foliar com tricomas dendríticos, não adpressos, não circundados por glândulas; estilete com tricomas glandulares (glândulas estipitadas)

9. T. candolleana

5'. Folhas com 3 nervuras conspícuas na face adaxial.

9. Folhas com ápice mucronulado a obtuso; filetes glabros

9'. Folhas com ápice agudo; filetes com tricomas ou glândulas.

21. T. macrochiton

10. Filetes com tricomas simples; apêndices estaminais com tricomas glandulares (glândulas estipitadas) em ambos os ciclos

13. T. elegans

10'. Filetes com tricomas glandulares (glândulas estipitadas); apêndices estaminais glabros em ambos os ciclos

4. T. barnebyana

1'. Subarbusto 0,5-1 $\mathrm{m}$ alt. ou arbusto 1-2 $\mathrm{m}$ alt.

11. Folhas com 3 nervuras conspícuas na face adaxial.

12. Inflorescências reduzidas a uma única flor

12'. Inflorescências multifloras, nunca unifloras.

13. Hipanto urceolado; sépalas persistentes no fruto

1. Pleroma michelangelii

13'. Hipanto campanulado; sépalas caducas no fruto

28. T. salviifolia

4. T. barnebyana

11'. Folha com 5-9 nervuras conspícuas na face adaxial.

14. Flores 4-meras.

15. Folhas com lâmina arredondada a cordada, cartácea; anteras lilás ou rosa ..... 5. T. blanchetiana

15'. Folhas com lâmina oval, oboval ou oblonga, membranácea; anteras amarelas.

16. Folhas com tricomas dendríticos (projeções laterais curtas) em ambas as faces da lâmina; hipanto oblongo; filetes com tricomas simples

7. $T$. bradeana

16'. Folhas com tricomas simples em ambas as faces da lâmina; hipanto urceolado; filetes glabros

29. T. sebastianopolitana

14'. Flores 5-meras.

17. Folhas 3-verticiladas

5. T. blanchetiana 
17'. Folhas opostas.

18. Folhas subsésseis (pecíolo menor que $0,3 \mathrm{~cm}$ compr.)

18'. Folhas pecioladas (pecíolo maior que $0,5 \mathrm{~cm}$ compr.).

19. Face abaxial da lâmina foliar com glândulas estipitadas.

20. Ramos com nós circundados por uma coroa de tricomas; lâmina foliar membranácea; filetes glabros

31. T. stipulacea

20'. Ramos com nós não circundados por coroa de tricomas; lâmina foliar coriácea; filetes com glândulas estipitadas 10. T. carvalhoi

19'. Face abaxial da lâmina foliar sem glândulas estipitadas.

21. Sépalas aristadas.

22. Estilete glabro

6. T. bracteolata

22'. Estilete com tricomas glandulares (glândulas estipitadas).

23. Folhas com lâmina 1,5-2,8 cm compr.; hipanto urceolado

23'. Folhas com lâmina 7-12,5 cm compr.; hipanto oblongo

22. T. noblickii

24. T. pauloalvinii

21'. Sépalas não aristadas.

24. Folhas glabras ou somente com glândulas sésseis na face adaxial.

25'. Hipanto oblongo; estilete com tricomas glandulares (glândulas estipitadas) na metade basal

34. T. tomentulosa

25. Hipanto urceolado; estilete glabro.

26. Ramos distais sem glândulas sésseis; bractéolas elípticolanceoladas $0,4-0,6 \times 1-1,5 \mathrm{~cm}$; ovário com tricomas simples no terço apical, densos (sem glândulas estipitadas)

20. T. luetzelburgii

26'. Ramos distais com glândulas sésseis; bractéolas ausentes; ovário com apenas 3-6 glândulas estipitadas no ápice .. 32. T. subglabra

24 '. Folhas com diferentes tipos de indumento na face adaxial.

27. Folhas seríceas ou vilosas, nunca estrigosas ou escabras.

28. Caule levemente alado; face abaxial da lâmina foliar com tricomas dendríticos (com projeções laterais) .... 35. T. urceolaris

28'. Caule não alado; face abaxial da lâmina foliar com tricomas simples (não dendríticos, sem projeções laterais).

29. Ovário totalmente revestido por tricomas ..... 3. T. bahiensis

29'. Ovário com tricomas apenas no ápice.

30. Apêndice do conectivo com glândulas estipitadas nos estames antipétalos

17. T. heteromalla

30'. Apêndice do conectivo glabro em todos os estames.

31. Folhas com lâmina 2,4-4 cm compr.; hipanto urceolado 36. T. velutina

31'. Folhas com lâmina 5-9 cm compr.; hipanto oblongo 18. T. Ihotzkyana

27'. Folhas estrigosas, escabras ou adpresso-escabras, nunca seríceas ou vilosas.

32. Face adaxial da lâmina foliar com tricomas adpressos (típico de Tibouchina sect. barbigerae Naudin), escamados.

37. Tibouchina sp.

32'. Face adaxial da lâmina foliar com tricomas não adpressos e não escamados.

33. Sépalas persistentes no fruto, menores que $0,3 \mathrm{~cm}$ compr. ....

33'. Sépalas caducas, maiores que $0,5 \mathrm{~cm}$ compr.

34. Ramos das inflorescências com tricomas glandulares (glândulas estipitadas; sem tricomas simples ou dendríticos) 25. T. pereirae

34'. Ramos das inflorescências com tricomas simples e/ou dendríticos (sem tricomas glandulares).

35. Apêndices estaminais com glândulas estipitadas em ambos os ciclos

19. T. lithophila 
35'. Apêndices estaminais glabros (sem glândulas estipitadas) em ambos os ciclos.

36. Face adaxial da lâmina foliar com tricomas dendríticos no ápice; hipanto campanulado ... 23. T. oreophila

36'. Face adaxial da lâmina foliar com tricomas simples; hipanto oblongo ou urceolado.

37. Face adaxial da lâmina foliar com tricomas simples, nunca bulados na base 8. T. caatingae

37'. Face adaxial da lâmina foliar com tricomas bulados na base (cônicos).

38. Folhas com lâmina $6-8,5 \times 3-4$ $\mathrm{cm}$; estilete glabro . 11. T. comosa

38'. Folhas com lâmina $1,3-3 \times 0,8-2$ $\mathrm{cm}$; estilete com tricomas simples ..

12. T. crassiramis

1. Pleroma michelangelii P.J.F.Guim. \& J.G.Freitas, Syst. Bot. 40(2): 553. 2015.

Figuras 1S, 2A-D e 3.

Subarbusto ou arbusto $0,4-1,5 \mathrm{~m}$ alt.; ramos distais subcilíndricos, não alados, escabros, tricomas dendríticos, ramos proximais cilíndricos; nós não circundados por coroa de tricomas. Folhas opostas; pecíolo 0,2-0,4 cm compr.; lâmina $1-2 \times 0,4-0,8 \mathrm{~cm}$, oblongo-lanceolada, coriácea, ápice agudo, base obtusa, margem inteira, não ciliada, plana, discolor, face adaxial escabra, tricomas simples, bulados na base, face abaxial estrigosa, tricomas dendríticos e escamas lanceoladas nas nervuras, 3 nervuras basais. Inflorescências reduzidas a uma única flor terminal; bractéolas ca. 1,3 ×0,2 cm, elípticas, não involucrais, tricomas simples. Flores 5-meras; pedicelo 0,1-0,4 cm compr.; hipanto $0,7-0,9 \times 0,4-0,6 \mathrm{~cm}$, oblongo, escabro, tricomas dendríticos; sépalas 0,5-0,9 $\times 0,2$ $0,3 \mathrm{~cm}$, decíduas, ápice agudo, aristado; pétalas 1,5-2,6 $\times \quad 0,8-1,7 \mathrm{~cm}$, obovais, ápice arredondado, lilás. Estames 10, subisomorfos; filetes antissépalos ca. 1,6 $\mathrm{cm}$ compr., antipétalos ca. $1 \mathrm{~cm}$ compr., glabros ou com glândulas estipitadas em ambos os ciclos; conectivos prolongados abaixo das anteras, os antissépalos ca. 0,4 cm compr., os antipétalos ca. 0,2 $\mathrm{cm}$ compr., apêndices glabros em ambos os ciclos; anteras antissépalas ca. $1,4 \mathrm{~cm}$ compr., as antipétalas ca. $1 \mathrm{~cm}$ compr., lilás ou creme. Ovário hirsuto no ápice; estilete reto, glabro; estigma truncado. Cápsulas $0,7-0,9 \times 0,5-0,7 \mathrm{~cm}$, não costadas.

Endêmica da Bahia, na Chapada Diamantina (Guimarães \& Freitas 2015). E6, F6: campos rupestres. Coletada em estágio reprodutivo de maio a outubro.

Material selecionado - Abaíra, $13^{\circ} 15^{\prime} \mathrm{S}, 41^{\circ} 54^{\prime} \mathrm{W}, 21$ maio 1992 (fl.), W. Ganev 320 (HUEFS); Barra da Estiva, 1341'03"S, 41 $17^{\circ} 55^{\prime \prime W}, 10$ out. 2009 (est.), M.L. Guedes et al. 16682 (ALCB); Palmeiras, $12^{\circ} 36^{\prime} 01^{\prime \prime S}, 41^{\circ} 27^{\prime} 17^{\prime \prime} \mathrm{W}, 11$ out. 1987 (fr.), L.P.

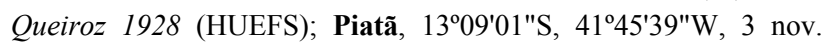
1996 (fl.), H.P. Bautista PCD 4003 (ALCB, HUEFS).

Pleroma michelangelii é reconhecida pelos ramos escabros, com tricomas dendríticos, pequenas folhas
(1-2 cm compr.) oblongo-lanceoladas, com face adaxial escabra e tricomas bulados na base, além das inflorescências reduzidas a uma única flor.

2. Tibouchina arborea (Gardner) Cogn. in Martius \& Eichler, Fl. Bras. 14(3): 299; t. 67. 1885.

Figuras 1A, 2E-I e 3.

Árvore 5-10 m alt.; ramos distais subcilíndricos a quadrangulares, não alados, estrigosos, tricomas dendríticos, ramos proximais cilíndricos; nós não circundados por coroa de tricomas hirsutos. Folhas opostas; pecíolo 1-2 cm compr.; lâmina 5-10 × 2-4 $\mathrm{cm}$, elíptica a oval, coriácea, ápice acuminado, base obtusa, às vezes cuneada, margem inteira a inconspicuamente ondulada, não ciliada, plana, discolor, estrigosa em ambas as faces, tricomas dendríticos, 5 nervuras basais. Inflorescências terminais, raque 7-20 cm compr., tricomas dendríticos; bractéolas ca. 1,5 × $0,9 \mathrm{~cm}$, ovais, côncavas, involucrais (em forma de caliptra), tricomas simples. Flores 5(6)-meras; pedicelo ca. 0,3 cm compr.; hipanto $0,5-0,7 \times 0,5-0,6 \mathrm{~cm}$, campanulado, estrigoso; sépalas $0,8-1 \times$ ca. $0,5 \mathrm{~cm}$, decíduas, ápice apiculado a arredondado, não aristado; pétalas 2,5-3 × 1,5-2 cm, obdeltoides, ápice arredondado, brancas a lilás. Estames 10(12), dimorfos; filetes antissépalos 0,6-0,8 cm compr., os antipétalos ca. 0,6 cm compr., glândulas estipitadas em ambos os ciclos; conectivos prolongados abaixo das anteras, os antissépalos ca. 0,3 cm compr., os antipétalos ca. $0,1 \mathrm{~cm}$ compr., apêndices com glândulas estipitadas em ambos os ciclos; anteras antissépalas $1-1,3 \mathrm{~cm}$ compr., as antipétalas $0,9-1 \mathrm{~cm}$ compr., brancas ou lilás. Ovário hirsuto no terço apical; estilete curvo, tricomas simples na metade basal; estigma punctiforme. Cápsulas $0,8-1 \times$ ca. 0,5 $\mathrm{cm}$, não costadas.

Endêmica do Brasil, ocorre na Bahia, Espírito Santo, Minas Gerais, Rio de Janeiro e São Paulo (BFG 2015). G8, H8: floresta ombrófila, no litoral sul do estado. Coletada com flores em novembro e dezembro. 


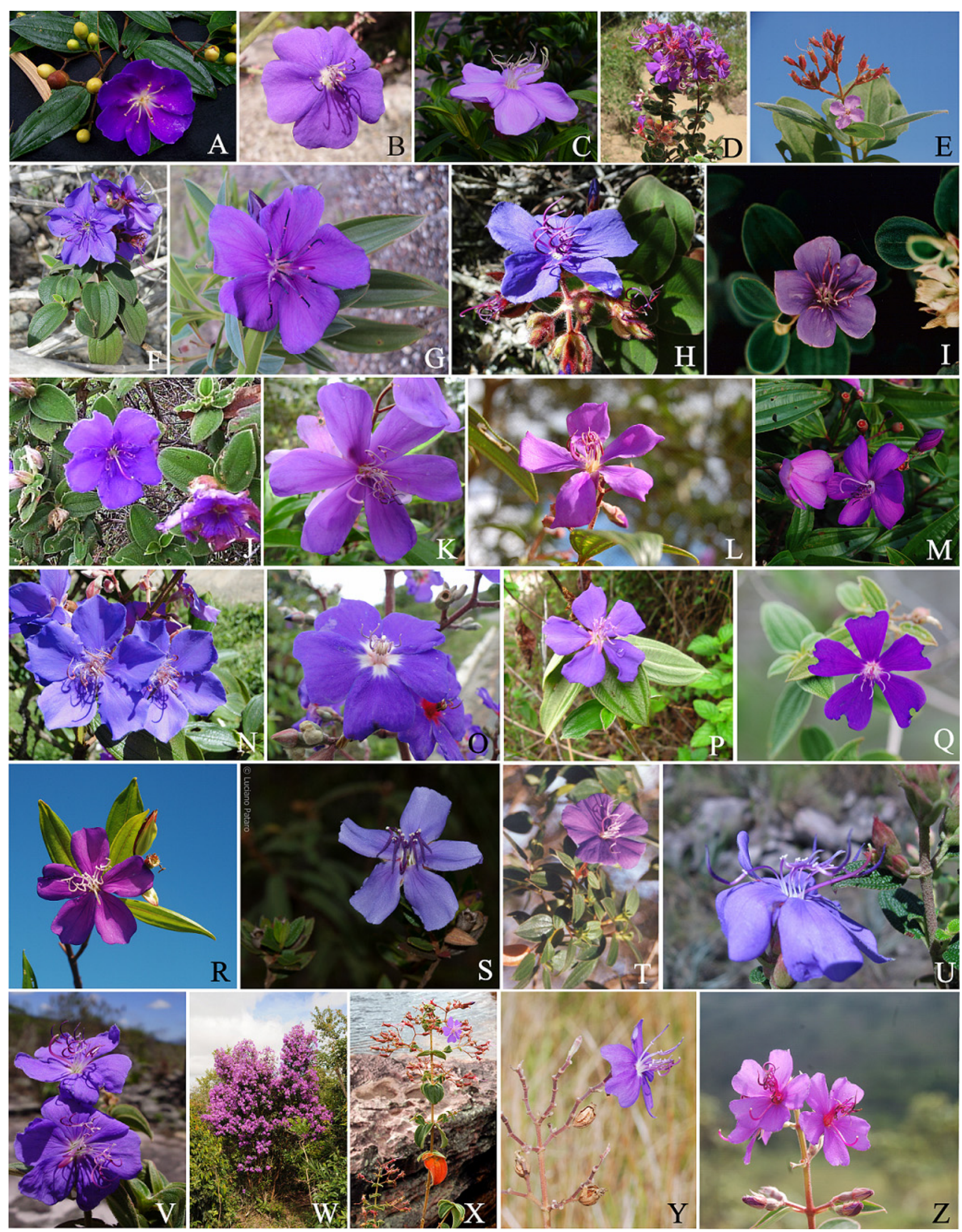

Figura 1. Flores das espécies de Tibouchina s.l. do estado da Bahia: A- T. arborea; B- T. bahiensis; C- T. barnebyana; D- T. blanchetiana; E- T. bradeana; F- T. caatingae; G- T. candolleana; H- T. carvalhoi; I- T. comosa; J- T. crassiramis; K- T. elegans; L- T. fissinervia; M- T. francavillana; N- T. granulosa; O- T. heteromalla; P- T. lhotzkyana; Q- T. lithophila; R- T. macrochiton; S- Pleroma michelangelii; T- T. noblickii; U- T. oreophila; V- T. pereirae; W- T. rigidula; X- T. riparia; Y- T. urceolaris; Z- T. velutina. (Fotos: A- A.J. Jardim; B- A.K. Santos; C, V- A.F.P. Machado; D, H, J, L, N, O, Q, U, X, Z- J.G. Freitas; E, R, W, Y- E. Mattos; F- M.D.R. Teixeira; G- R.P. Oliveira; IA.A.Conceição; K, M- C.S.Silva-Lima; P- J.G.C.Sobrinho; S- L.Pattaro; T- E.Mello). 

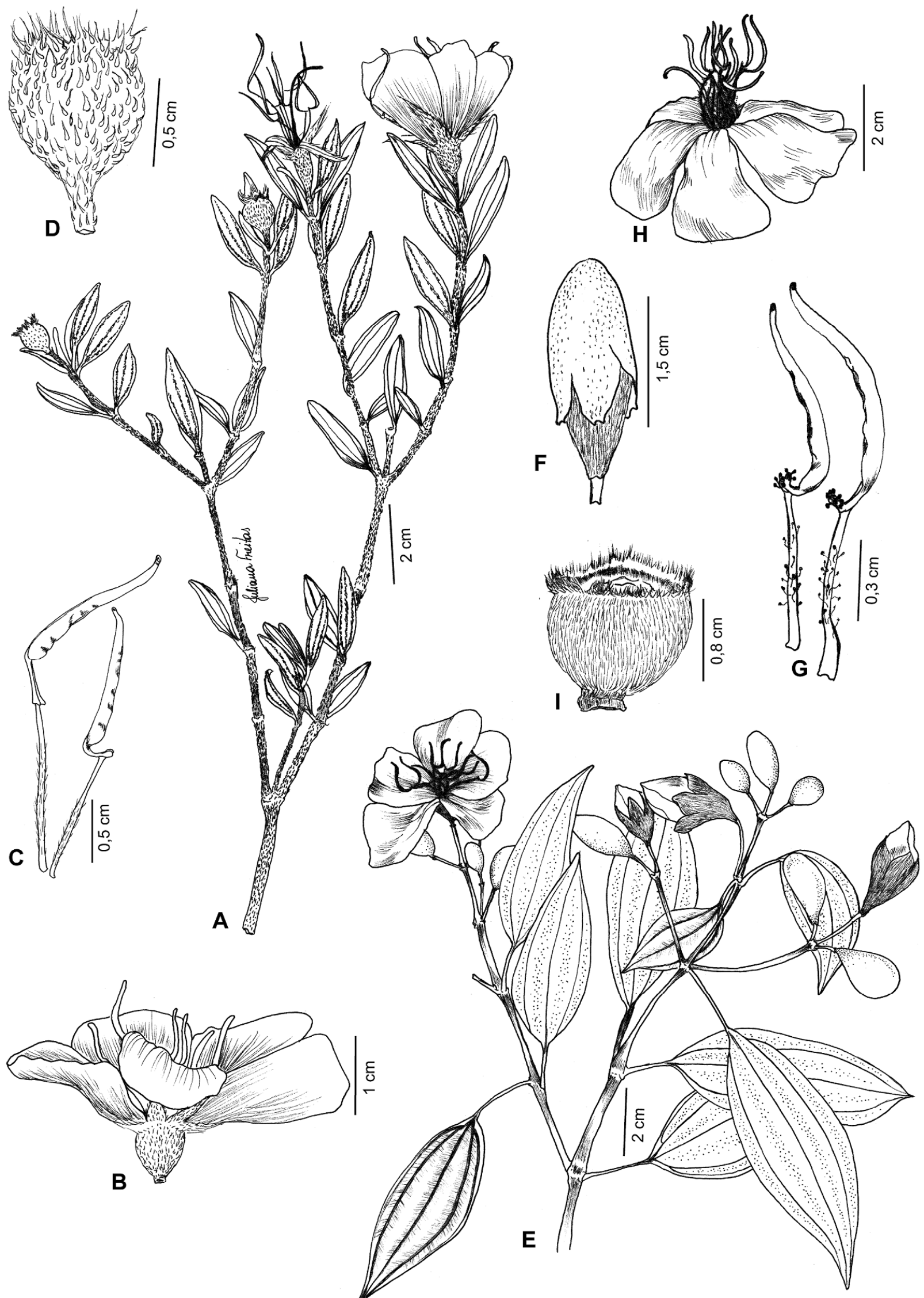

Figura 2. A-D. Pleroma michelangelii: A- ramo com flores e frutos; B- flor; C- estames de ambos os ciclos; D- fruto (Ganev 320 HUEFS). E-I. Tibouchina arborea: E- ramo com botões e flores; F- botão floral evidenciando bractéola em forma de caliptra; G- estames dos dois ciclos; H- flor; I- fruto (Lopes 304 CEPEC). 


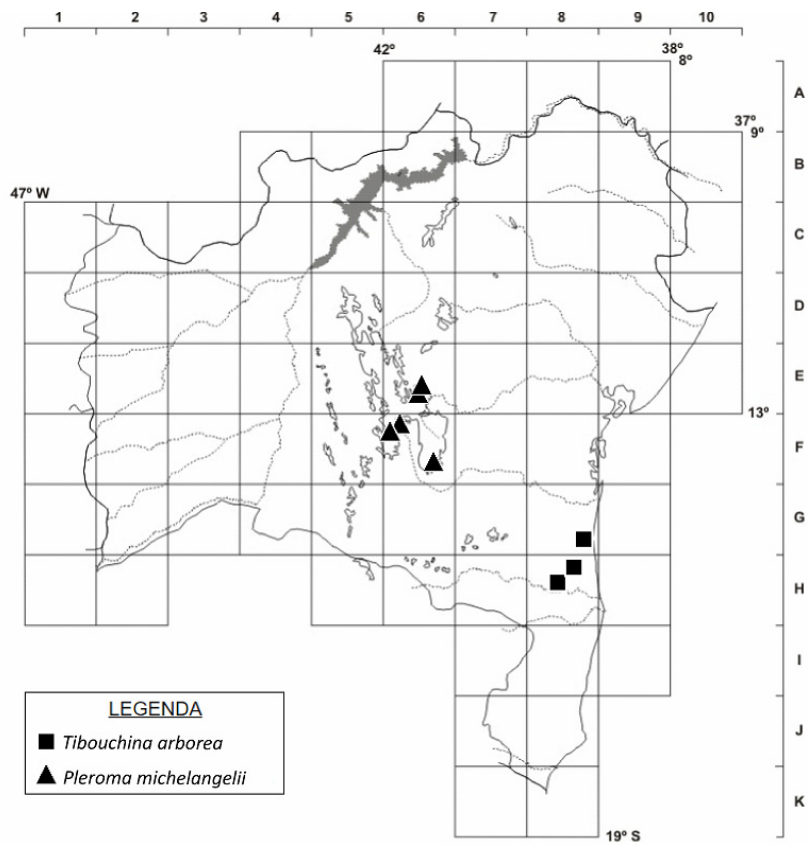

Figura 3. Mapa de distribuição geográfica de Tibouchina arborea e Pleroma michelangelii no estado da Bahia.

Material selecionado - Arataca, $15^{\circ} 10^{\prime} 27^{\prime \prime}$ S, 39 $20^{\prime} 22^{\prime \prime} \mathrm{W}$, s.d. (bot., fl.), J.G. Jardim 4826 (CEPEC); Barro Preto, 1446'13"S, 39¹2'10"W, 21 nov. 2005 (fl.), M.M.M. Lopes et al. 304 (CEPEC); Camacan, 15²3'30"S, 39³3'55"W, 9 dez. 2006 (fl.), R.A.X. Borges et al. 293 (CEPEC).

Tibouchina arborea possui ramos distais não alados, sem a coroa de tricomas circundando os nós, bractéolas involucrais em forma de caliptra, filetes com glândulas estipitadas e estilete com tricomas na metade basal. Assemelha-se a $T$. fissinervia e $T$. francavillana pelo hábito arbóreo e flores lilás, tornando-se brancas com a senescência. Entretanto, nenhuma dessas duas espécies apresenta bractéolas involucrais em forma de caliptra. Além disso, T. fissinervia possui ramos distais subalados, com a coroa de tricomas circundando os nós e bractéolas elíptico-lanceoladas, enquanto $T$. francavillana possui filetes com tricomas filiformes simples, sem glândulas, estilete glabro e bractéolas lanceoladas.

3. Tibouchina bahiensis Wurdack, Phytologia 45(4): 321. 1980.

Figura 1B, 4A-D e 5.

Arbusto 1-2 $\mathrm{m}$ alt.; ramos distais quadrangulares, não alados, escabros, tricomas simples, ramos proximais subcilíndricos; nós não circundados por coroa de tricomas. Folhas opostas; pecíolo $0,5-1 \mathrm{~cm}$ compr.; lâmina 4,5-9,5 × 3,5-6 cm, oval, coriácea, ápice obtuso, base cordada, margem inteira, não ciliada, plana, discolor, estrigosa em ambas as faces, tricomas simples, 7 ou 9 nervuras basais. Inflorescências terminais, raque $25-30 \mathrm{~cm}$ compr., tricomas simples; bractéolas não vistas. Flores 5meras; pedicelo $0,1-0,3 \mathrm{~cm}$ compr.; hipanto ca. $0,5 \times$ $0,3 \mathrm{~cm}$, urceolado, estrigoso, tricomas simples; sépalas $0,2-0,4 \times 0,1-0,3 \mathrm{~cm}$, decíduas, ápice agudo, não aristado; pétalas ca. 1,7 × 1,2 cm, obdeltoides, ápice arredondado, lilás. Estames 10, dimorfos; filetes antissépalos ca. $0,8 \mathrm{~cm}$ compr., os antipétalos ca. 0,5 cm compr., glândulas estipitadas em ambos os ciclos; conectivos prolongados abaixo das anteras, os antissépalos ca. 0,2 cm compr., glândulas estipitadas, os antipétalos ca. $0,15 \mathrm{~cm}$ compr., glabros; anteras antissépalas ca. 0,6 cm compr., as antipétalas ca. 0,4 $\mathrm{cm}$ compr., lilás. Ovário híspido, todo revestido de tricomas simples, mais densamente no ápice; estilete curvo no ápice, tricomas simples na metade basal; estigma punctiforme. Cápsulas ca. 0,6 × 0,4 cm, costadas.

Endêmica da Bahia (BFG 2015), no sul do estado. I8, J8: restingas. Coletada em estágio reprodutivo em setembro, janeiro e maio.

Material selecionado - Itamaraju, Parque Nacional do Monte Pascoal, 7 maio 1976 (bot.), J.L. Hage 152 (CEPEC); Porto Seguro, Parque Nacional do Monte Pascoal, 6 jan. 1973 (bot., fl.), T.S. Santos 2716 (CEPEC).

Tibouchina bahiensis é reconhecida por apresentar ramos distais com folhas esparsamente distribuídas, inflorescências pouco ramificadas, além de estames dimorfos com apêndices glabros em apenas um dos ciclos e ovário todo revestido por tricomas simples. É morfologicamente semelhante a $T$. heteromalla pela forma oval e consistência das folhas e pelos estames dimorfos com conectivos antipétalos encurvados. Contudo, T. heteromalla possui folhas congestas nos ramos distais e glândulas estipitadas nos apêndices de ambos os ciclos de estames, além do ovário com tricomas apenas no ápice.

\section{Tibouchina barnebyana Wurdack, Brittonia 33(3):} 304. 1981.

Figuras $1 \mathrm{C}, 4 \mathrm{E}-\mathrm{H}$ e 5.

Arvoreta ou árvore $2-10 \mathrm{~m}$ alt.; ramos distais quadrangulares, não alados, estrigosos, tricomas simples, ramos proximais cilíndricos; nós não circundados por coroa de tricomas. Folhas opostas; pecíolo $0,5-0,8 \mathrm{~cm}$ compr.; lâmina 2,5-6,7 × 0,9-3,3 $\mathrm{cm}$, oval-lanceolada, cartácea, ápice agudo, base acuminada a obtusa, margem inteira, levemente ciliada, às vezes revoluta, discolor, estrigosa em ambas as faces, tricomas simples, circundados por glândulas sésseis, 3 nervuras basais. Inflorescências axilares e terminais, raque 5-15 cm compr., tricomas simples; bractéolas $0,9-1,7 \times 0,6-1 \quad \mathrm{~cm}$, elípticas, não involucrais, tricomas simples. Flores 5-meras; pedicelo $0,5-0,9 \mathrm{~cm}$ compr.; hipanto $0,3-0,6 \times 0,3-0,5 \mathrm{~cm}$, campanulado, estrigoso, tricomas simples; sépalas ca. $0,3 \times 0,2-0,4 \mathrm{~cm}$, decíduas, ápice agudo, não aristado; pétalas 2,5-3,5 × 1,8-2,5 cm, obovais, ápice obtuso, róseas a púrpura. Estames 10, subisomorfos; filetes antissépalos ca. $2 \mathrm{~cm}$ compr., os antipétalos ca. $1,5 \mathrm{~cm}$ compr., glândulas estipitadas em ambos os ciclos; conectivos prolongados abaixo das anteras, os antissépalos ca. $0,3 \mathrm{~cm}$ compr., os antipétalos até 0,2 cm compr., apêndices glabros em ambos os ciclos; 

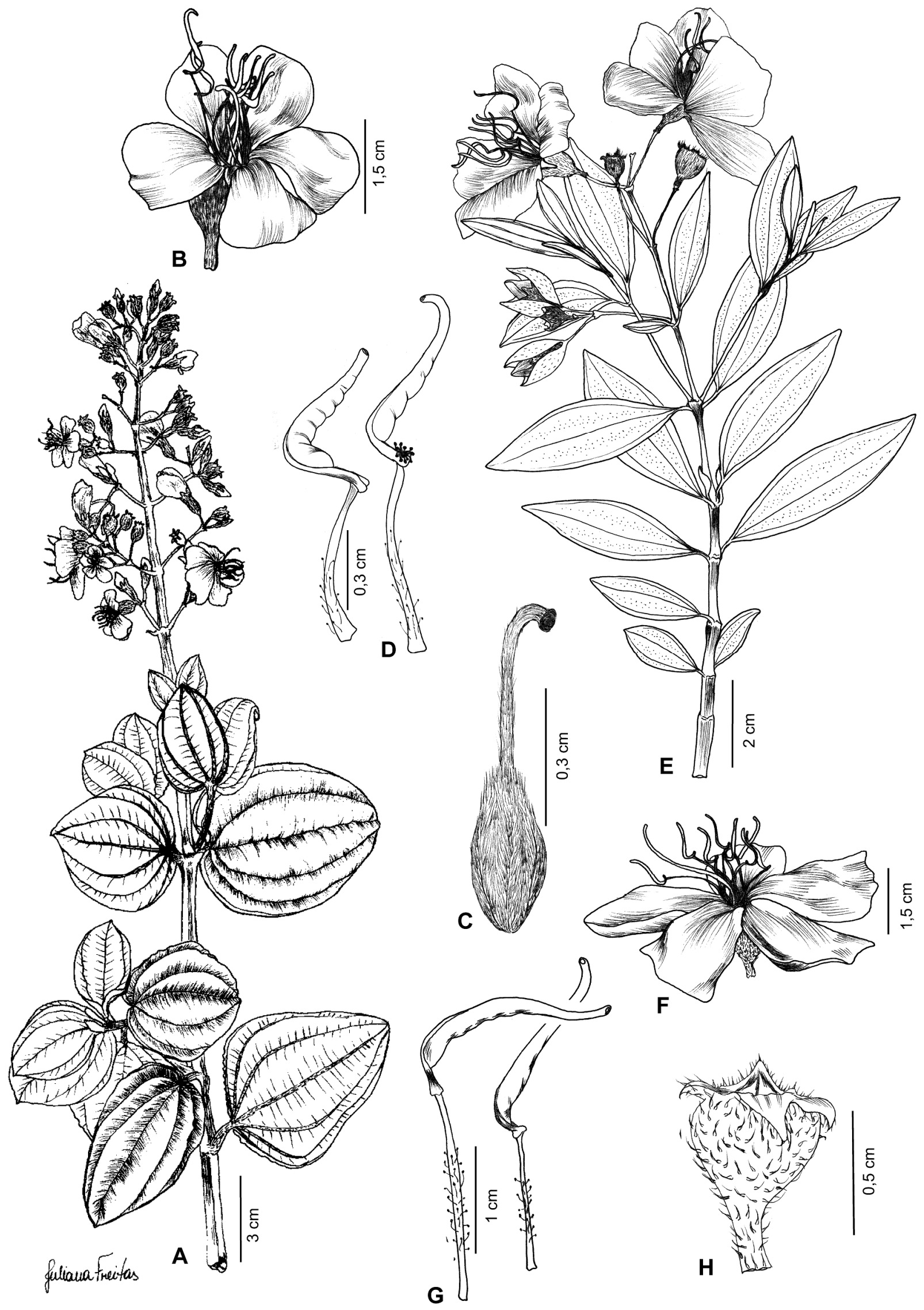

Figura 4. A-D. Tibouchina bahiensis: A- ramo com botões, flores e frutos; B- flor; C- gineceu; D- estames dos dois ciclos (Hage 152 CEPEC). E-H. T. barnebyana: E- ramo com botões, flores e frutos; F- flor; G- estames dos dois ciclos; H- fruto (França 4037 HUEFS). 


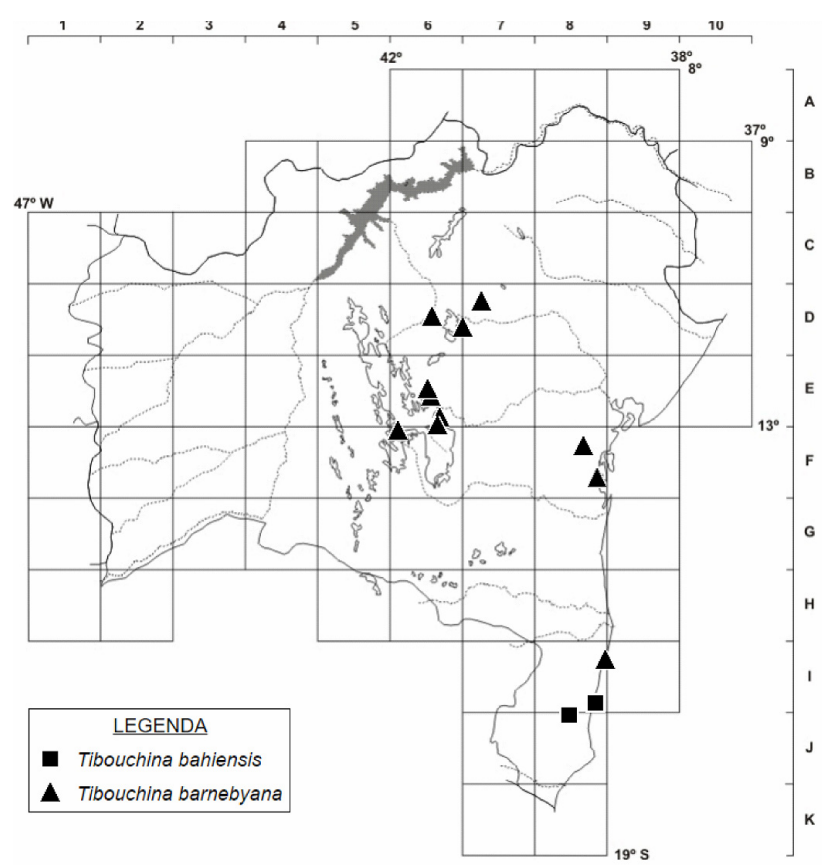

Figura 5. Mapa de distribuição geográfica de Tibouchina bahiensis e T. barnebyana no estado da Bahia.

anteras antissépalas ca. $1 \mathrm{~cm}$ compr., as antipétalas ca. $0,7 \mathrm{~cm}$ compr., róseas. Ovário hirsuto no terço apical; estilete curvo no ápice, tricomas simples na metade basal; estigma punctiforme. Cápsulas $0,5-0,7 \times$ ca. 0,5 $\mathrm{cm}$, não costadas.

Endêmica do Brasil, ocorrendo em Minas Gerais e Bahia (BFG 2015). D6, D7, E6, F6, F8, I8: campos rupestres, margens de rios, cachoeiras e córregos, amplamente distribuída na Chapada Diamantina, piemonte da diamantina e litoral sul do estado. Coletada em estágio reprodutivo em quase todos os meses do ano.

Material selecionado - Andaraí, 12 ${ }^{\circ} 52^{\prime} 15^{\prime \prime} \mathrm{S}, 4^{\circ} 18^{\prime} 25^{\prime \prime} \mathrm{W}, 14$ fev. 1997 (fl., fr.), T.R. Santos PCD 5642 (ALCB, CEPEC, HUEFS); Lençóis $12^{\circ} 33^{\prime} 00^{\prime \prime S}, 4^{\circ} 26^{\prime} 00^{\prime \prime} \mathrm{W}, 10$ ago. 1993 (fl., fr.), L.S. Funch 437 (HUEFS); Morro do Chapéu, 11\%37'02"S, 40 59'28"W, 29 jan. 2003 (fl.), F. França 4037 (HUEFS); Mucugê,

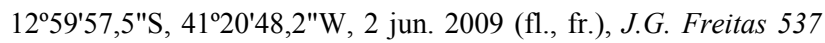

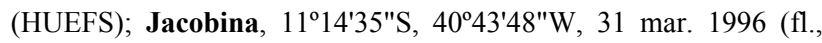
fr.), A.M. Giulietti PCD2679 (ALCB, HUEFS); Palmeiras, $12^{\circ} 25^{\prime} 43^{\prime \prime S}, 4129^{\prime} 30^{\prime \prime W}, 29$ jun. 1995 (fr.), M.L. Guedes et al. PCD 1996 (ALCB); Piatã, 1307'52"S, 4149'57"W, 19 set. 2004 (bot., fl.), M.L. Guedes et al. 11282 (ALCB, CEPEC).

Tibouchina barnebyana é reconhecida por apresentar folhas com três nervuras primárias basais e indumento estrigoso, tricomas simples circundados por glândulas sésseis, estames isomorfos com glândulas estipitadas nos filetes. Os espécimes adultos apresentam porte arbóreo, apesar de alguns indivíduos jovens serem observados em fase reprodutiva, dando a impressão de possuírem hábito arbustivo. É morfologicamente semelhante a $T$. macrochiton, em relação ao hábito arbóreo, inserção das folhas nos ramos e número de nervuras, mas distinguem-se pelos estames isomorfos e filetes glabros em T. macrochiton.
5. Tibouchina blanchetiana Cogn. in Martius \& Eichler, Fl. Bras. 14(3): 351. 1885.

Figuras 1D, 6A-E e 7.

Subarbusto ou arbusto 0,5-1,5 $\mathrm{m}$ alt.; ramos distais subcilíndricos, às vezes quadrangulares, não alados, seríceos, tricomas simples, ramos proximais cilíndricos; nós não circundados por coroa de tricomas. Folhas 3-verticiladas, raro opostas, subsésseis ou pecioladas; pecíolo 0,2-0,5 cm compr.; lâmina 1-3 $\times$ 0,6-2,5 cm, arredondada a cordada, cartácea, ápice obtuso a apiculado, base cordada a obtusa, margem inteira, não ciliada, plana, discolor, serícea em ambas as faces, tricomas simples, 5 nervuras basais. Inflorescências terminais, raque $3-12 \mathrm{~cm}$ compr., tricomas simples; bractéolas não vistas. Flores (4)5meras; pedicelo 0,2-0,4 cm compr.; hipanto $0,5-0,7 \times$ 0,3-0,5 cm, urceolado, seríceo, tricomas simples; sépalas $0,5-0,7 \times$ ca. $0,3 \mathrm{~cm}$, decíduas, ápice cuspidado, não aristado; pétalas 1,3-1,5 × 1-1,4 cm, obdeltoides, ápice truncado, lilás a púrpura. Estames (8)10, subisomorfos; filetes antissépalos $0,8-1 \mathrm{~cm}$ compr., os antipétalos ca. $2,3 \mathrm{~cm}$ compr., glabros ou com tricomas simples em ambos os ciclos; conectivos prolongados abaixo das anteras, os antissépalos ca. 0,2 cm compr., os antipétalos ca. 0,1 cm compr., glabros em ambos os ciclos; anteras antissépalas ca. $1 \mathrm{~cm}$ compr., as antipétalas ca. $0,8 \mathrm{~cm}$ compr., lilás ou róseas. Ovário hirsuto no terço apical; estilete curvo no ápice, seríceo, tricomas simples, às vezes glabro; estigma punctiforme. Cápsulas ca. $0,6-0,8 \times$ ca. 0,6 cm, seríceas, não costadas.

Endêmica da Bahia (BFG 2015), na Chapada Diamantina, piemonte da diamantina e bacia do Paraguaçu. C7, D6, D7, E6, E7: cerrado (campos rupestres). Coletada com flores e frutos em quase todos os meses do ano.

Material selecionado - Itaberaba, $11^{\circ} 19^{\prime} \mathrm{S}, 44^{\circ} 11^{\prime} \mathrm{W}, 13$ nov. 1983 (fr.), H.P. Bautista et al. 1231 (CEPEC, HRB); Jacobina, $11^{\circ} 14^{\prime} \mathrm{S}, 40^{\circ} 28^{\prime} \mathrm{W}, 20$ fev. 1993 (fl.), A.M. Carvalho et al. 4184 (CEPEC); Lençóis, $12^{\circ} 18^{\prime} \mathrm{S}, 41^{\circ} 21^{\prime} \mathrm{W}, 15$ dez. 2005 (fl., fr.), $A . A$.

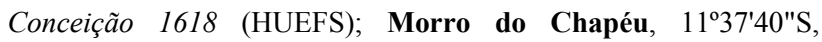
4100'05"W, 28 jun. 1996 (fl., fr.), N. Hind et al. PCD 3168 (HRB); Palmeiras, $12^{\circ} 27^{\prime} 33^{\prime \prime S}, 41^{\circ} 28^{\prime} 39^{\prime \prime} \mathrm{W}, 4$ nov. 2009 (fl., fr.), J.G. Freitas 614 (HUEFS); Ruy Barbosa, 12²18'35"S, 40²9'3"W, 4 set. 2004 (fl., fr.), L.P. Queiroz 9481 (HUEFS); Senhor do Bonfim, $10^{\circ} 31^{\prime} 02^{\prime \prime S}, 40^{\circ} 14^{\prime} 55^{\prime W}, 28$ out. 2005 (fl., fr.), S.F. Conceição 303 (HUEFS); Umburanas, 10²1'49"S, 41 ${ }^{\circ} 11^{\prime} 44^{\prime \prime W}, 28$ jun. 2004 (fl.), M. Machado 237 (HUEFS).

Tibouchina blanchetiana é reconhecida especialmente pelas folhas pequenas $(1-3 \times 0,6-2,5$ $\mathrm{cm})$, cordadas, geralmente verticiladas, com margens avermelhadas, seríceas, e pelas inflorescências congestas (Figura 1D). É morfologicamente semelhante a $T$. velutina, devido ao hábito, consistência das folhas e coloração das flores. Distinguem-se pelas folhas opostas, elípticas ou ovais, com pecíolo longo e ápice apiculado, além das inflorescências com flores mais dispersas, em $T$. velutina. 

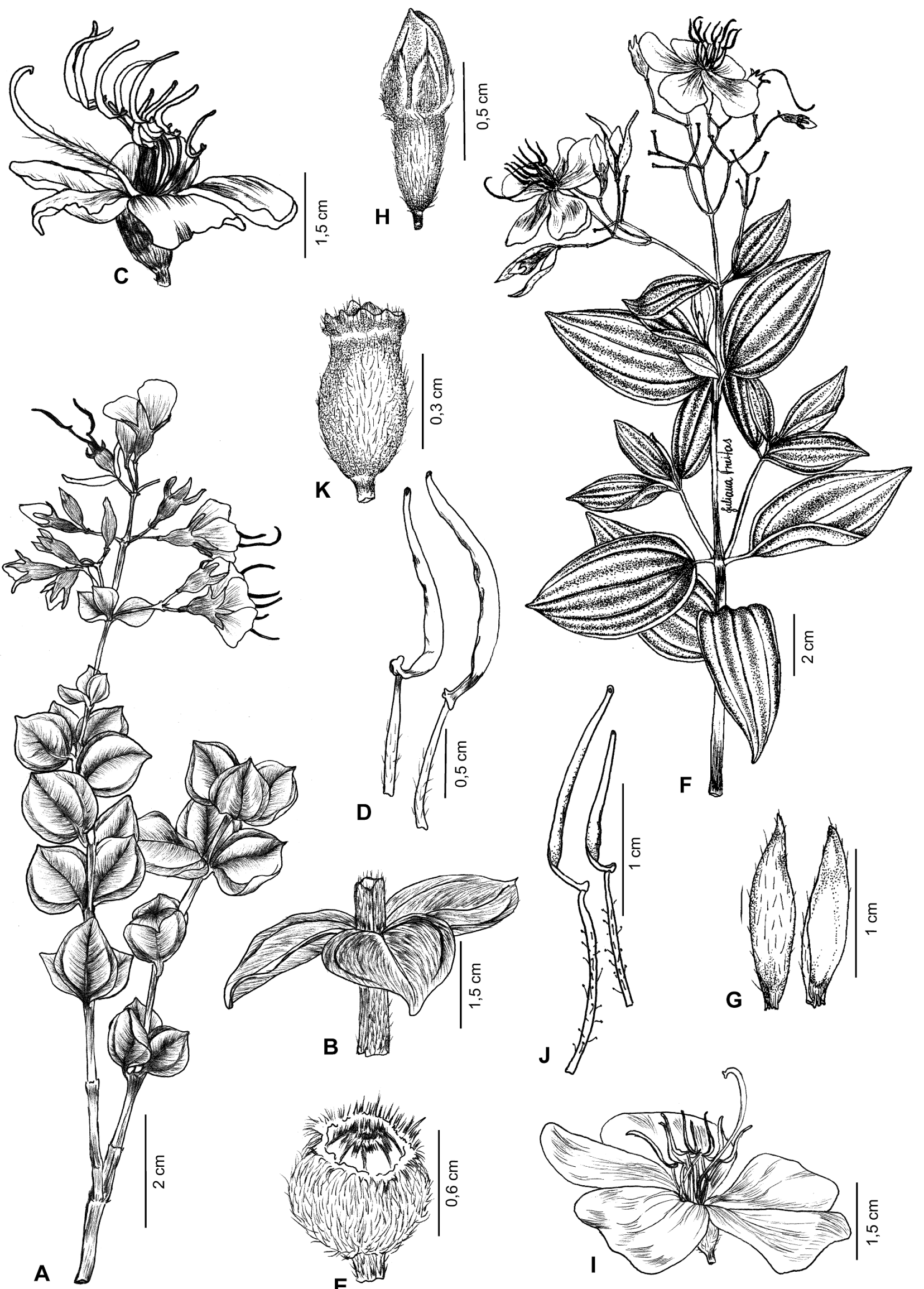

A
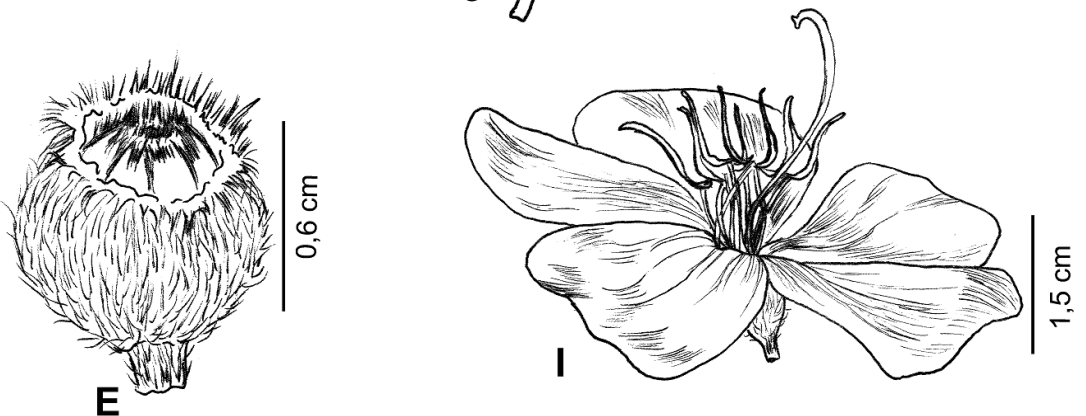

Figura 6. A-E. Tibouchina blanchetiana: A- ramo com botões e flores; B- detalhe do ramo, mostrando folhas verticiladas; C- flor. Destames dos dois ciclos; E- fruto (Freitas 614 HUEFS). F-K. T. bracteolata: F- ramo com botões e flores; G- bractéola, face externa e interna; H- botão floral evidenciando as sépalas com aristas; I- flor; J- estames dos dois ciclos; K- fruto (Silva-Pereira 55 HUEFS). 
6. Tibouchina bracteolata J.G.Freitas, A.K.A.Santos \& R.P.Oliveira, Syst. Bot. 37(1): 190. 2012. Figuras $6 \mathrm{~F}-\mathrm{K}$ e 7.

Arbusto 1-1,5 $\mathrm{m}$ alt.; ramos distais subcilíndricos, não alados, estrigosos, tricomas simples, ramos proximais cilíndricos; nós não circundados por coroa de tricomas. Folhas opostas; pecíolo 1-1,5 cm compr.; lâmina 4,5-6,5 × 2-3,5 cm, oval, coriácea, ápice acuminado, base obtusa, margem inteira, não ciliada, plana, discolor, estrigosa em ambas as faces, tricomas simples, 5 nervuras basais. Inflorescências terminais, raque 10-20 cm compr., tricomas simples; bractéolas $1-1,5 \times 0,3-0,5 \mathrm{~cm}$, elípticas, não involucrais, tricomas simples. Flores 5-meras; pedicelo ca. 0,3 cm compr.; hipanto $0,6-1 \times$ ca. $0,4 \mathrm{~cm}$, oblongo, estrigoso, tricomas simples; sépalas $0,2-0,4 \times$ ca. $0,2 \mathrm{~cm}$, decíduas, ápice agudo, aristado; pétalas 2,5-3 × 1,5-2 cm, obdeltoides, ápice truncado, lilás. Estames 10, dimorfos; filetes antissépalos ca. 1,5 cm compr., os antipétalos ca. $1 \mathrm{~cm}$ compr., glândulas estipitadas em ambos os ciclos; conectivos prolongados abaixo das anteras, os antissépalos ca. 0,4 cm compr., os antipétalos ca. $0,1 \mathrm{~cm}$ compr., apêndices glabros em ambos os ciclos; anteras antissépalas ca. 1,3 cm compr., as antipétalas ca. $1 \mathrm{~cm}$ compr., lilás. Ovário hirsuto no terço apical; estilete reto, glabro; estigma punctiforme. Cápsulas $0,7-1,2 \times$ $0,3-0,5 \mathrm{~cm}$, não costadas.

Endêmica da Bahia, conhecida apenas da Chapada Diamantina (Freitas et al. 2012). E6: mata ciliar. Coletada com flores em dezembro, março e abril.

Material selecionado - Lençóis, $12^{\circ} 34^{\prime} \mathrm{S}, 41^{\circ} 23^{\prime} \mathrm{W}, 30$ abr. 2003 (bot., fl.), V. Silva-Pereira 55 (HUEFS).

Tibouchina bracteolata é reconhecida pelas inflorescências laxas e delicadas, botões florais protegidos por duas longas bractéolas membranáceas e sépalas com ápice aristado. Essas características a

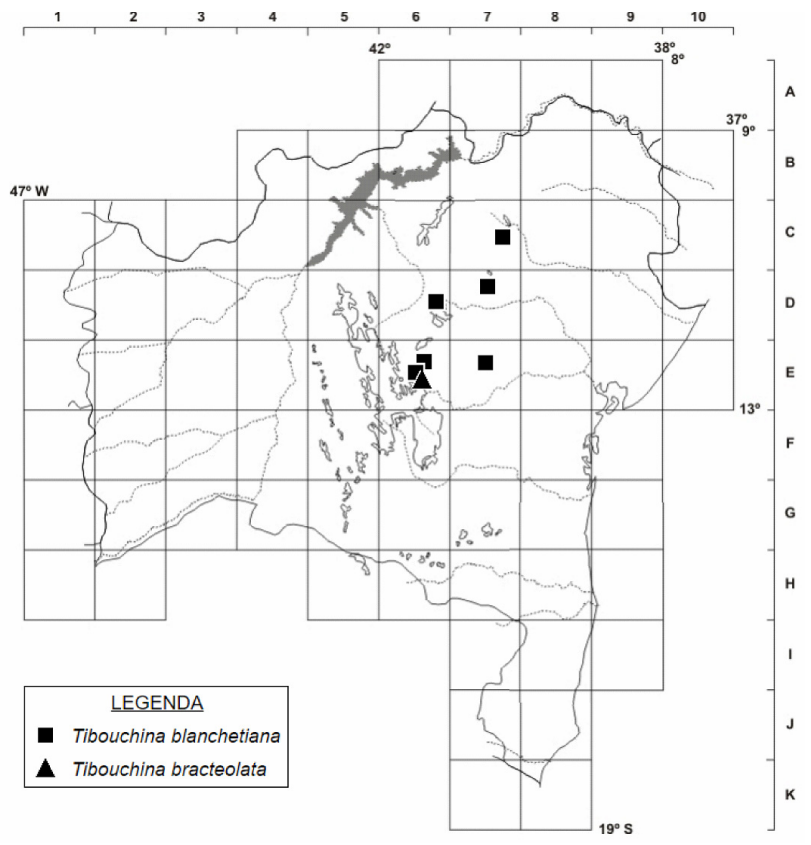

Figura 7. Mapa de distribuição geográfica de Tibouchina blanchetiana e T. bracteolata no estado da Bahia. tornam diferente morfologicamente das demais espécies de Tibouchina encontradas na Bahia.

7. Tibouchina bradeana S.S.Renner, Nord. J. Bot. 14(1): 101. 1994.

Figuras 1E, 8A-D e 9.

Subarbusto ou arbusto $0,8-1,5 \mathrm{~m}$ alt.; ramos distais quadrangulares, não alados, seríceos, glândulas estipitadas, ramos proximais cilíndricos; nós não circundados por coroa de tricomas. Folhas opostas; pecíolo 0,3-2 cm compr.; lâmina 2-6 × 1-4,6 cm, oboval, membranácea, ápice arredondado a mucronulado, base truncada a obtusa, margem denticulada, não ciliada, plana, levemente discolor, estrigosa em ambas as faces, tricomas dendríticos (projeções laterais curtas), 5 nervuras basais. Inflorescências terminais, raque $3-10 \mathrm{~cm}$ compr., tricomas simples e glândulas estipitadas; bractéolas ca. $0,3 \times 0,1 \mathrm{~cm}$, elípticas, não involucrais, tricomas simples. Flores 4-meras; pedicelo 0,1-0,4 cm compr.; hipanto $0,5-0,7 \times 0,3-0,5 \mathrm{~cm}$, oblongo, estrigoso, tricomas simples; sépalas ca. 0,3 $\times 0,2 \mathrm{~cm}$, persistentes, ápice agudo, aristado; pétalas 0,7-1 × 0,6-0,9 cm, obovais ápice obtuso, róseas a púrpura. Estames 10, dimorfos; filetes antissépalos ca. 0,8 cm compr., os antipétalos ca. 0,5 cm compr., tricomas simples em ambos os ciclos; conectivos prolongados abaixo das anteras, os antissépalos ca. 0,5 cm compr., os antissépalos ca. 0,3 cm compr., apêndices glabros em ambos os ciclos; anteras antissépalas ca. $0,8 \mathrm{~cm}$ compr., as antipétalas ca. 0,6 cm compr., amarelas. Ovário hirsutos no terço apical; estilete reto, glabro; estigma punctiforme. Cápsulas $0,8-1 \times 0,5-0,7 \mathrm{~cm}$, costadas.

Endêmica da Bahia, na região metropolitana de Salvador e litoral sul do estado (Renner 1994; BFG 2015). F8, F9: restinga. Coletada em estágio reprodutivo de junho a outubro.

Material selecionado - Ituberá, $13^{\circ} 42^{\prime} 27^{\prime \prime} \mathrm{S}, 39^{\circ} 00^{\prime} 53^{\prime \prime} \mathrm{W}, 21$ jun. 2005 (bot., fl.), J.G. Jardim et al. 4649 (CEPEC); Salvador, $12^{\circ} 56^{\prime} 00^{\prime \prime} \mathrm{S}, 38^{\circ} 21^{\prime} 00^{\prime \prime} \mathrm{W} 20$ set. 2002 (fl.), J.R. Santos-Silva 3 (HUEFS).

Tibouchina bradeana apresenta folhas membranáceas, obovais, com margem denticulada, estrigosa, com tricomas dendríticos (projeções laterais curtas), hipanto oblongo e flores 4-meras. Possui alguma semelhança morfológica com $T$. pauloalvinii, pelo hábito, as folhas membranáceas e o hipanto oblongo. Contudo, T. pauloalvinii se distingue pelas folhas oval-elípticas, seríceas, com tricomas simples, margem inteira e flores 5-meras.

8. Tibouchina caatingae J.G.Freitas, Syst. Bot. 38(2): 418. 2013.

Figuras 1F, 8E-I e 9.

Arbusto 0,8-1,5 $\mathrm{m}$ alt.; ramos distais quadrangulares, não alados, esparso-estrigosos, às vezes glabros, ramos proximais cilíndricos; nós não circundados por coroa de tricomas. Folhas opostas; 

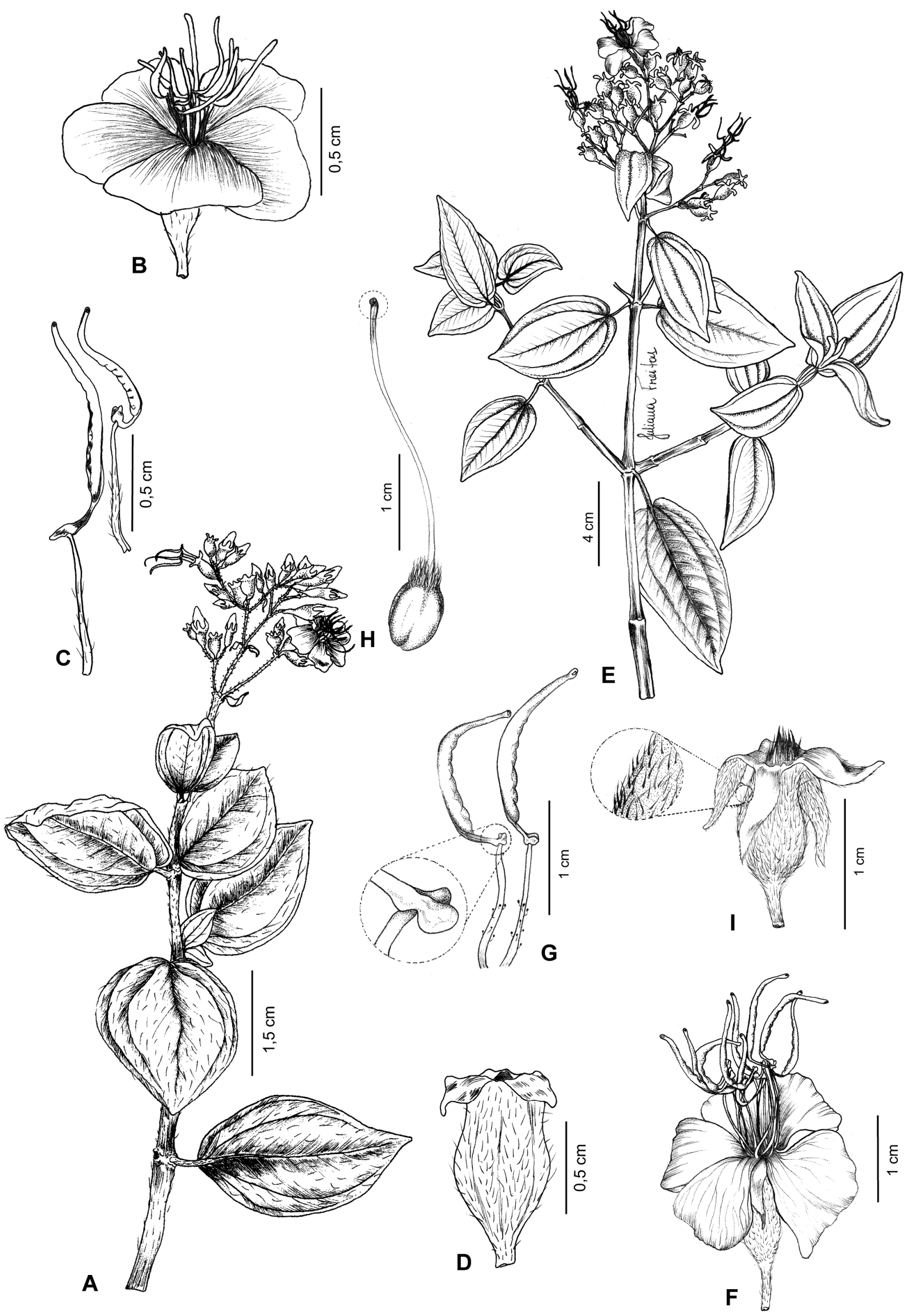

Figura 8. A-D. Tibouchina bradeana: A- ramo com botões, flores e frutos; B- flor; C- estames dos dois ciclos; D- fruto (Queiroz 415 ALCB). E-I. T. caatingae: E- ramo com flores e frutos; F- flor; G- estames dos dois ciclos com detalhe dos apêndices glabros; H- gineceu; I- fruto com sépalas persistentes e detalhe do indumento (Cardoso 533 HUEFS). 


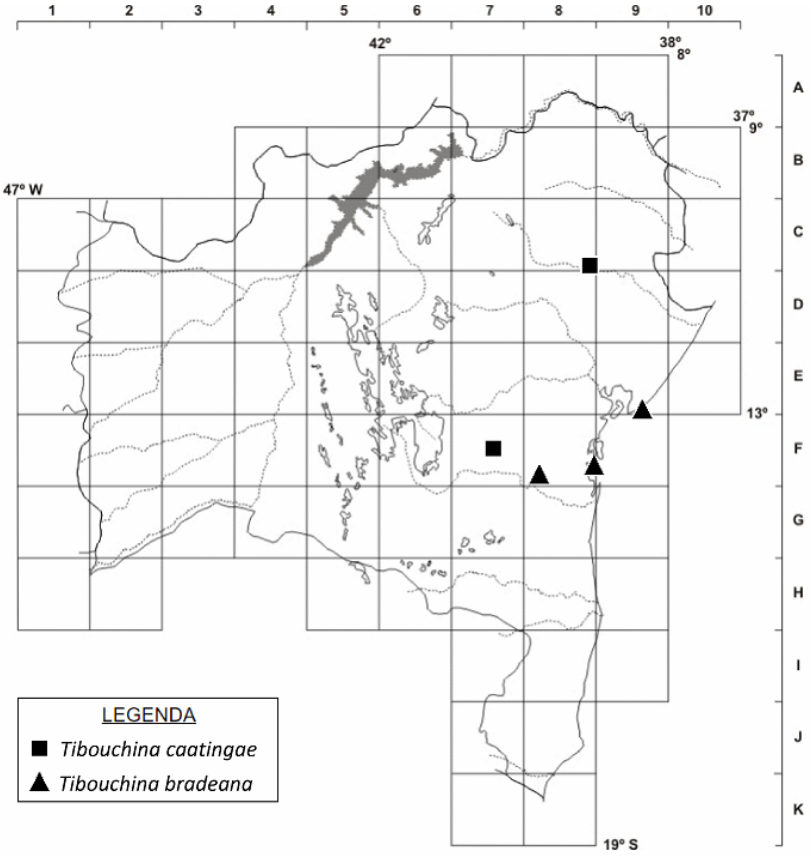

Figura 9. Mapa de distribuição geográfica de Tibouchina caatingae e T. bradeana no estado dda Bahia.

pecíolo 1-1,5 cm compr.; lâmina 5-7 × 3-4 cm, elíptica a oval, coriácea, ápice acuminado, base subcordada, margem inteira, não ciliada, plana, concolor, face adaxial estrigosa, tricomas simples, face abaxial serícea, tricomas simples, 5 nervuras basais. Inflorescências terminais, raque $2-7 \mathrm{~cm}$ compr., tricomas simples; bractéolas 0,5-1,2 × 0,3-0,5 cm, elíptico-lanceoladas, não involucrais, tricomas simples. Flores 5-meras; pedicelo ca. 0,3 cm compr.; hipanto 1$1,5 \times 0,3-0,5 \mathrm{~cm}$, oblongo, seríceo, tricomas simples, raro glândulas estipitadas; sépalas $0,6-0,8 \times$ ca. $0,2 \mathrm{~cm}$, decíduas, ápice agudo, não aristado; pétalas 1,6-2 × 1$1,5 \mathrm{~cm}$, obdeltoides, ápice truncado, púrpura. Estames 10, subisomorfos; filetes antissépalos 1-1,3 cm compr., os antipétalos ca. $1 \mathrm{~cm}$ compr., glândulas estipitadas em ambos os ciclos; conectivos prolongados abaixo das anteras, os antissépalos ca. 0,3 cm compr., os antipétalos ca. 0,2 cm compr., apêndices glabros em ambos os ciclos; anteras antissépalas ca. $1,5 \mathrm{~cm}$ compr., as antipétalas ca. $0,8 \mathrm{~cm}$ compr., lilás. Ovário hirsuto no terço apical; estilete curvo, glabro; estigma punctiforme. Cápsulas $1-1,2 \times 0,3-0,5 \mathrm{~cm}$, não costadas.

Endêmica do sudoeste da Bahia (Freitas et al. 2013; BFG 2015). C8, F7: caatinga. Coletada em estágio reprodutivo em maio, junho e outubro.

Material selecionado - Maracás, 1328'19"S, 40²4'29"W, 18 maio 2002, (fl., fr.), G.E.L. Macedo 23 (HUEFS); Quijingue, $10^{\circ} 55^{\prime} 20^{\prime \prime} \mathrm{S}, 39^{\circ} 04^{\prime} 59^{\prime \prime} \mathrm{W}, 15$ maio 2005 (bot.), D. Cardoso 533 (HUEFS).

Tibouchina caatingae é reconhecida pelas folhas ovais, adaxialmente estrigosas, abaxialmente seríceas, com tricomas simples, hipanto oblongo, com sépalas sem aristas. É morfologicamente semelhante a $T$. noblickii pelo indumento das folhas e filetes, porém esta última apresenta hipanto urceolado, sépalas aristadas e glândulas estipitadas nos apêndices estaminais e no estilete.

9. Tibouchina candolleana (Mart. ex DC.) Cogn. in Martius \& Eichler, Fl. Bras. 14(3): 339. 1885.

Figuras 1G, 10A-E e 11.

Arvoreta ou árvore 2-5 $\mathrm{m}$ alt.; ramos distais quadrangulares, não alados, escabros, tricomas dendríticos, ramos proximais subcilíndricos; nós não circundados por coroa de tricomas. Folhas opostas; pecíolo 0,5-1 cm compr.; lâmina $3-7 \times 1,2-2,5 \mathrm{~cm}$, elíptico-lanceolada, coriácea, ápice acuminado, base cuneada, margem inteira, não ciliada, revoluta, discolor, estrigosa em ambas as faces, tricomas dendríticos, não adpressos, não circundados por glândulas, 5 nervuras basais. Inflorescências axilares e terminais, raque 5-10 cm compr., tricomas dendríticos; bractéolas $0,8-1 \times$ ca. $0,2 \mathrm{~cm}$, lanceoladas, não involucrais, tricomas dendríticos. Flores 5-meras; pedicelo 0,3-0,6 cm compr.; hipanto ca. 0,5 × 0,3-0,5 $\mathrm{cm}$, campanulado, estrigoso, tricomas dendríticos; sépalas $0,3-0,5 \times 0,15-0,2 \mathrm{~cm}$, decíduas, ápice apiculado ou agudo, aristado; pétalas 1,2-2,5 × 1,4-1,8 $\mathrm{cm}$, obdeltoides, ápice truncado, lilás. Estames 10, dimorfos; filetes antissépalos ca. 1,3 cm compr., os antipétalos ca. 0,7 cm compr., glândulas estipitadas em ambos os ciclos; conectivos prolongados abaixo das anteras apenas no ciclo antissépalo, ca. 0,2 cm compr., apêndices com glândulas estipitadas em ambos os ciclos; anteras antissépalas ca. 0,9 cm compr., as antipétalas ca. 0,6 cm compr., púrpura ou creme. Ovário hirsuto no terço apical; estilete reto, com glândulas estipitadas; estigma truncado. Cápsulas ca. $0,8 \times 0,7 \mathrm{~cm}$, não costadas.

Endêmica do Brasil, no Distrito Federal, Goiás, Bahia, Minas Gerais e Paraná (Meyer et al. 2010). F5, F6: campos rupestres e áreas de transição entre cerrado e caatinga, na Chapada Diamantina e na Serra Geral. Coletada em estágio reprodutivo de julho a dezembro.

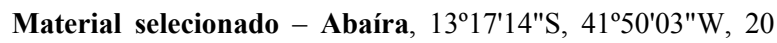
set. 1999 (bot., fr.), A.S. Conceição et al. 410 (ALCB, HUEFS); Caetité, 1352'17"S, 42³6'43"W, 28 ago. 1999 (bot., fl.), E. Melo

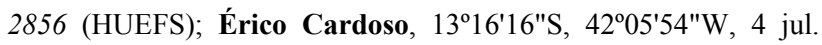
2001 (bot., fl.), T. Ribeiro 346 (CEPEC, HUEFS); Piatã, $13^{\circ} 17^{\prime} \mathrm{S}$, 41 ${ }^{\circ} 53^{\prime} \mathrm{W}, 6$ set. 1996 (fr.), R.M. Harley et al. 28318 (HUEFS, HUNEB); Rio de Contas, $13^{\circ} 32^{\prime} \mathrm{S}, 41^{\circ} 58^{\prime} \mathrm{W}, 23$ out. 1988 (fr.), R.M. Harley et al. 25306 (ALCB, CEPEC).

Tibouchina candolleana é caracterizada pela combinação de hábito arbóreo, folhas com 5 nervuras basais, glândulas estipitadas no estilete, filetes e nos apêndices estaminais. Assemelha-se em relação ao hábito, forma e dimensão foliares e ao fruto com $T$. francavillana e $T$. elegans, que diferem pelo estilete glabro e as folhas com nervuras suprabasais no par externo em $T$. francavillana e pelas folhas com 3 nervuras basais e filetes seríceos em $T$. elegans. 


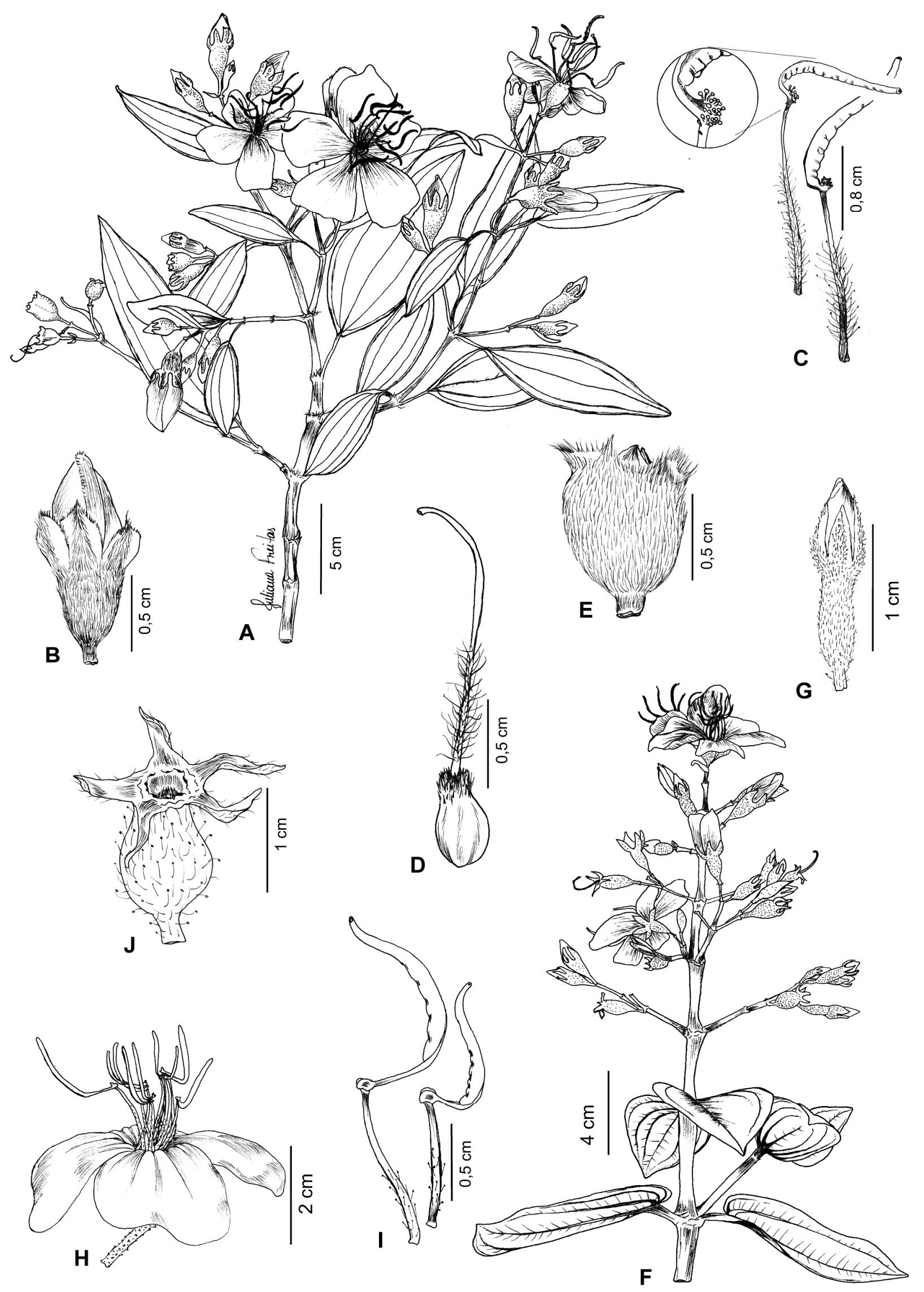

Figura 10. A-E. Tibouchina candolleana: A- ramo com botões, flores e frutos; B- botão floral; C- estames evidenciando as glândulas estipitadas nos apêndices; D- gineceu; E- fruto (Nunes 67 HUEFS). F-J. T. carvalhoi: F- ramo com botões e flores; G- botão floral; Hflor; I- estames dos dois ciclos; J- fruto (Freitas 545 HUEFS). 
10. Tibouchina carvalhoi Wurdack, Phytologia 53(2): 134. 1983.

Figuras $1 \mathrm{H}, 10 \mathrm{~F}-\mathrm{J}$ e 11.

Arbusto 1,5-2 m alt.; ramos distais subcilíndricos a quadrangulares, não alados, estrigosos, tricomas simples ou com glândulas estipitadas, ramos proximais cilíndricos; nós não circundados por coroa de tricomas. Folhas opostas; pecíolo 1-2,5 cm compr.; lâmina 4-7,7 × 3-4,3 cm, oval, coriácea, ápice agudo a acuminado, base obtusa a subcordada, margem inteira, não ciliada, plana, levemente discolor, face adaxial serícea, tricomas simples e glândulas estipitadas na base, face abaxial estrigosa, tricomas simples, 7 ou 9 nervuras basais ou suprabasais no último par. Inflorescências terminais, raque 10-20 cm compr., tricomas simples e/ou glândulas estipitadas; bractéolas ca. 1,2 ×0,3-0,5 cm, elíptico-lanceoladas, não involucrais, glândulas estipitadas. Flores 5-meras; pedicelo $0,3-0,7 \mathrm{~cm}$ compr.; hipanto $0,8-1 \times 0,3-0,5 \mathrm{~cm}$, oblongo, estrigoso, glândulas estipitadas; sépalas $0,5-0,7 \times$ ca. $0,3 \mathrm{~cm}$, geralmente persistentes, ápice agudo, não aristado; pétalas 1,5-2,3 × 1,2-1,5 cm, obovais, ápice arredondado, púrpura. Estames 10, subisomorfos; filetes antissépalos ca. 1,5 cm compr., os antipétalos ca. $1 \mathrm{~cm}$ compr., glândulas estipitadas em ambos os ciclos; conectivos prolongados abaixo das anteras, os antissépalos ca. $0,3 \mathrm{~cm}$ compr., os antipétalos ca. 0,2 $\mathrm{cm}$ compr., apêndices glabros em ambos os ciclos; anteras antissépalas ca. 1,4 cm compr., as antipétalas ca. $0,8 \mathrm{~cm}$ compr., lilás ou róseas. Ovário hirsuto no ápice; estilete curvo, glândulas estipitadas no terço basal; estigma truncado. Cápsulas 1-1,3 × 0,5-0,6 $\mathrm{cm}$, costadas ou não.

Endêmica da Bahia (BFG 2015), na porção central da Chapada Diamantina. E6, F6: campos rupestres.

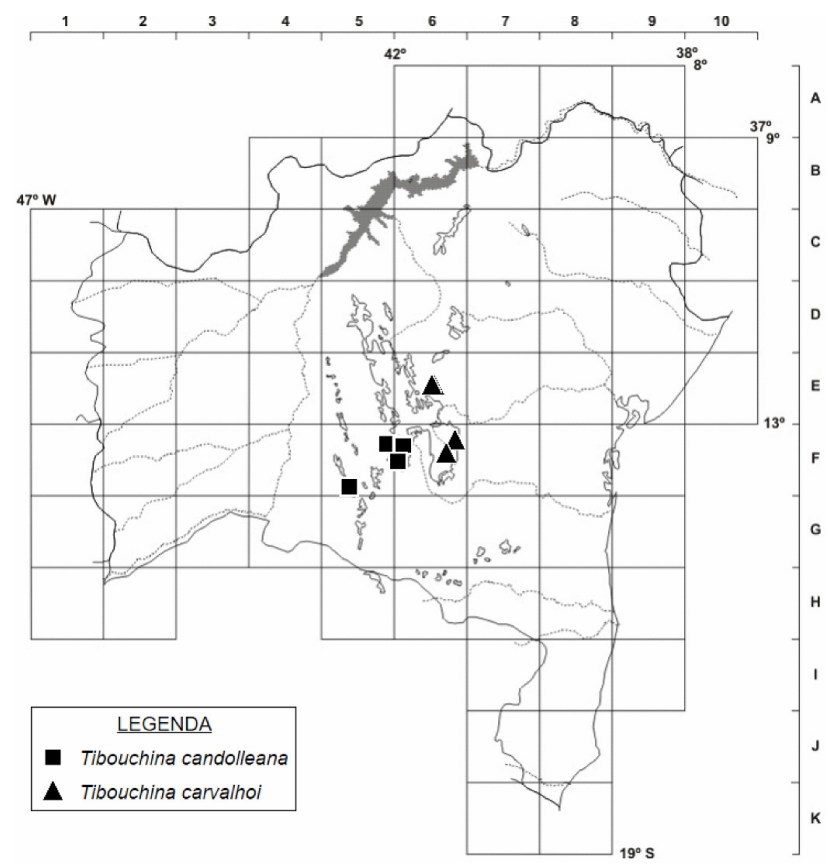

Figura 11. Mapa de distribuição geográfica de Tibouchina candolleana e T. carvalhoi no estado da Bahia.
Coletada em estágio reprodutivo de fevereiro a julho e em novembro.

Material selecionado - Lençóis, 12²7'35"S, 40²6'25"W, 29 jul. 1994 (bot., fl.), R. Orlandi et al. PCD 268 (ALCB, HUNEB); Mucugê, 12² $43^{\prime} \mathrm{S}, 41^{\circ} 30^{\prime} \mathrm{W}, 2$ jun. 2009 (bot., fr.), J.G. Freitas

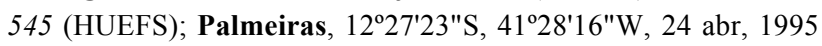
(bot., fl.), E. Melo et al. PCD 1778 (ALCB, CEPEC, HRB, HUEFS).

Tibouchina carvalhoi se distingue pelos ramos estrigosos, avermelhados, raque da inflorescência geralmente com glândulas estipitadas bem visíveis, lâmina foliar com glândulas estipitadas na base da face adaxial e nervuras secundárias bem proeminentes na face abaxial. É semelhante a um dos morfotipos de $T$. pereirae, principalmente em relação à forma, consistência e dimensão das folhas, ramificação das inflorescências e também pelos tricomas e glândulas nos ramos distais e hipanto. Distinguem-se pelo hipanto menos constrito no ápice, folhas com nervuras secundárias não ressaltadas na face abaxial e ausência de glândulas estipitadas na lâmina foliar em T. pereirae.

11. Tibouchina comosa J.G.Freitas, A.K.A.Santos \& R.P.Oliveira, Syst. Bot. 37(1): 190. 2012.

Figuras 1I, 12A-F e 13.

Arbusto 1-1,5 m alt.; ramos distais quadrangulares, não alados, denso-seríceos, tricomas simples, ramos proximais cilíndricos ou subcilíndricos; nós circundados por coroa de tricomas. Folhas opostas; pecíolo 1,5-2 cm compr.; lâmina $6-8,5 \times 3-4 \mathrm{~cm}$, oval-elíptica, coriácea, ápice acuminado, base obtusa a subcordada, margem inteira, não ciliada, plana, discolor, face adaxial estrigosa, tricomas simples, bulados na base, face abaxial serícea, tricomas simples, 5 nervuras basais. Inflorescências terminais, raque 5$10 \mathrm{~cm}$ compr., tricomas simples; bractéolas, $2-3 \times 0,8$ $1 \mathrm{~cm}$, lanceoladas, não involucrais, tricomas simples. Flores 5-meras; pedicelo 0,6-1 cm compr.; hipanto $0,8-1,2 \times 0,7-0,8 \mathrm{~cm}$, campanulado, seríceo, tricomas simples; sépalas $1-1,5 \times$ ca. $0,4 \mathrm{~cm}$, decíduas, ápice agudo, não aristado; pétalas 2,4-3 × 1,7-2 cm, obovais, ápice truncado, lilás. Estames 10, dimorfos; filetes antissépalos ca. 1,5 cm compr., os antipétalos ca. 0,8 cm compr., glabros em ambos os ciclos; conectivos prolongados abaixo das anteras, os antissépalos ca. 0,5 $\mathrm{cm}$ compr., os antipétalos ca. 0,2 cm compr., glabros em ambos os ciclos; anteras antissépalas ca. $1,3 \mathrm{~cm}$ compr., as antipétalas ca. $1 \mathrm{~cm}$ compr., lilás. Ovário hirsuto na porção apical; estilete curvo no ápice, glabro; estigma punctiforme. Cápsulas 1-1,4 × 0,9-1 $\mathrm{cm}$, não costadas.

Endêmica da Bahia, na Chapada Diamantina (Freitas et al. 2012; BFG 2015). E6: campos rupestres. Coletada com flores e frutos em abril.

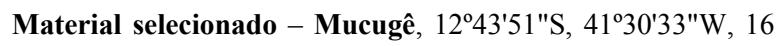
abr. 2005 (fl., fr.), A.A. Conceição 1273 (HUEFS).

Tibouchina comosa distingue-se das demais espécies do gênero na Bahia por possuir indumento 


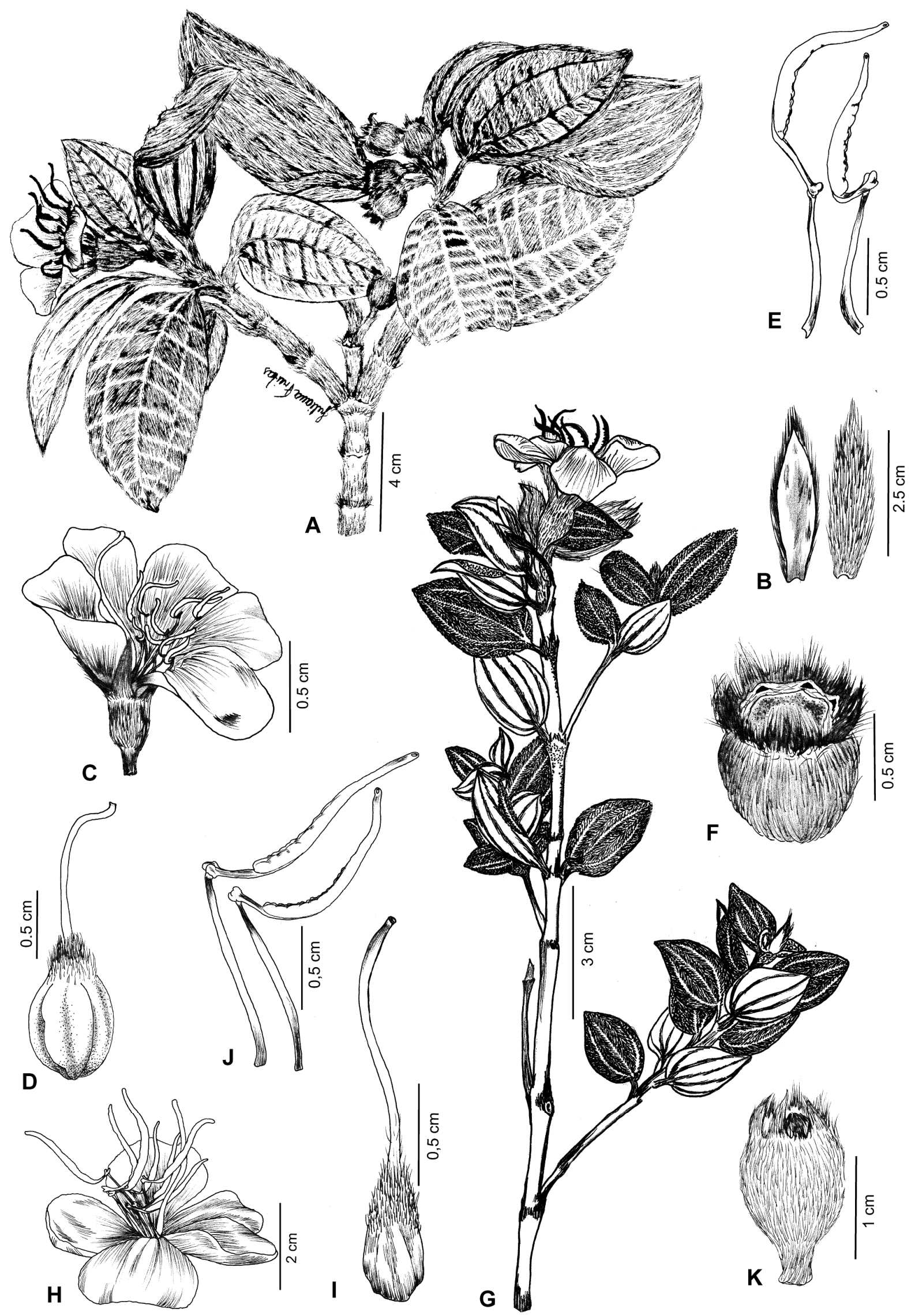

Figura 12. A-F. Tibouchina comosa: A- ramo com flores e frutos; B- bractéola em face interna e externa; C- flor; D- gineceu; E- estames dos dois ciclos; F- fruto (Conceição 1273 HUEFS). G-K. T. crassiramis: G- ramo com botão e flor; H- flor; I- gineceu; J- estames dos dois ciclos; K- fruto (Barreto 366 HUEFS). 
denso-seríceo, com tricomas simples em toda a parte vegetativa (exceto na face adaxial das folhas, que é estrigosa, com tricomas simples, bulados na base), ramos proximais com córtex decorticante e bractéolas com 2-3 cm de comprimento, precocemente decíduas.

12. Tibouchina crassiramis Cogn., Bot. Jahrb. Syst. 21: 446. 1895.

Figuras 1J, 12G-K e 13.

Arbusto 1-1,5 $\mathrm{m}$ alt.; ramos distais subcilíndricos, não alados, seríceos, tricomas simples, ramos proximais cilíndricos; nós não circundados por coroa de tricomas hirsutos. Folhas opostas; pecíolo 0,3-0,8 cm compr.; lâmina 1,3-3 × 0,8-2 cm, oval, coriácea, ápice obtuso, base obtusa a cordada, margem inteira, não ciliada, plana, discolor, face adaxial escabra, tricomas simples e bulados na base, face abaxial serícea, tricomas simples, 5 ou 7 nervuras basais. Inflorescências terminais, raque 3-5 cm compr., tricomas simples; bractéolas 1-1,6 $\times$ 0,4-0,5 cm, lanceoladas, não involucrais, tricomas simples. Flores 5-meras; pedicelo 0,2-0,4 cm compr.; hipanto $1-1,3 \times 0,5-0,6 \mathrm{~cm}$, urceolado, seríceo, tricomas simples; sépalas 0,7-1,2 × 0,3-0,6 cm, decíduas, ápice agudo, não aristado; pétalas 2-2,5 × 1,2-1,5 cm, obdeltoides, ápice arredondado, lilás ou róseas. Estames 10, subisomorfos; filetes antissépalos ca. 1,4 cm compr., os antipétalos ca. $1 \mathrm{~cm}$ compr., glabros em ambos os ciclos; conectivos prolongados abaixo das anteras, os antissépalos ca. 0,3 cm compr., os antipétalos ca. 0,2 cm compr., apêndices glabros em ambos os ciclos; anteras antissépalas ca. 1,4 cm compr., as antipétalas ca. $0,8 \mathrm{~cm}$ compr., lilás ou brancas. Ovário hirsuto na metade apical; estilete reto, tricomas simples na base; estigma punctiforme. Cápsulas $1-1,2 \times 0,7-0,9 \mathrm{~cm}$, não costadas.

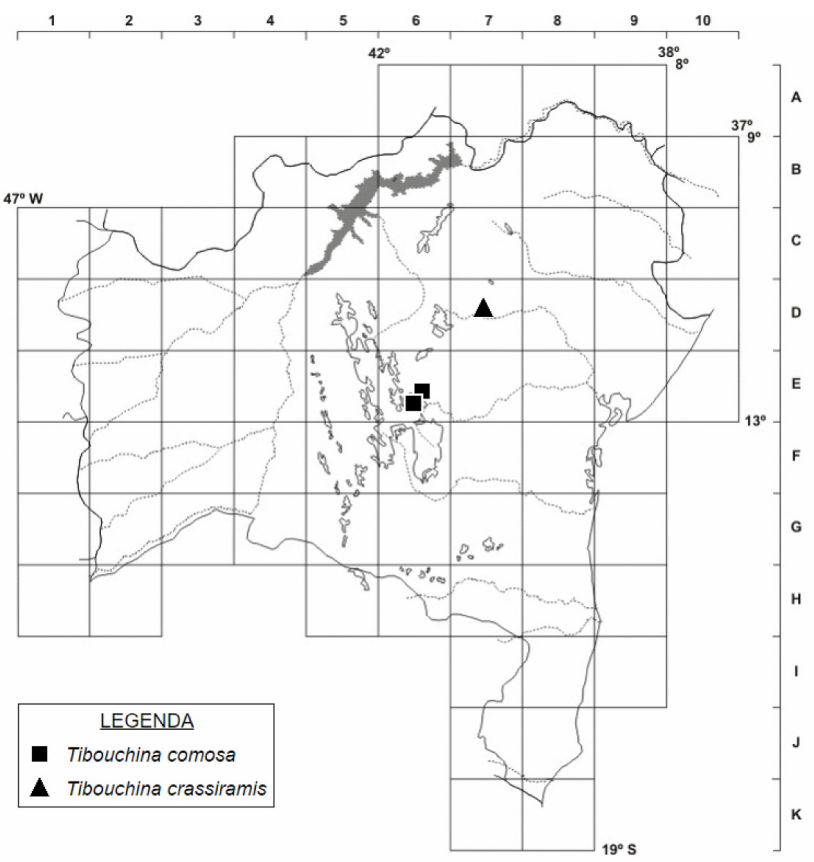

Figura 13. Mapa de distribuição geográfica de Tibouchina comosa e T. crassiramis no estado da Bahia.
Endêmica do Brasil, ocorre em Goiás (Campos 2005; BFG 2015), sendo aqui citada pela primeira vez para a Bahia. D7: campo rupestre, sobre topo de serra, em fendas de rochas, nos limites setentrionais da Chapada Diamantina. Coletada com flores e frutos em outubro.

Material examinado - Senhor do Bonfim, 11 $23^{\prime} 32^{\prime \prime} \mathrm{S}$, 40³2'17"W, 26 out. 2006 (bot., fl., fr.), V. Barreto 366 (HUEFS, HUNEB).

Tibouchina crassiramis é reconhecida pelos ramos distais seríceos, folhas ovais, adaxialmente escabras, com tricomas simples de base bulada, e face abaxial das folhas, hipanto e sépalas seríceos. Os espécimes observados da Bahia são semelhantes a $T$. oreophila, pelo hábito e principalmente pela forma das folhas e indumento da face adaxial, mas em $T$. oreophila, os ramos distais são escabros, ambas as faces da lâmina foliar possuem tricomas dendríticos e o hipanto é campanulado e estrigoso.

13. Tibouchina elegans (Gardner) Cogn. in Martius \& Eichler, Fl. Bras. 14(3): 323. 1885.

Figuras 1K, 14A-E e 15.

Arvoreta ou árvore 4-10 m alt.; ramos distais subcilíndricos a quadrangulares, não alados, tomentosos, tricomas simples, ramos proximais cilíndricos; nós não circundados por coroa de tricomas. Folhas opostas; pecíolo 1-1,5 cm compr.; lâmina 3-7 $\times 2-3 \mathrm{~cm}$, oval-elíptica, coriácea, ápice agudo, base acuminada, margem inteira, não ciliada, plana, discolor, escabra em ambas as faces, tricomas simples, 3 nervuras basais. Inflorescências axilares e terminais, raque $8-18 \mathrm{~cm}$ compr., tricomas simples; bractéolas 1$1,2 \times 0,3-0,4 \mathrm{~cm}$, elíptico-lanceoladas, não involucrais, tricomas simples. Flores (5)6(7)-meras; pedicelo 0,3$0,5 \mathrm{~cm}$ compr.; hipanto ca. $0,5 \times 0,3-0,5 \mathrm{~cm}$, campanulado, estrigoso, tricomas simples; sépalas ca. 0,3-0,7 × 0,3 cm, decíduas, ápice arredondado, aristado; pétalas $2,2-2,5 \times 1,5-1,8 \mathrm{~cm}$, obdeltoides, ápice truncado, róseas ou lilás. Estames (10)12(14), subisomorfos; filetes antissépalos ca. 1,5 cm compr., os antipétalos ca. 0,9 cm compr., seríceos, tricomas simples em ambos os ciclos; conectivos prolongados abaixo das anteras, os antissépalos ca. 0,4 cm compr., os antipétalos ca. $0,1 \mathrm{~cm}$ compr., apêndices com glândulas estipitadas em ambos os ciclos; anteras antissépalas ca. 1,2 cm compr., as antipétalas ca. 0,9 $\mathrm{cm}$ compr., róseas ou esbranquiçadas, vináceas após antese. Ovário hirsuto no ápice; estilete curvo no ápice, tricomas simples na metade basal; estigma punctiforme. Cápsulas $0,7-0,9 \times 0,6-0,8 \mathrm{~cm}$, não costadas.

Endêmica do Brasil, ocorre no Rio de Janeiro (BFG 2015), sendo citada aqui pela primeira vez para a Bahia. E9, F8, G8, I8: floresta ombrófila, no litoral. Foi coletada em estágio reprodutivo de dezembro a junho.

Material selecionado - Camaçari, $12^{\circ} 29^{\prime} 35^{\prime \prime} \mathrm{S}, 38^{\circ} 18^{\prime} 47^{\prime \prime} \mathrm{W}$, 23 nov. 1982 (fl.), L.R. Noblick 2153 (HUEFS); Canavieiras, 
15039'S, 3857'W, 23 fev. 1970 (fl., fr.), J.A. Jesus 601 (CEPEC); Igrapiúna, $13^{\circ} 49^{\prime} \mathrm{S}, 39^{\circ} 08^{\prime} \mathrm{W}, 19$ dez. 2003 (fr.), D.M. Loureiro et al. 768 (ALCB, HUNEB); Ilhéus, $14^{\circ} 53^{\prime} \mathrm{S}, 39^{\circ} 02^{\prime} \mathrm{W} 24$ fev. 1984, L.A. Matos-Silva et al. 1718 (CEPEC, HUEFS, HRB); Ituberá, $13^{\circ} 43^{\prime} \mathrm{S}, 39^{\circ} 08^{\prime} \mathrm{W}, 3$ set. 2001 (fl.), M.L. Guedes et al. 9447 (ALCB); Salvador, $12^{\circ} 35^{\prime} \mathrm{S}, 38^{\circ} 24^{\prime} \mathrm{W}, 18 \mathrm{dez} .2004$ (fl., fr.), M.L. Guedes et al. 11220 (ALCB); Santa Cruz Cabrália, 161' S, $39^{\circ} 01^{\prime} \mathrm{W}, 20$ jun. 1999 (fr.), S.S. Lima et al. 82 (ALCB, CEPEC, HUNEB); Una, $15^{\circ} 06^{\prime} \mathrm{S}, 39^{\circ} 06^{\prime} \mathrm{W}, 17$ nov. 1980 (est.), A. Rylands \& J.L. Hage 186 (CEPEC).

Tibouchina elegans apresenta folhas ovalelípticas, 3-nervadas, hipanto campanulado, filetes e estilete seríceos. Em sua descrição original (Cogniaux 1885), um material proveniente da Bahia foi citado como parte da coleção-tipo. Muitos materiais foram observados apresentando os mesmos caracteres aceitos para essa espécie (com exceção apenas do indumento, mais denso nas folhas e hipanto dos espécimes do RJ), os quais foram aqui reconhecidos como T. elegans. Vários desses materiais estavam identificados nos herbário como $T$. francavillana, a qual distingue-se, entretanto, pelas folhas com 5 nervuras e estilete glabro, além do indumento foliar formado por tricomas adpressos circundados por glândulas pediceladas, completamente distinto de $T$. elegans (Freitas 2011).

14. Tibouchina fissinervia (Schrank \& Mart. ex DC.) Cogn. in Martius \& Eichler, Fl. Bras. 14(3): 343. 1885 .

Figuras 1L, 14F-K e 15.

Árvore 5-20 m alt.; ramos distais quadrangulares, geralmente subalados, estrigosos, tricomas dendríticos, ramos proximais cilíndricos ou subcilíndricos; nós circundados por coroa de tricomas. Folhas opostas; pecíolo 1-1,5 cm compr.; lâmina 5-9,5 × 1,7-2,9 cm, elíptica, coriácea, ápice agudo, base cuneada, margem inteira, não ciliada, plana, discolor, face adaxial escabra, tricomas simples, face abaxial estrigosa, tricomas dendríticos, 5 nervuras suprabasais no último par. Inflorescências terminais, raque $10-16 \mathrm{~cm}$ compr., tricomas dendríticos; bractéolas 0,9-1,3 × 0,3$0,5 \mathrm{~cm}$, elíptico-lanceoladas, não involucrais, tricomas dendríticos. Flores 5-meras; pedicelo 0,5-1 cm compr.; hipanto 0,6-1 $\times$ 0,4-0,6 cm, urceolado, estrigoso, tricomas dendríticos; sépalas $0,6-1 \times 0,3-0,5$ cm, decíduas, ápice agudo, não aristado; pétalas 2,5-3 $\times$ 1,3-1,8 cm, obovais, ápice arredondado, lilás. Estames 10, dimorfos; filetes antissépalos ca. 1,6 cm compr., os antipétalos ca. $1 \mathrm{~cm}$ compr., tricomas simples, densos em ambos os ciclos; conectivos prolongados abaixo das anteras, os antissépalos ca. 0,3 cm compr., os antipétalos ca. 0,1 cm compr., apêndices glabros em ambos os ciclos; anteras antissépalas ca. $1,5 \mathrm{~cm}$ compr., as antipétalas ca. $0,7 \mathrm{~cm}$ compr., róseas. Ovário hirsuto no ápice; estilete reto, tricomas simples ou glândulas estipitadas na metade basal; estigma punctiforme. Cápsulas $0,8-1 \times 0,7-0,9 \mathrm{~cm}$, não costadas.
Endêmica do Brasil, ocorre na Bahia, Espírito Santo, Minas Gerais e Rio de Janeiro (BFG 2015). C7, D7, E6, E8, F6, F8, G8, H8, I8: floresta ombrófila, mata estacional ou mata ciliar, na Chapada Diamantina, piemonte da diamantina, recôncavo sul, litoral sul e extremo sul do estado. Coletada em estágio reprodutivo de fevereiro a julho e em novembro.

Material selecionado - Abaíra, $13^{\circ} 17^{\prime} \mathrm{S}, 41^{\circ} 52^{\prime} \mathrm{W}, 3$ mar. 1992 (bot., fl.), B. Stannard et al. 51738 (CEPEC, HUEFS); Almadina, 14²4'13"S, 39³6'09"W, 19 mar. 2006 (fl.), J.L. Paixão et al. 486 (CEPEC, HUEFS); Arataca, 1510'25"S, 39'20'30"W, 12 fev. 2005 (fl.), J.G. Jardim 4413 (HUEFS); Amargosa, 1310'20"S, 39 09'34"W, 25 jan. 2007 (fl.), D. Cardoso 1605 (HUEFS); Andaraí, 12 48'23"S, 41 $20^{\circ} 46^{\prime \prime} \mathrm{W}, 10$ maio 2003 (fl.), A.B. Xavier et al. s.n. (ALCB 61847); Barra da Estiva, 13⒊'35"S, 41 ${ }^{\circ} 20^{\prime} 02^{\prime \prime W}, 16$ fev. 1997 (bot., fl.), T.R. Santos et al. PCD 5782 (ALCB, HRB); Barro Preto, 14 $46^{\prime} 13^{\prime \prime S}, 39^{\circ} 12^{\prime} 10^{\prime \prime} \mathrm{W}, 7$ fev. 2005 (bot., fl.), A.M. Amorim et al. 4787 (CEPEC); Bonito, 1201'37"S, 41 ${ }^{\circ} 13^{\prime} 57^{\prime \prime} \mathrm{W}, 12$ mar. 2002 (bot., fl.), W.W. Thomas et al. 12948 (CEPEC); Castro Alves, 12 $51^{\prime} 11^{\prime \prime S}, 39^{\circ} 28^{\prime} 19^{\prime \prime} \mathrm{W}, 27$ maio 1987 (fl.), L.P. Queiroz et al. 1577 (ALCB, CEPEC, HUEFS); Camacan, $15^{\circ} 23^{\prime} 30^{\prime \prime S}, 39^{\circ} 33^{\prime} 55^{\prime \prime W}, 9$ jul. 2005 (fr.), A.M. Amorim et al. 5161 (CEPEC); Ibicoara, 132' $\mathrm{S}, 41^{\circ} 17^{\prime} \mathrm{W}, 11$ mar. 1999 (fl., fr.), L.A.

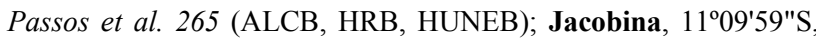
40³0'23"W, 2 maio 2001 (bot., f1.), F.R. Nonato et al. 880 (ALCB, CEPEC, HRB, HUEFS); Lençóis, $12^{\circ} 35^{\prime} \mathrm{S}, 41^{\circ} 32^{\prime} \mathrm{W}, 17$ mar. 1988 (bot.), M.C. Ferreira et al. 82 (CEPEC, HRB); Miguel Calmon, $1^{\circ} 22^{\prime} 50^{\prime \prime S}, 40^{\circ} 32^{\prime} 47^{\prime \prime W}, 11$ mar. 2006 (bot., fl.), V. Barreto 196 (HUEFS); Mucugê, 12²59'18"S, 41'20'27"W, 13 mar. 2004 (bot., fl.), N. Roque 1034 (ALCB, HUNEB); Palmeiras, 12²7'09"S, 41 $28^{\prime} 30^{\prime \prime} \mathrm{W}, 25$ maio 2009 (fr.), E.P. Queiroz 2781 (HRB); Piatã,

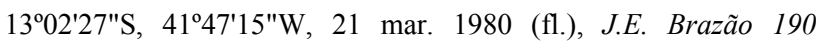
(HRB); Pindobaçu, 100' $40^{\prime} 8^{\prime S}, 40^{\circ} 19^{\prime} 47^{\prime \prime} \mathrm{W}, 9$ fev. 2005 (fl., fr.), L.A. Sousa 252 (HUEFS); Rio de Contas, 1315'43"S, 41 ${ }^{\circ} 55^{\prime} 29^{\prime \prime} \mathrm{W}$, 1 abr. 2000 (est.), F.H.F. Nascimento 370 (HUEFS); Santa Terezinha, $12^{\circ} 52^{\prime} 05^{\prime \prime} \mathrm{S}, 39^{\circ} 28^{\prime} 47^{\prime \prime} \mathrm{W}, 4$ mar. 2001 (fl., fr.), L.P. Queiroz 6494 (HUEFS); Saúde, 1054'02'S, 40²6'55"W, 7 abr. 1996 (fl.), M.L.S. Guedes PCD 2906 (ALCB, CEPEC, HUEFS); Utinga, 12³3'38"S, 4123'29"W, 10 mar. 1996 (fl.), E. Woodgyer et al. PCD 2216 (HRB).

Tibouchina fissinervia é reconhecida pelos ramos quadrangulares subalados, face abaxial das folhas, hipanto e sépalas com indumento estrigoso e tricomas dendríticos. É semelhante a $T$. granulosa pelo hábito, forma das folhas e coloração das flores, distinguindose pela face adaxial das folhas com tricomas adpressos em forma de Y e base espessada, filetes e estiletes seríceos, com tricomas simples em T. granulosa.

15. Tibouchina francavillana Cogn. in Martius \& Eichler, Fl. Bras. 14(3): 314. 1885.

Figuras 1M, 16A-E e 17.

Árvore 6-8 m alt.; ramos distais subcilíndricos a quadrangulares, não alados, estrigosos, tricomas simples, ramos proximais cilíndricos; nós circundados por coroa de tricomas. Folhas opostas; pecíolo 1-1,5 cm compr.; lâmina $6,8-12 \times 2,5-4 \mathrm{~cm}$, elíptica, coriácea, ápice agudo, base acuminada, margem inteira, não ciliada, levemente revoluta, discolor, 

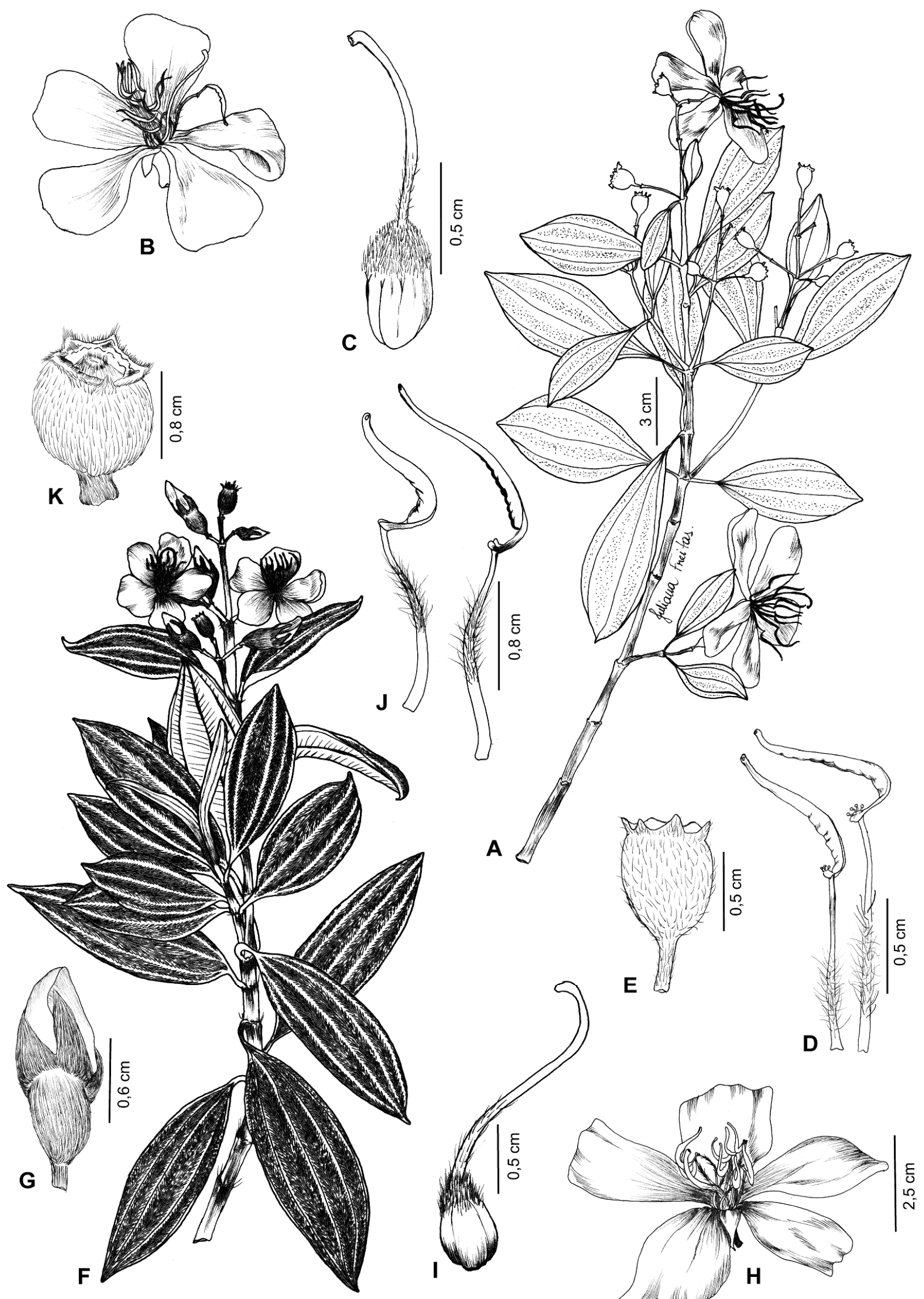


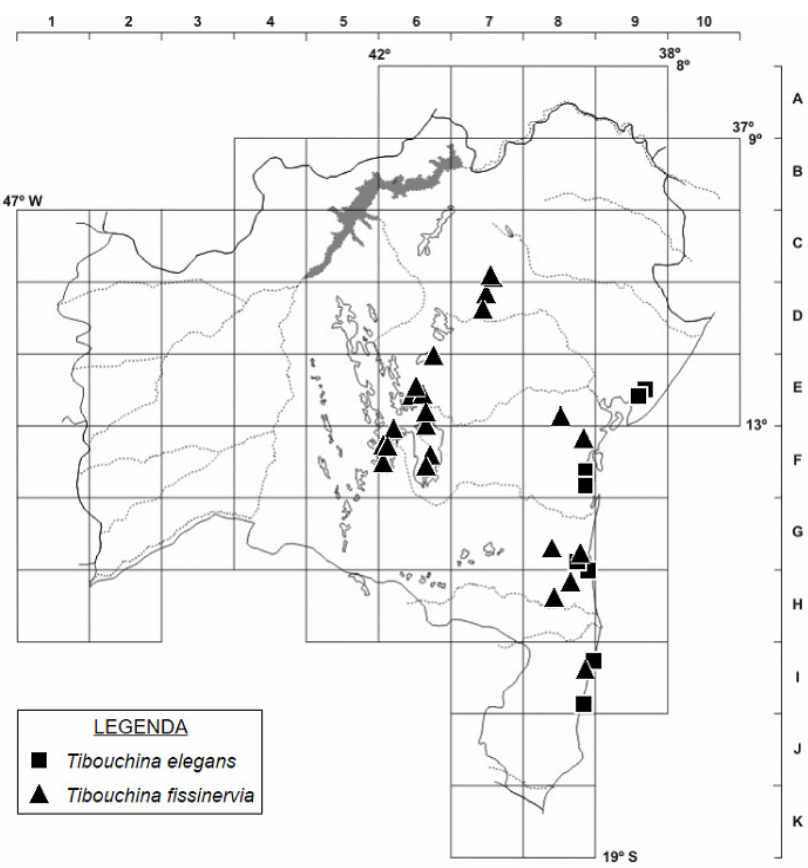

Figura 15. Mapa de distribuição geográfica de Tibouchina elegans e T. fissinervia no estado da Bahia.

escabra em ambas as faces, tricomas adpressos, circundados por glândulas pediceladas, 5 nervuras suprabasais no último par. Inflorescências terminais, raque $8-18 \mathrm{~cm}$ compr., tricomas simples; bractéolas $0,5-0,8 \times 0,3 \mathrm{~cm}$, lanceoladas, não involucrais, tricomas simples. Flores (5)6(-8)-meras; pedicelo 0,3-0,5 cm compr.; hipanto ca. $0,5 \times 0,3-0,5 \mathrm{~cm}$, campanulado, estrigoso, tricomas simples; sépalas $0,2-0,4 \times$ ca. 0,2 $\mathrm{cm}$, decíduas, ápice arredondado, não aristado; pétalas 2,2-2,5 × 1,5-1,8 cm, obdeltoides, ápice truncado, lilás ou púrpura. Estames (10)12, subisomorfos; filetes antissépalos ca. $1,5 \mathrm{~cm}$ compr., os antipétalos ca. $0,9 \mathrm{~cm}$ compr., tricomas simples em ambos os ciclos; conectivos prolongados abaixo das anteras, os antissépalos ca. 0,3 cm compr., os antipétalos ca. $0,1 \mathrm{~cm}$ compr., apêndices com glândulas estipitadas em ambos os ciclos; anteras antissépalas ca. 1,2 cm compr., as antipétalas ca. 0,9 cm compr., lilás. Ovário hirsuto no terço apical; estilete reto, glabro; estigma punctiforme. Cápsulas $0,7-0,9 \times 0,6-0,8 \mathrm{~cm}$, não costadas.

Endêmica do Brasil, ocorre em Sergipe e Bahia (BFG 2015). E7, E9, G8, H8, I8: floresta ombrófila, no litoral, Serra Geral e Recôncavo Sul. Coletada em estágio reprodutivo em quase todos os meses do ano.

Material selecionado - Alagoinhas, $12^{\circ} 08^{\prime} \mathrm{S}, 38^{\circ} 26^{\prime} \mathrm{W}, 5 \mathrm{dez}$. 2000 (fl.), N.G. Jesus 433 (HUESC, HUNEB); Belmonte, 1600'S, $39^{\circ} 15^{\prime} \mathrm{W}, 2$ abr. 2003 (fr.), P. Fiaschi et al. 1440 (CEPEC); Entre Rios, 1244'55"S, 40¹2'00"W, 8 dez. 1996 (fl., fr.) N.G. Jesus et al. $P L 0025$ (ALCB, HUESC, HUNEB); Ilhéus, $15^{\circ} 00^{\prime} \mathrm{S}, 39^{\circ} 04^{\prime} \mathrm{W}, 30$ jan. 1992 (bot., fl.), W.W. Thomas et al. 8978 (CEPEC); Mata de São João, 12³0'50"S, 38²17'25"W, 11 ago. 1994 (bot.), M.L. Guedes s.n. (ALCB 026954); Ituaçu, $13^{\circ} 48^{\prime} \mathrm{S}, 41^{\circ} 17^{\prime} \mathrm{W}, 31$ maio 1990 (f1.), E.P.G. Oliveira s.n. (ALCB 023098); Salvador,

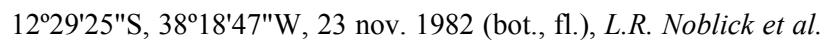
2153 (HRB); Santo Amaro, 12³2'45"S, 3848'09"W, 22 nov. 1986 (fl., fr.), L.P. Queiroz 1372 (HUEFS); São Sebastião do Passé, $12^{\circ} 30^{\prime} \mathrm{S}, 38^{\circ} 17^{\prime} \mathrm{W}, 27$ set. 2009, J.G. Freitas 557 (HUEFS); Una, $15^{\circ} 09^{\prime} 35^{\prime \prime} \mathrm{S}, 39^{\circ} 03^{\prime} 17^{\prime \prime} \mathrm{W}, 7$ jan. 2006 (fl.), A.M. Amorim et al. 5486 (CEPEC); Uruçuca, $14^{\circ} 23^{\prime} 12^{\prime \prime} \mathrm{S}, 39^{\circ} 04^{\prime} 45^{\prime \prime} \mathrm{W}, 5$ abr. 2004 (fr.), $P$. Fiaschi et al. 2255 (CEPEC).

Tibouchina francavillana é reconhecida pelas folhas escabras, com os tricomas circundados por glândulas pediceladas, 5 nervuras principais, com o último par suprabasal e estilete glabro. Na Bahia, é muito comum a existência de indivíduos com número de peças florais variado, podendo ocorrer flores até 8meras, mas geralmente são 6-meras. Morfologicamente, é semelhante a T. elegans, devido ao hábito, coloração das flores e variação no "número-padrão" de peças florais, porém, diferem pelas folhas com 3 nervuras basais e indumento escabro em ambas as faces, com tricomas simples, e filetes seríceos em $T$. elegans.

16. Tibouchina granulosa (Desr.) Cogn. in Martius \& Eichler, Fl. Bras. 14(3): 340. 1885.

Figuras $1 \mathrm{~N}, 16 \mathrm{~F}-\mathrm{J}$ e 17.

Árvore 8-10 m alt.; ramos distais quadrangulares, alados, estrigosos, tricomas parcialmente adpressos, ramos proximais cilíndricos; nós circundados por coroa de tricomas. Folhas opostas; pecíolo 1,5-3 cm compr.; lâmina 5-16 × 3-6,5 cm, elíptica, coriácea, ápice agudo a acuminado, base obtusa, margem inteira, não ciliada, plana, discolor, face adaxial escabra, tricomas adpressos com base espessada em forma de $\mathrm{Y}$, face abaxial estrigosa, tricomas dendríticos, 5 nervuras suprabasais no último par. Inflorescências terminais, raque $10-15 \mathrm{~cm}$ compr., tricomas dendríticos; bractéolas $0,5-1,3 \times 0,2-0,6 \mathrm{~cm}$, elípticas, não involucrais, tricomas dendríticos. Flores 5-meras; pedicelo até $1 \mathrm{~cm}$ compr.; hipanto $0,5-1 \times 0,7-1,2 \mathrm{~cm}$, campanulado, estrigoso, tricomas dendríticos; sépalas 0,6-1 × 0,2-0,4 cm, decíduas, ápice acuminado, não aristado; pétalas 1,5-3 × 1,2-1,5 cm, obdeltoides, ápice agudo, róseas a púrpura. Estames 10, dimorfos; filetes antissépalos ca. $2 \mathrm{~cm}$ compr., os antipétalos ca. $1 \mathrm{~cm}$ compr., tricomas simples em ambos os ciclos; conectivos prolongados abaixo das anteras, os antissépalos ca. 0,4 cm compr., os antipétalos ca. 0,2 cm compr., apêndices glabros em ambos os ciclos; anteras antissépalas ca. 1,4 cm compr., as antipétalas ca. 0,9 cm compr., lilás ou róseas. Ovário hirsuto no terço apical, densamente no ápice; estilete curvo no ápice, tricomas simples, densos; estigma truncado. Cápsulas $0,8-1 \times 0,8-1 \mathrm{~cm}$, não costadas.

Endêmica do Brasil, ocorre no Rio de Janeiro e São Paulo (BFG 2015), sendo citada aqui pela primeira vez para a Bahia. D6, E9, F8: áreas florestais, na Chapada Diamantina, litoral sul e região metropolitana de Salvador. Coletada em estágio reprodutivo de abril a novembro.

Material selecionado - Camaçari, $12^{\circ} 46^{\prime} \mathrm{S}, 38^{\circ} 19^{\prime \prime} \mathrm{W}, 10$ nov. 2009 (bot., fl.), J.G. Freitas 644 (HUEFS); Gandu, 1356'39"S, 39²9'23"W, 2 ago. 2009, J.G. Freitas 551 (HUEFS); Utinga, $12^{\circ} 00^{\prime} \mathrm{S}, 41^{\circ} 12^{\prime} \mathrm{W}, 10$ abr. 1986 (fl.), H.P. Bautista 1111 (HRB). 


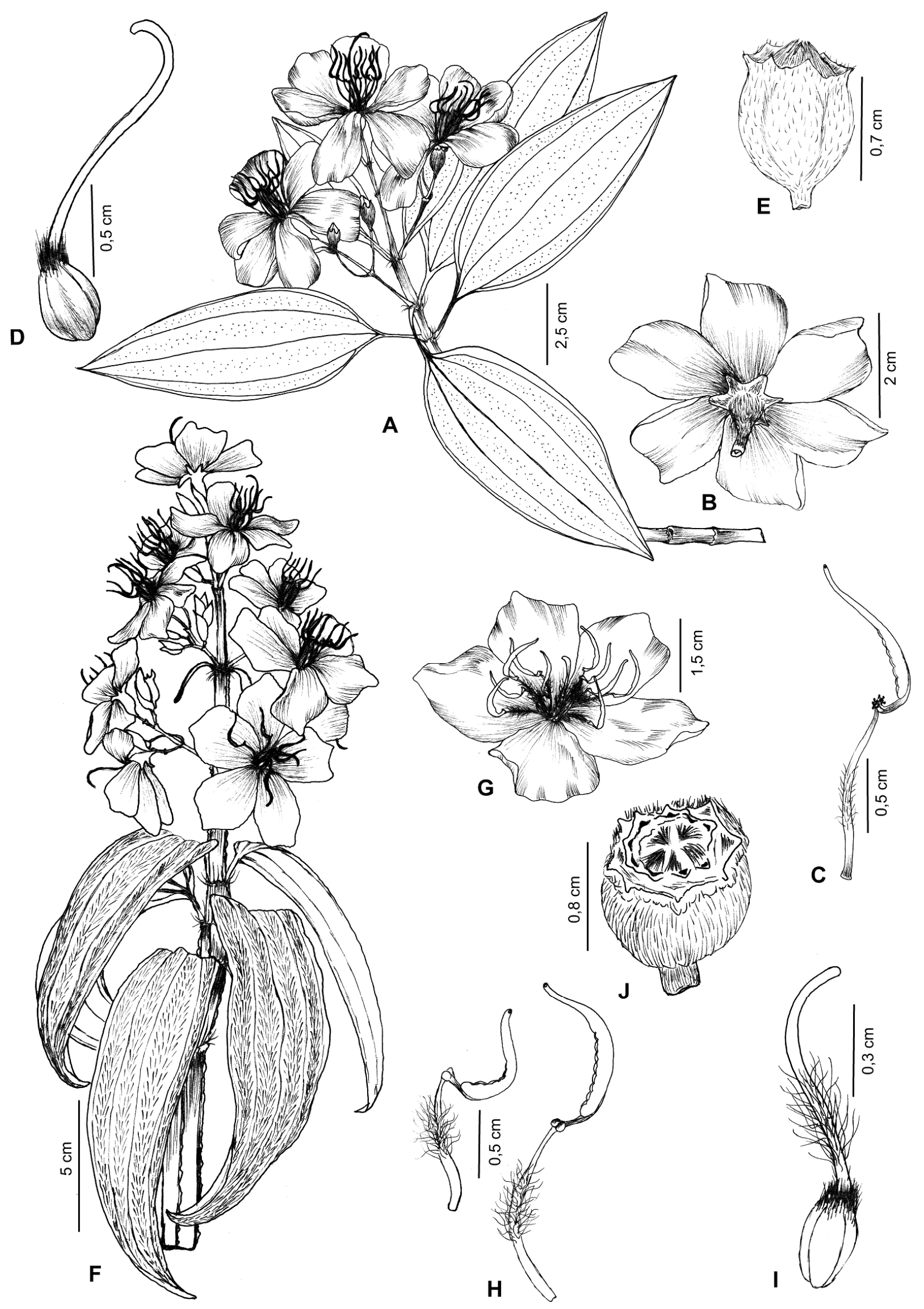

Figura 16. A-E. Tibouchina francavillana: A- ramo com flores; B- flor; C- estame; D- gineceu; E- fruto (Freitas 557 HUEFS). F-J. T. granulosa: F- ramo com flores; G- flor; H- estames dos dois ciclos; I- gineceu; J- fruto (Freitas 551 HUEFS). 


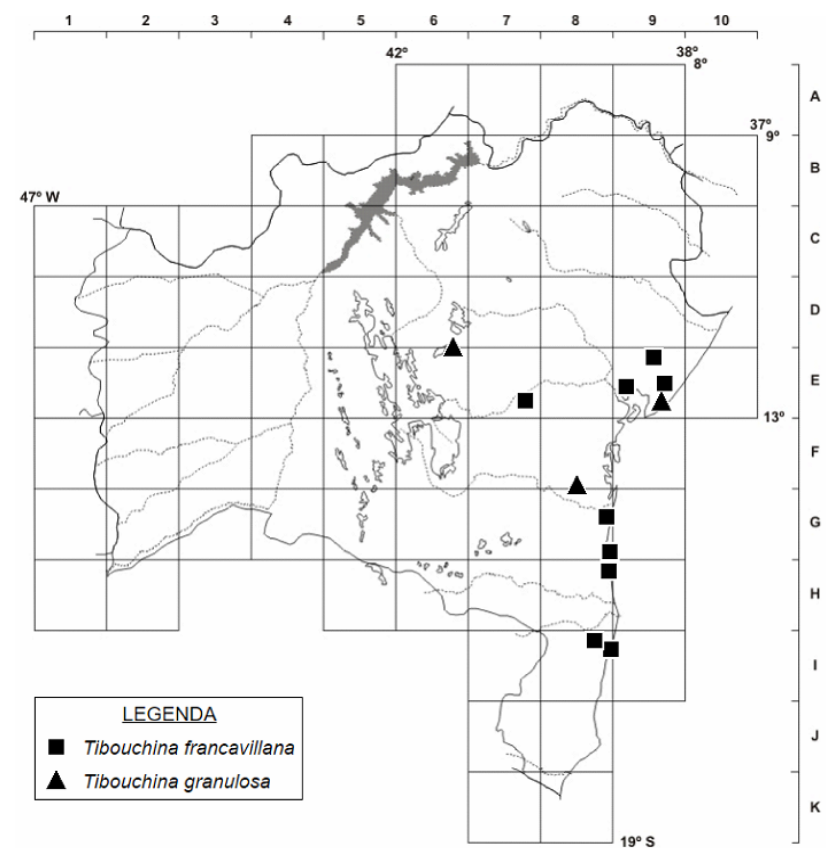

Figura 17. Mapa de distribuição geográfica de Tibouchina francavillana e T. granulosa no estado da Bahia.

Tibouchina granulosa é reconhecida pelos ramos alados e folhas com face abaxial estrigosa, contendo tricomas dendríticos, face adaxial escabra, com tricomas adpressos em forma de Y, de base espessada, e estilete com tricomas simples. Na Bahia, é constantemente utilizada em arborização de praças e jardins, devido à exuberante coloração das flores. É morfologicamente semelhante a $T$. fissinervia pelo hábito, estrutura dos ramos distais consistência das folhas e coloração das flores. São distintas pelos ramos subalados, folhas com tricomas simples, não adpressos na face adaxial e estilete com glândulas estipitadas em T. fissinervia.

17. Tibouchina heteromalla (D.Don) Cogn. in Martius \& Eichler, Fl. Bras. 14(3): 336. 1885.

Figuras 1O, 18A-D e 19.

Arbusto até $2 \mathrm{~m}$ alt.; ramos distais subcilíndricos a quadrangulares, não alados, seríceos, tricomas simples, ramos proximais cilíndricos; nós não circundados por coroa de tricomas. Folhas opostas; pecíolo 1-2,5 cm compr.; lâmina 5-13,5 × 3-7,5 cm, oval, coriácea, ápice agudo a obtuso, base arredondada, margem inteira, não ciliada, plana, discolor, face adaxial serícea, tricomas simples, face abaxial tomentosa, tricomas simples, 5 nervuras basais, raro suprabasais no último par. Inflorescências terminais, raque $8-25$ cm compr., tricomas simples; bractéolas ca. $0,6 \times 0,2-$ $0,4 \mathrm{~cm}$, elípticas, não involucrais, tricomas simples. Flores 5-meras; pedicelo 0,1-0,4 cm compr.; hipanto 0,4-0,5 × 0,2-0,4 cm, oblongo, seríceo, tricomas simples; sépalas 0,5-0,8 ×0,2-0,4 $\mathrm{cm}$, decíduas, ápice acuminado, não aristado; pétalas 1,3-2 × 1,2-1,5 cm, obdeltoides, ápice retuso ou irregular, lilás com base branca, passando a vermelhas após antese. Estames
10, dimorfos; filetes antissépalos $0,7-1 \mathrm{~cm}$ compr., os antipétalos 0,4-0,7 cm compr., glândulas estipitadas apenas no ciclo antissépalo; conectivos prolongados abaixo das anteras, os antissépalos ca. 0,3 cm compr., os antipétalos ca. 0,2 cm compr.; apêndices com glândulas estipitadas em ambos os ciclos; anteras antissépalas ca. 0,8 cm compr., as antipétalas ca. 0,6, brancas ou lilás. Ovário hirsuto no ápice; estilete reto, tricomas simples ou glândulas estipitadas na metade basal; estigma punctiforme. Cápsulas $0,4-0,8 \times 0,3-$ $0,5 \mathrm{~cm}$, não costadas.

Endêmica do Brasil, ocorre em Alagoas, Bahia, Ceará, Espírito Santo, Goiás, Minas Gerais, Paraíba, Pernambuco, Rio de Janeiro e Rio Grande do Norte (BFG 2015). F5, E9, F8, G8, H7, H8: restinga, borda de floresta ou no cerrado, em campo rupestre, no litoral sul, recôncavo sul, bacia do Paraguaçu, Serra Gerais e sudoeste da Bahia. Coletada em estágio reprodutivo em quase todos os meses do ano.

Material selecionado - Camacan, $15^{\circ} 23^{\prime} 30^{\prime \prime} \mathrm{S}, 3^{\circ} 33^{\prime} 55^{\prime \prime} \mathrm{W}, 9$ abr. 2006 (bot., fl.), R. Goldenberg et al. 847 (CEPEC); Caetité, 13'53'10"S, 42²7'15"W, 12 abr. 2005 (fr.), E.B. Miranda 780 (HUEFS); Entre Rios, $12^{\circ} 06^{\prime}$ S, 37 $37^{\circ} 9^{\prime} \mathrm{W}, 22$ jun. 2009 (bot., fl.), A.V. Popovkin 609 (HUEFS); Gandu, 1356.39'S, 39²9.23'W, 2 ago. 2009 J.G. Freitas 553 (HUEFS); Itagibá, 14 ${ }^{\circ} 10^{\prime} 02^{\prime \prime S}, 39^{\circ} 43^{\prime 2} 20^{\prime \prime} \mathrm{W}, 29$ maio 2008 (fl., fr.), C.E. Ramos 226 (ALCB); Macarani, 1546'19"S, 40²4'50"W, 17 ago. 2001 (bot.), A.M. Carvalho et al. 7020 (CEPEC); Salvador, 130' $46^{\prime \prime S}$, 38 $37^{\circ} 23^{\prime \prime W}, 15$ nov. 1997 (fr.), G.A. Faria et al. 194 (HRB); Ubaitaba, 1408'17"S, 39²1'24W, 2 ago. 2009 (fl., fr.), J.G. Freitas 550 (HUEFS).

Tibouchina heteromalla apresenta flores com pétalas lilás de base branca, tornando-se vermelhas após a antese, e estames dimorfos, com glândulas estipitadas nos apêndices. Na Bahia, é muito utilizada como ornamental, em praças e jardins. É morfologicamente semelhante a $T$. carvalhoi pelo hábito, forma e consistência das folhas, diferenciandose pelas glândulas estipitadas na inflorescência e nas folhas, flores lilás sem base branca e apêndices estaminais glabros em $T$. carvalhoi. Assemelha-se também a $T$. bahiensis (veja comentário naquela espécie).

18. Tibouchina lhotzkyana (C.Presl.) Cogn. in Martius \& Eichler, Fl. Bras. 14(3): 357. 1885.

Figuras 1P, 18E-I e 19.

Subarbusto ou arbusto 1-2 m alt.; ramos distais cilíndricos ou subcilíndricos, não alados, densoseríceo, tricomas simples, ramos proximais cilíndricos; nós não circundados por coroa de tricomas. Folhas opostas; pecíolo 1,2-1,7 cm compr.; lâmina 5-9 × 2,5$4,5 \mathrm{~cm}$, elíptica, coriácea, ápice acuminado, base obtusa a subcordada, margem inteira, não ciliada, plana, discolor, serícea em ambas as faces, tricomas simples, 5 nervuras basais. Inflorescências terminais, raque 4-14 cm compr., tricomas simples; bractéolas 0,7-0,9 × 0,2-0,3 cm, elíptico-lanceoladas, não involucrais, tricomas simples. Flores 5-meras; pedicelo ca. $0,4 \mathrm{~cm}$ compr.; hipanto $0,5-0,9 \times$ ca. $0,4 \mathrm{~cm}$, 


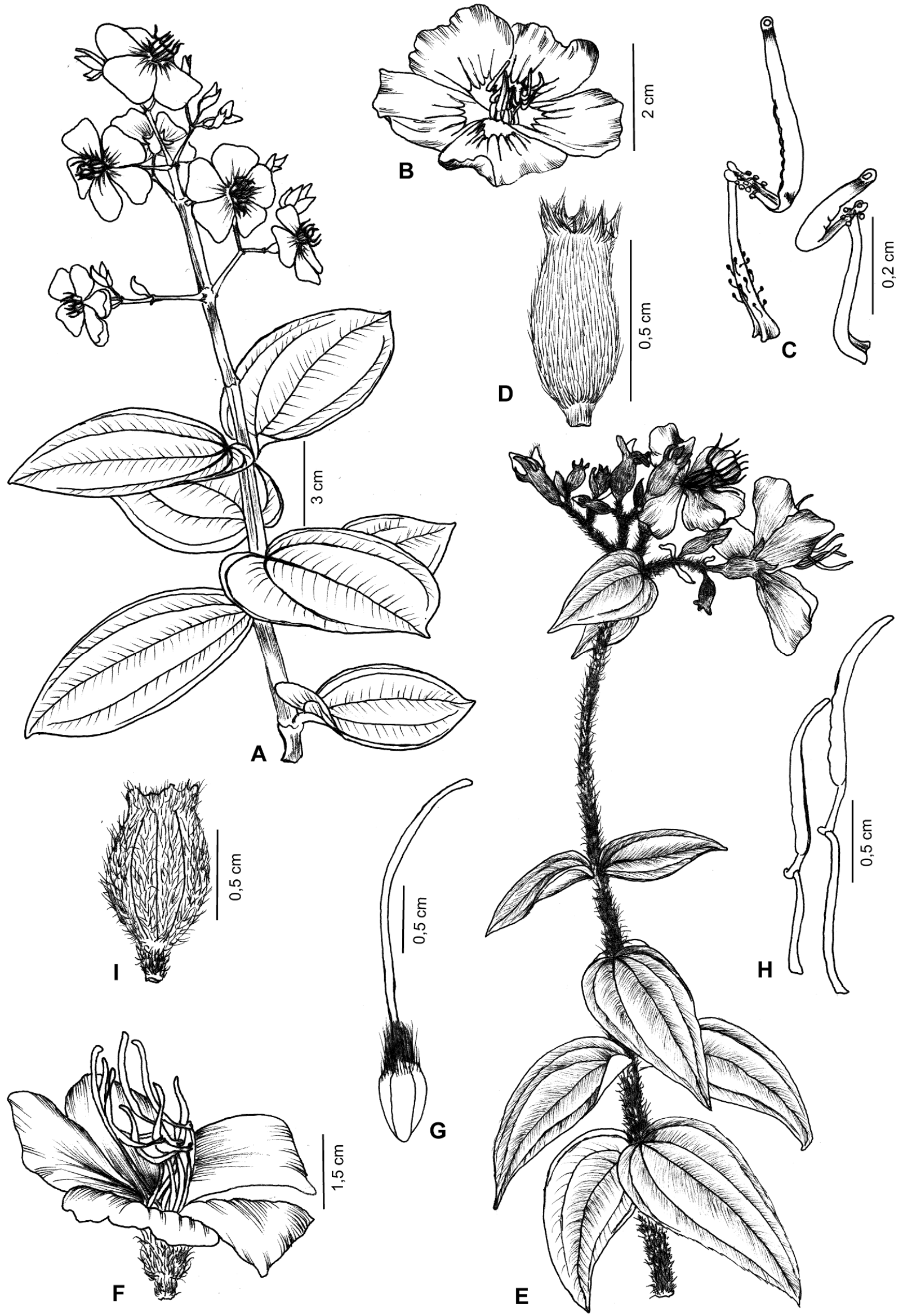

Figura 18. A-D. Tibouchina herteromalla: A- ramo com botões e flores; B- flor; C- estames de ambos os ciclos; D- fruto (Freitas 553 HUEFS). E-I. T. lhotzkyana: E- ramo com botões e flores; F- flor; G- gineceu; H- estames de ambos os ciclos; I- fruto (Freitas 554 HUEFS). 


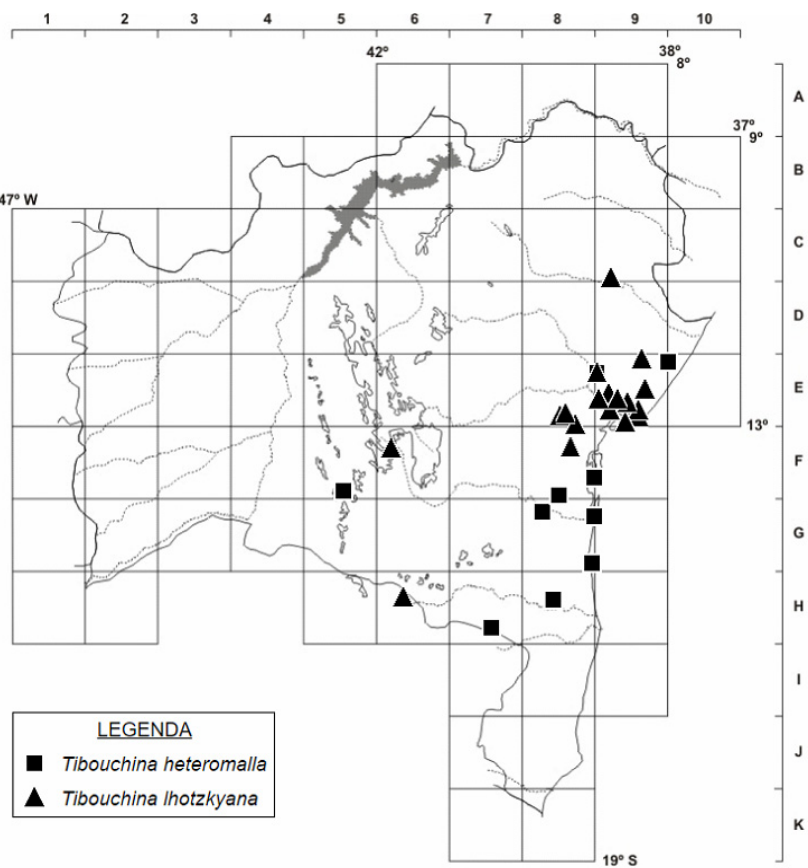

Figura 19. Mapa de distribuição geográfica de Tibouchina heteromalla e T. lhotzkyana no estado da Bahia.

oblongo, seríceo ou estrigoso, tricomas simples; sépalas ca. $0,4 \times 0,3 \mathrm{~cm}$, decíduas, ápice agudo, não aristado; pétalas 1,5-2 × 1,3-1,5 cm, obdeltoides, ápice truncado, lilás a púrpura. Estames 10, subisomorfos; filetes antissépalos 0,9-1,3 cm compr., os antipétalos ca. 0,9 cm compr., glabros ou com glândulas estipitadas em ambos os ciclos; conectivos prolongados abaixo das anteras, os antissépalos até 0,4 cm compr., os antipétalos ca. 0,2 cm compr., apêndices glabros em ambos os ciclos; anteras antissépalas 1-1,3 cm compr., as antipétalas $0,8-1 \mathrm{~cm}$ compr., róseas ou lilás. Ovário hirsuto no ápice; estilete curvo no ápice, glabro; estigma punctiforme. Cápsulas ca. $1 \times 0,5 \mathrm{~cm}$, não costadas.

Endêmica do Brasil, ocorre na Bahia, Espírito Santo, Paraíba, Pernambuco e Sergipe (BFG 2015). C9, E8, E9, F6, F8, H6: restinga, bordas de florestas e áreas antropizadas, como margem de rodovias, no litoral norte, litoral sul, recôncavo sul, região metropolitana de Salvador, bacia do Paraguaçu e nordeste do estado. Coletada em estágio reprodutivo em vários meses do ano.

Material selecionado - Abaíra, $13^{\circ} 18^{\prime} \mathrm{S}, 41^{\circ} 48^{\prime \prime} \mathrm{W}, 13$ mar. 1992 (bot., fl.), B. Stannard 51933 (HUEFS); Alagoinhas, $12^{\circ} 03^{\prime} 54^{\prime \prime S}, 38^{\circ} 21^{\prime} 34^{\prime \prime W}, 26$ set. 2009 (bot., fl.), J.G. Freitas 554 (HUEFS); Candeias, 12 $37^{\circ} \mathrm{S}, 38^{\circ} 57^{\prime} \mathrm{W}, 11$ nov. 1983 (bot.), H.P. Bautista et al. 120-7 (ALCB, HRB); Muritiba, 12³7'S, 38 $57^{\prime} \mathrm{W}$, 10 fev. 2001 (bot.), D.R. Vieira 04 (ALCB); Camaçari, 12²9'35"S, $38^{\circ} 18^{\prime} 47^{\prime \prime} \mathrm{W}, 18$ out. 1982 (bot., fl.), L.R. Noblick 2109 (HUEFS); Castro Alves, 1249'S, 39 $24^{\prime} \mathrm{W}, 20$ out. 1985 (fr.), C.A. Miranda 493 (HRB); Feira de Santana, $12^{\circ} 15^{\prime} \mathrm{S}, 38^{\circ} 58^{\prime} \mathrm{W}, 13$ ago. 2001 (fr.), M.V. Moraes 450 (HUEFS); Salvador, $12^{\circ} 29^{\prime} \mathrm{S}, 38^{\circ} 18^{\prime} \mathrm{W}, 18$ out. 1982 (fl., fr.), L.R. Noblick et al. 2109 (HRB); Santa Terezinha, $12^{\circ} 51^{\prime} 11^{\prime \prime} \mathrm{S}, 39^{\circ} 28^{\prime} 21^{\prime \prime} \mathrm{W}, 14$ nov. 1986 (fl., fr.), L.P.
Queiroz 1051 (HUEFS); Santo Amaro, 12³2'45"S, 38 48'09"W, 22 nov. 1986 (fr.), L.P. Queiroz 1363 (HUEFS, HRB); Saubara, $12^{\circ} 46^{\prime} 48^{\prime \prime} \mathrm{S}, 38^{\circ} 47^{\prime} 24^{\prime \prime W}, 2$ set. 2006 (bot.), A.M. Amorim et al. 6174 (CEPEC); Simões Filho, 12²47'S, 38 24'W, 7 set. 1975 (bot., fl.), F. Gama s.n. (ALCB 03165); Valença, 13\%16'49"S, 39²19'50"W, 4 set. 2006 (Bot., fl.), A.M. Amorim et al. 6272 (CEPEC).

Tibouchina lhotzkyana é reconhecida principalmente pelos ramos distais denso-seríceos, com tricomas simples. É morfologicamente semelhante a $T$. velutina, devido ao hábito e consistência das folhas, mas difere pelos ramos distais estrigosos, com tricomas espaçados, folhas com margem avermelhada e estilete com tricomas simples em $T$. velutina.

19. Tibouchina lithophila Wurdack, Brittonia 33(3): 305. 1981 .

Figuras 1Q, 20A-E e 21.

Subarbusto $0,5-1,5 \mathrm{~m}$ alt.; ramos distais subcilíndricos, não alados, estrigosos, tricomas simples, ramos proximais cilíndricos; nós não circundados por coroa de tricomas. Folhas opostas; pecíolo 0,5-1 cm compr.; lâmina 1,5-3,5 × 0,9-1,6 cm, oval, coriácea, ápice agudo, base obtusa, margem inteira, não ciliada, plana, discolor, face adaxial escabra, tricomas simples com base buladas, face abaxial estrigosa, tricomas simples, 5 nervuras basais. Inflorescências terminais, raque $3-10 \mathrm{~cm}$ compr., tricomas simples; bractéolas ca. $0,3 \times 0,2 \mathrm{~cm}$, elípticas, não involucrais, tricomas simples. Flores 5-meras; pedicelo ca. 0,2 cm compr.; hipanto $0,3-0,5 \times$ ca. 0,4 $\mathrm{cm}$, campanulado, estrigoso, tricomas simples com base bulada; sépalas ca. 0,5 ×0,2 cm, decíduas, ápice agudo, não aristado; pétalas 1,5-2,5 × 1-1,7 cm, obdeltoides, ápice reto, púrpura. Estames 10, dimorfos; filetes antissépalos ca. 0,9 cm compr., os antipétalos ca. 0,7 cm compr.; conectivos prolongados abaixo das anteras apenas no ciclo antissépalo, ca. 0,2 cm compr., apêndices com glândulas estipitadas em ambos os ciclos; anteras antissépalas ca. $0,5 \mathrm{~cm}$ compr., as antipétalas ca. 0,4 cm compr., lilás. Ovário hirsuto no ápice; estilete curvo no ápice, tricomas simples; estigma punctiforme. Cápsulas ca. 0,6 × 0,5 $\mathrm{cm}$, não costadas.

Endêmica da Bahia (BFG 2015), no centro-norte do estado, na Chapada Diamantina e bacia do Paraguaçu F6, E7, E8: inselbergs e campos rupestres. Coletada em estágio reprodutivo de dezembro a julho e outubro.

Material selecionado - Abaíra, $13^{\circ} 18^{\prime} \mathrm{S}, 41^{\circ} 48^{\prime \prime} \mathrm{W}, 13$ mar. 1992 (bot., fl.), B. Stannard 51933 (HUEFS); Iaçu, 12²42'S, $39^{\circ} 56^{\prime} \mathrm{W}, 26$ fev. 1983 (fr.), G.C.P. Pinto 168 (HRB); ib., 12² $42^{\prime} \mathrm{S}$, $39^{\circ} 56^{\prime} \mathrm{W}, 1993$ (fr.), G.C.P. Pinto 41/93 (HRB); Itaberaba, $12^{\circ} 30^{\prime} 04^{\prime \prime S}, 40^{\circ} 04^{\prime} 60^{\prime \prime W}, 5$ jun. 2005 (bot., fl), E. Melo et al. 3915 (CEPEC, HUEFS); Itatim, 12²4'40"S, 39²46'47"W, 3 jul. 2005 (fl., fr.), A.O. Moraes 45 (HUEFS); Milagres, $12^{\circ} 52^{\prime} 17^{\prime \prime S}, 39^{\circ} 51^{\prime} 09^{\prime \prime} \mathrm{W}$, 13 mar. 2005 (bot., fl.), F. França 5165 (HUEFS); Santa Terezinha, $12^{\circ} 48^{\prime} \mathrm{S}, 39^{\circ} 32^{\prime} \mathrm{W}, 29$ out. 1995 (fl.), E. Melo et al. 1355 (ALCB, HUEFS). 
Tibouchina lithophila é reconhecida pelo hábito subarbustivo, folhas com face adaxial escabra e tricomas bulados na base, hipanto campanulado com sépalas não aristadas e estames claramente dimorfos, com glândulas nos apêndices estaminais de apenas um dos ciclos. Assemelha-se a T. noblickii pelo tipo de hábito, coloração e disposição das folhas, congestas apenas nos ramos distais. Distinguem-se pelo indumento da face adaxial das folhas com tricomas simples, sem base bulada, hipanto urceolado, sépalas com arista e estames subisomorfos em $T$. noblickii.

20. Tibouchina luetzelburgii Markgr., Notizbl. Bot. Gart. Berlin-Dahlem 10: 49. 1927.

Figuras 20F-I e 21.

Arbusto 1,5-2 m alt.; ramos distais quadrangulares, não alados, estrigosos, tricomas simples, ramos proximais cilíndricos; nós não circundados por coroa de tricomas. Folhas opostas; pecíolo 0,5-1,3 cm compr.; lâmina 4-8,5 × 0,6-2,4 cm, elípticolanceolada, coriácea, ápice apiculado, base cuneada a obtusa, margem inteira, não ciliada, plana, discolor, face adaxial glabra ou raramente com glândulas sésseis, face abaxial estrigosa, tricomas simples, 5 nervuras basais. Inflorescências terminais, raque 5-16 cm compr., tricomas simples; bractéolas $0,4-0,6 \times 0,1-$ $0,2 \mathrm{~cm}$, elíptico-lanceoladas, não involucrais, tricomas simples. Flores 5(6)-meras; pedicelo $0,3-0,5 \mathrm{~cm}$ compr.; hipanto $0,7-0,9 \times$ ca. $0,4 \mathrm{~cm}$, urceolado, estrigoso, glândulas estipitadas; sépalas $0,5-0,7 \times$ ca. $0,3 \mathrm{~cm}$, decíduas, ápice agudo, não aristado; pétalas 1,4-1,6 × 0,9-1,1 cm, obdeltoides, ápice truncado, lilás. Estames 10, isomorfos; filetes $0,8-1,2 \mathrm{~cm}$ compr., glabros ou com glândulas estipitadas; conectivos prolongados abaixo das anteras, ca. $0,2 \mathrm{~cm}$ compr., apêndices com glândulas estipitadas; anteras $0,8-0,9 \mathrm{~cm}$ compr., lilás. Ovário hirsuto no terço apical; estilete reto, glabro; estigma punctiforme. Cápsulas $0,5-0,8 \times 0,5 \mathrm{~cm}$, não costadas.

Endêmica da Bahia (BFG 2015), na Chapada Diamantina. F5, F6: campos rupestres. Coletada florida em agosto e setembro.

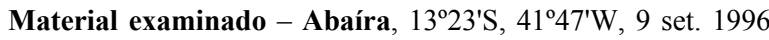
(fl., fr.), R.M. Harley 28397 (HUEFS); Rio de Contas, 13²4'S, 42²6'W, 8 ago. 1993 (bot., fl.), W. Ganev 2045 (HUEFS).

Tibouchina luetzelburgii apresenta folhas elípticolanceoladas, com 5 nervuras principais, face adaxial glabra ou raramente com glândulas sésseis, sépalas longas, sem arista, e estames isomorfos. É morfologicamente semelhante a $T$. salviifolia, pelo tipo de hábito e forma elíptico-lanceolada das folhas, mas diferem pelas folhas sem glândulas, com 3 nervuras principais e face adaxial escabra, de tricomas simples, sépalas com arista e estames subisomorfos em $T$. salviifolia.

21. Tibouchina macrochiton Cogn. in Martius \& Eichler, Fl. Bras. 14(3): 313. 1885.

Figuras 1R, 22A-E e 23.
Arvoreta 3-4 m alt.; ramos distais e proximais cilíndricos, não alados, glabros ou com tricomas simples espaçados; nós não circundados por coroa de tricomas. Folhas opostas; pecíolo 1-1,5 cm compr.; lâmina 3-5 × 1,5-2,5 cm, oblonga a oval, coriácea, ápice mucronulado a obtuso, base obtusa, margem inteira, não ciliada, plana, concolor, escabra em ambas as faces, tricomas simples, circundados por glândulas sésseis na face abaxial, 3 nervuras basais. Inflorescências terminais, raque $3-14 \mathrm{~cm}$ compr., glabros ou tricomas simples; bractéolas ca. 1,9 $\times 0,7$ $\mathrm{cm}$, elípticas, não involucrais, tricomas simples. Flores 5-meras; pedicelo 0,3-0,5 cm compr.; hipanto 0,5-0,8 $\times$ ca. $0,4 \mathrm{~cm}$, urceolado, estrigoso, tricomas simples; sépalas $0,3-0,5 \times 0,2-0,3 \mathrm{~cm}$, decíduas, ápice apiculado, não aristado; pétalas $2-2,5 \times 1,3-1,5 \mathrm{~cm}$, obdeltoides, ápice truncado, lilás ou púrpura. Estames 10 , isomorfos; filetes $1,2-1,5 \mathrm{~cm}$ compr., glabros ou raramente com tricomas simples longos; conectivos prolongados abaixo das anteras, $0,1-0,2 \mathrm{~cm}$ compr., apêndices glabros; anteras 1,5-2 cm compr., lilás ou brancas. Ovário hirsuto no ápice; estilete reto, glabro ou com tricomas simples e espaçados; estigma punctiforme. Cápsulas $0,8-1 \times 0,6-0,8 \mathrm{~cm}$, não costadas.

Endêmica do Brasil, ocorre na Bahia e Espírito Santo (BFG 2015). E6, I8, J8: extremo sul e Chapada Diamantina, em floresta ombrófila e/ou mata ciliar. Coletada com flores em quase todos os meses do ano (outubro a agosto).

Material selecionado - Alcobaça, $17^{\circ} 32^{\prime} \mathrm{S}, 39^{\circ} 15^{\prime} \mathrm{W}, 21$ out. 1993 (fl., fr.), W.W. Thomas et al. 10042 (HRB); Caravelas, $17^{\circ} 37^{\prime} 15^{\prime \prime S}, 39^{\circ} 13^{\prime} 29^{\prime \prime} \mathrm{W}, 6$ out. 2000 (est.), L.A. Matos-Silva et al.

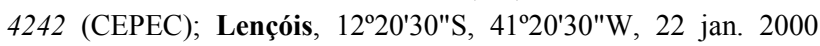
(bot., fl.), A.A. Ribeiro-Filho et al. 7 (ALCB, HUEFS); Porto Seguro, 165' ${ }^{\circ}$ S 3909'W, 14 dez. 1991 (bot.), M.C. Ferreira 468

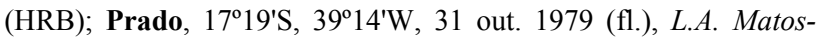
Silva 709 (CEPEC).

Tibouchina macrochiton é reconhecida pelas folhas 3-nervadas, com face abaxial escabra e tricomas circundados por glândulas sésseis, ramos distais e pecíolos vermelhos, além das grandes bractéolas avermelhadas. Dentre as espécies que ocorrem na Bahia, é mais semelhante a $T$. barnebyana (veja comentários naquela espécie).

22. Tibouchina noblickii Wurdack, Kew Bull. 50(4): 823; fig. 1T, 22E-K, 23. 1995.

Figuras $1 \mathrm{~T}, 22 \mathrm{~F}-\mathrm{K}$ e 23.

Arbusto 0,5-2 $\mathrm{m}$ alt.; ramos distais quadrangulares, não alados, estrigosos, tricomas simples e glândulas estipitadas, ramos proximais cilíndricos; nós não circundados por coroa de tricomas. Folhas opostas; pecíolo 0,5-1 cm compr.; lâmina 1,5-2,8 × 0,8-1,8 cm, elíptica, coriácea, ápice mucronulado, base obtusa, margem inteira, não ciliada, plana, discolor, estrigosa em ambas as faces, tricomas simples, 5 nervuras basais. Inflorescências terminais, raque $3-8 \mathrm{~cm}$ compr., tricomas simples; bractéolas $0,4-0,6 \times$ ca. 0,3 


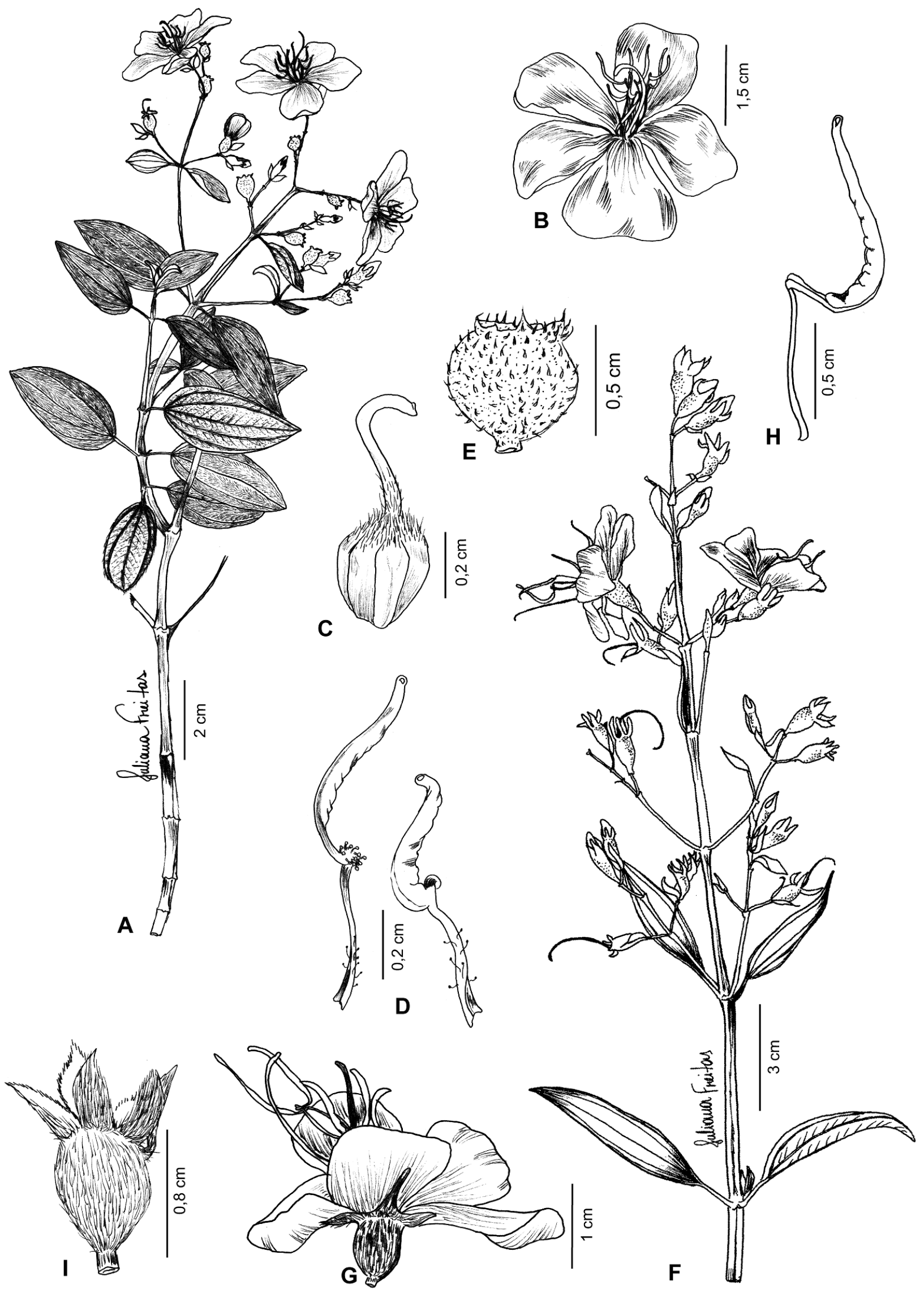

Figura 20. A-E. Tibouchina lithophila: A- ramo com flores e frutos; B- flor; C- gineceu; D- estames de ambos os ciclos; E- fruto (França 1370 HUEFS). F-I. T. luetzelburgii: F- ramo com botões e flores; G- flor; H- estame; I- fruto, evidenciando sépalas persistentes (Ganev 2045 HUEFS). 
cm, elípticas, côncavas, não involucrais, tricomas simples. Flores 5-meras; pedicelo 0,2-0,4 cm compr.; hipanto $0,5-0,7 \times$ ca. $0,4 \mathrm{~cm}$, urceolado, estrigoso, tricomas simples e glândulas estipitadas; sépalas 0,3$0,5 \times$ ca. $0,2 \mathrm{~cm}$, decíduas, ápice obtuso, aristado; pétalas 1-2 × 0,5-1,5 cm, obdeltoides, ápice truncado, lilás. Estames 10, subisomorfos; filetes antissépalos ca. 1,1 cm compr., os antipétalos ca. 0,9 cm compr., glândulas estipitadas em ambos os ciclos; conectivos prolongados abaixo das anteras, os antissépalos ca. 0,4 cm compr., os antipétalos ca. 0,2 cm compr., apêndices glabros em ambos os ciclos; anteras antissépalas ca. 1 cm compr., as antipétalas ca. 0,8 cm compr., lilás. Ovário hirsuto no terço apical; estilete reto com glândulas estipitadas; estigma truncado. Cápsulas 0,6$0,9 \times$ ca. $0,5 \mathrm{~cm}$, não costadas.

Endêmica da Bahia (BFG 2015), na bacia do Paraguaçu. E8: inselbergs associados à caatinga. Coletada em estágio reprodutivo de novembro a março e junho.

Material selecionado - Anguera, 12 $02^{\circ} 59^{\prime \prime} \mathrm{S}, 39^{\circ} 11^{\prime} 03^{\prime \prime} \mathrm{W}, 28$ nov. 2006 (bot., fl.), D. Cardoso 1466 (HUEFS); Feira de Santana, $12^{\circ} 16^{\prime} 19^{\prime \prime} \mathrm{S}, 39^{\circ} 03^{\prime} 39^{\prime \prime} \mathrm{W}, 11$ mar. 2003 (bot.), A.K.A. Santos 45 (HUEFS).

Tibouchina noblickii é reconhecida pela disposição das folhas nos ramos, estrutura da inflorescência, hipanto e sépalas com glândulas estipitadas e folhas com menos de $3 \mathrm{~cm}$ de comprimento. A espécie morfologicamente mais parecida na Bahia é $T$. lithophila (veja comentários naquela espécie).

23. Tibouchina oreophila Wurdack, Brittonia 33(3): 305. 1981.

Figuras 1U, 24A-E e 25.

Subarbusto ou arbusto 0,5-1,5 m alt; ramos distais subcilíndricos, não alados, escabros, tricomas dendríticos, ramos proximais cilíndricos; nós não circundados por coroa de tricomas. Folhas opostas; pecíolo 0,2-0,5 cm compr.; lâmina $1-4 \times 0,8-2,6 \mathrm{~cm}$, elíptica a cordada, coriácea, ápice agudo a mucronulado, base obtusa a cordada, margem inteira, não ciliada, plana, discolor, face adaxial escabra, tricomas dendríticos no ápice e bulados na base, face abaxial estrigosa, tricomas dendríticos, 5 nervuras basais. Inflorescências terminais, raque 3-12 cm compr., tricomas dendríticos; bractéolas não vistas. Flores 5-meras; pedicelo 0,1-0,2 cm compr.; hipanto 0,5-0,7 $\times$ 0,4-0,6 cm, campanulado, estrigoso, tricomas dendríticos; sépalas $0,6-0,8 \times 0,1-0,3 \mathrm{~cm}$, decíduas, ápice agudo a apiculado, não aristado; pétalas 1,7-2,3 × 1,1-1,5 cm, obdeltoides, ápice truncado, lilás. Estames 10, subisomorfos; filetes antissépalos ca. 1,2 cm compr., os antipétalos ca. $1 \mathrm{~cm}$ compr., glabros, raro glândulas estipitadas, em ambos os ciclos; conectivos prolongados abaixo das anteras, os antissépalos ca. 0,3 cm compr., os antipétalos ca. 0,2 cm compr., apêndices glabros em ambos os ciclos; anteras antissépalas ca. 0,8 cm compr., as antipétalas ca. 0,6 cm compr., lilás. Ovário hirsuto no terço

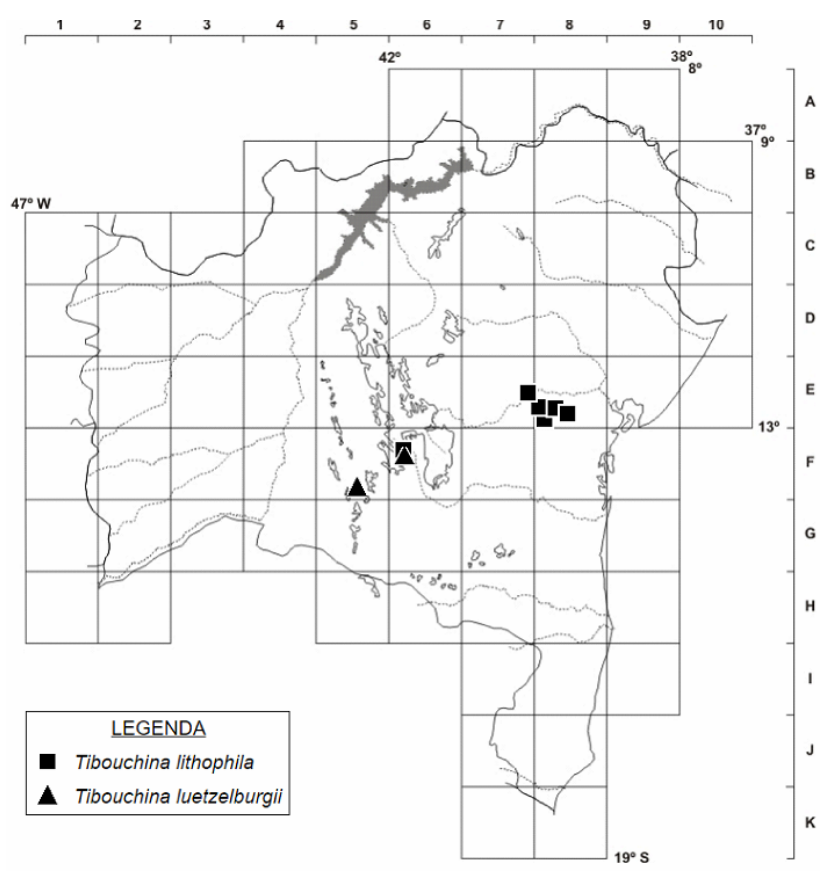

Figura 21. Mapa de distribuição geográfica de Tibouchina lithophila e T. luetzelburgii no estado da Bahia.

apical; estilete reto, glabro; estigma truncado. Cápsulas $0,8-1 \times 0,5-0,8 \mathrm{~cm}$, não costadas.

Endêmica da Bahia (BFG 2015), na Chapada Diamantina e bacia do Paraguaçu. E6, E7, F6: campo rupestre ou cerrado. Coletada em estágio reprodutivo em quase todos os meses do ano (outubro a julho).

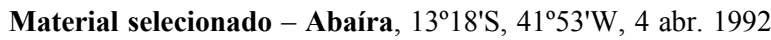
(fl., fr.), W. Ganev 36 (HUEFS); Barra da Estiva, $13^{\circ} 42^{\prime} \mathrm{S}$, $41^{\circ} 16^{\prime} \mathrm{W}, 24$ mar. 1980 (fl.), R.M. Harley et al. 20855 (CEPEC);

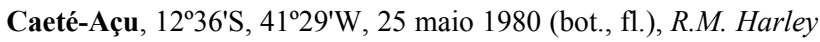

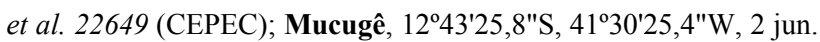
2009 (bot., fl.), J.G. Freitas et al. 542 (HUEFS); Palmeiras, 12 $37^{\prime} 20^{\prime \prime S}, 41^{\circ} 28^{\prime} 155^{\prime \prime W}, 26$ out. 1994 (fr.), A.M. Carvalho et al.

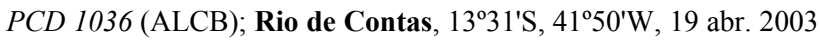
(fl., fr.), A.K.A. Santos 76 (HUEFS); Rui Barbosa, 12 $18^{\prime} 36^{\prime \prime S}$, 40²0'49"W, 14 mar. 1999 (fl.), F. França 2652 (HUEFS).

Tibouchina oreophila é reconhecida palas folhas congestas nos ramos distais, fortemente discolores, adaxialmente escabras, com tricomas dendríticos no ápice e bulados na base. Dentre as espécies que ocorrem na Bahia, $T$. oreophila assemelha-se morfologicamente a $T$. crassiramis (veja comentários naquela espécie).

24. Tibouchina pauloalvinii Vinha, Bradea 1(30): 320. 1973 (como 'paulo-alvinii').

Figuras 24F-J e 25.

Subarbusto ou arbusto 1-2 $\mathrm{m}$ alt.; ramos distais quadrangulares, não alados, estrigosos, glândulas estipitadas, ramos proximais cilíndricos; nós não circundados por coroa de tricomas. Folhas opostas; pecíolo 1-2,5 cm compr.; lâmina 7-12,5 × 3,5-6,5 cm, oval-elíptica, membranácea, ápice apiculado, base subcordada, margem inteira, não ciliada, plana, levemente discolor, serícea em ambas as faces, 

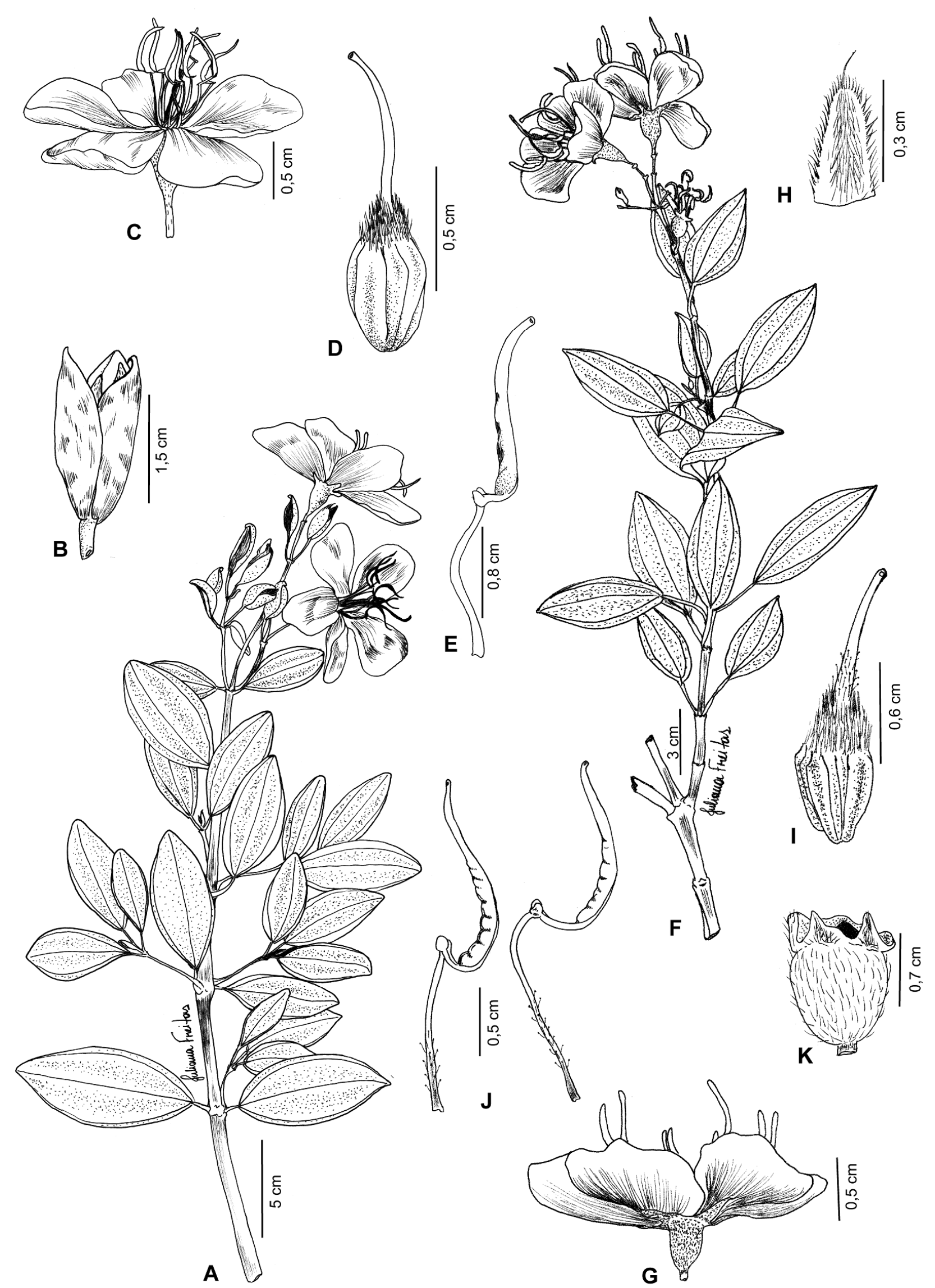

Figura 22. A-E. Tibouchina macrochiton: A- ramo com botões e flores; B- botão floral evidenciando bractéolas; C- flor; D- gineceu; E- estame (Martinelli 6010 CEPEC). F-K. T. noblickii: F- ramo com flores; G- flor; H- sépala com ápice aristado; I- gineceu; J- estames de ambos os ciclos; K- fruto (Cardoso 1466 HUEFS). 
tricomas simples, 5 nervuras suprabasais no último par. Inflorescências terminais, raque 5-7 cm compr., tricomas simples e glândulas estipitadas; bractéolas $0,5-0,7 \times 0,3-0,5 \mathrm{~cm}$, elípticas, não involucrais, glândulas estipitadas. Flores 5-meras; pedicelo 0,2-0,4 $\mathrm{cm}$ compr.; hipanto $0,9-1,3 \times$ ca. $0,4 \mathrm{~cm}$, oblongo, seríceo, glândulas estipitadas; sépalas $0,5-0,8 \times$ ca. 0,3 $\mathrm{cm}$, decíduas, ápice agudo, aristado; pétalas 2-2,3 $\times$ 1,1-1,3 cm, obdeltoide, ápice truncado, lilás. Estames 10, subisomorfos; filetes antissépalos ca. $1,2 \mathrm{~cm}$ compr., os antipétalos ca. $1 \mathrm{~cm}$ compr., glândulas estipitadas em ambos os ciclos; conectivos prolongados abaixo das anteras, os antissépalos ca. 0,3 cm compr., os antipétalos ca. $0,1 \mathrm{~cm}$ compr., apêndices glabros em ambos os ciclos; anteras antissépalas ca. $1,4 \mathrm{~cm}$ compr., as antipétalas ca. $1 \mathrm{~cm}$ compr., lilás. Ovário hirsuto no terço apical; estilete reto, glândulas estipitadas na metade basal; estigma punctiforme. Cápsulas $0,8-1 \times 0,3-0,6 \mathrm{~cm}$, costadas.

Endêmica da Bahia (BFG 2015), no litoral sul. G8: floresta ombrófila. Coletada em estágio reprodutivo de março a julho.

Material examinado - Ilhéus, quadra da reserva zoobotânica, 31 maio 1979 (fl., fr.), L.A. Matos-Silva et al. 405 (CEPEC); Taboquinha, 14 jul. 1971 (bot., fr.), T.S. Santos 1764 (CEPEC); Uruçuca, rodovia Uruçuca-Taboquinha, 22 jul. 1971 (bot., fl.), R.S. Pinheiro 1471 (CEPEC).

Tibouchina pauloalvinii é reconhecida pelas glândulas estipitadas nos ramos distais, hipanto e sépalas, folhas membranáceas e sépalas aristadas. É semelhante a $T$. stipulacea, pelo hábito e pelas folhas membranáceas, a qual se distingue por possuir uma coroa de tricomas em volta dos nós, cálice sem arista e ausência de glândulas nos ramos distais.

\section{Tibouchina pereirae Brade \& Markgr.,} Willdenowia 2(5): 772. 1961.

Figuras 1V, 26A-D e 27.

Arbusto ou subarbusto 1-2 $\mathrm{m}$ alt.; ramos distais quadrangulares, não alados, estrigosos, tricomas simples e glândulas estipitadas, ramos proximais cilíndricos; nós não circundados por coroa de tricomas. Folhas opostas; pecíolo $0,5-1,5 \mathrm{~cm}$ compr.; lâmina 2 $8 \times 1,5-4 \mathrm{~cm}$, elíptica a oval ou cordada, coriácea, ápice agudo a acuminado, base cuneada, obtusa, cordada ou subcordada, margem inteira, não ciliada, plana, discolores, estrigosas em ambas as faces, tricomas simples, 5 ou 7 nervuras basais ou suprabasais no último par. Inflorescências terminais, raque 4-15 cm compr., tricomas simples e/ou glândulas estipitadas; bractéolas $0,5-1,5 \times 0,3-0,8 \mathrm{~cm}$, lanceoladas, elípticas ou ovais, decíduas, tricomas simples e/ou glândulas estipitadas. Flores 5-meras; pedicelo $0,3-2 \mathrm{~cm}$ compr.; hipanto $0,5-1,3 \times 0,3-0,6$ $\mathrm{cm}$, urceolado ou oblongo, estrigoso, às vezes glândulas estipitadas; sépalas $0,4-0,7 \times 0,3 \mathrm{~cm}$, decíduas ou persistentes, ápice apiculado, não aristado; pétalas 1-2 × 0,8-1 cm, obdeltoides, ápice reto, púrpura, lilás, róseas ou esbranquiçadas. Estames 10,

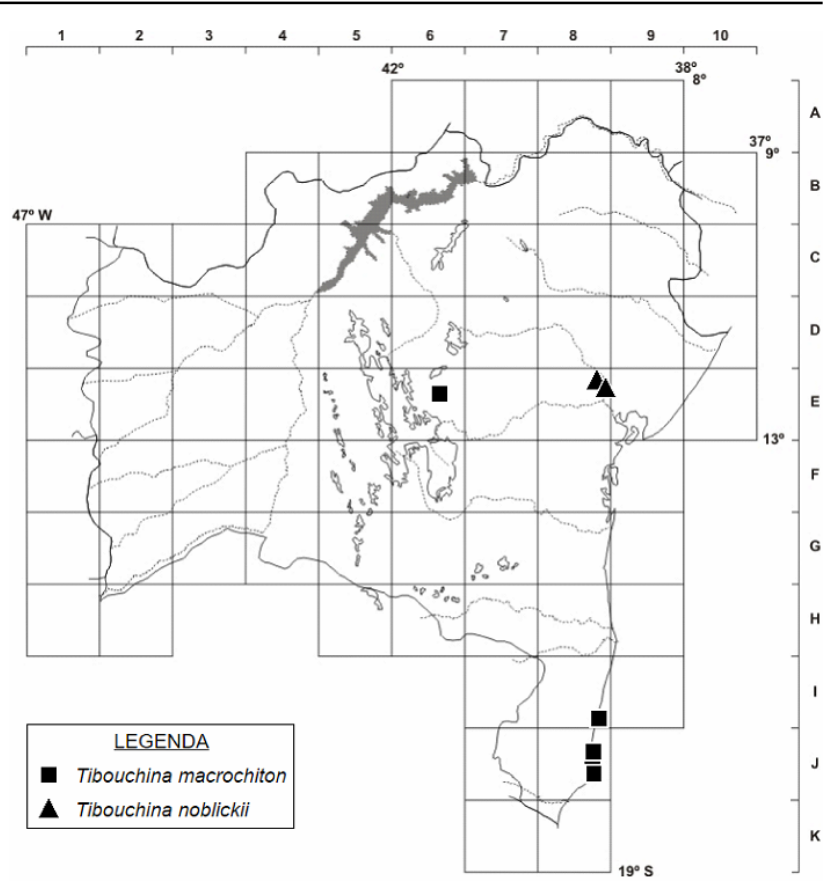

Figura 23. Mapa de distribuição geográfica de Tibouchina macrochiton e T. noblickii no estado da Bahia.

subisomorfos; filetes antissépalos 1-1,4 cm compr., os antipétalos $0,5-0,8 \mathrm{~cm}$ compr., glândulas estipitadas em ambos os ciclos; conectivos prolongados ou não abaixo das anteras, os antissépalos até $0,5 \mathrm{~cm}$ compr., os antipétalos $0,1-0,3 \mathrm{~cm}$ compr., apêndices glabros em ambos os ciclos; anteras antissépalas até $1,3 \mathrm{~cm}$ compr., as antipétalas até $0,7 \mathrm{~cm}$ compr., lilás, róseas ou esbranquiçadas. Ovário com tricomas hirsutos no ápice; estilete reto ou encurvado no ápice, glabro ou com glândulas estipitadas; estigma punctiforme. Cápsulas $0,8-1,5 \times 0,3-0,7 \mathrm{~cm}$, costadas ou não.

Endêmica da Bahia (BFG 2015), na Chapada Diamantina, piemonte da diamantina e Serra Geral. D6, D7, E6, F5, F6: cerrado e campo rupestre. Coletada em estágio reprodutivo em quase todos os meses do ano.

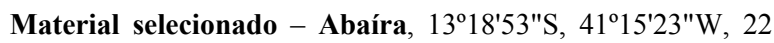
jul. 2003 (fl., fr.), A.S. Conceição 634 (HUEFS); Caetité, $14^{\circ} 21^{\prime} 32^{\prime \prime S}, 42^{\circ} 32^{\prime} 14^{\prime \prime W}$ ago. 2008 (fr.), M.S. Mendes 510 (HUEFS); Erico Cardoso, 13 ${ }^{\circ} 16^{\prime} 16^{\prime \prime} \mathrm{S}, 42^{\circ} 5^{\prime} 54^{\prime \prime} \mathrm{W}, 4$ jul. 2001 (fr.),

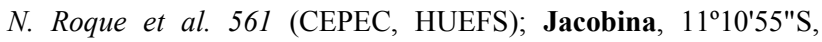
40'30'42"W, 24 nov. 2001 (fr.), D.M. Loureiro et al. 470 (ALCB);

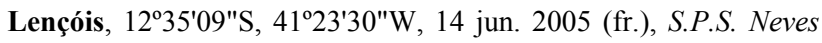

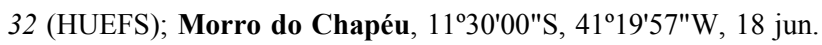
2004 (fr.), E.B. Souza 942 (HUEFS); Mucugê, 1259'53,4"S, 41 20 '54,4"W, 2 jun. 2009 (fl.), J.G. Freitas 538 (HUEFS);

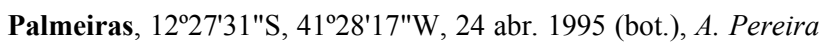
et al. PCD 1744 (ALCB, CEPEC, HRB); Piatã, $13^{\circ} 01^{\prime} \mathrm{S}, 41^{\circ} 32^{\prime} \mathrm{W}$, 19 set. 2004 (bot., fr.), M.L. Guedes 11334 (ALCB); Rio de Contas, 1327'33"S, 41 ${ }^{\circ} 52^{\prime} 24 " W, 4$ fev. 1997 (bot., fl.), L. Passos et al. PCD 5038 (ALCB, CEPEC).

Tibouchina pereirae é reconhecida pelo hábito arbustivo, muito ramificado, com ramos estrigosos, com ou sem glândulas estipitadas nos eixos das inflorescências, bractéolas com formas e tamanhos 


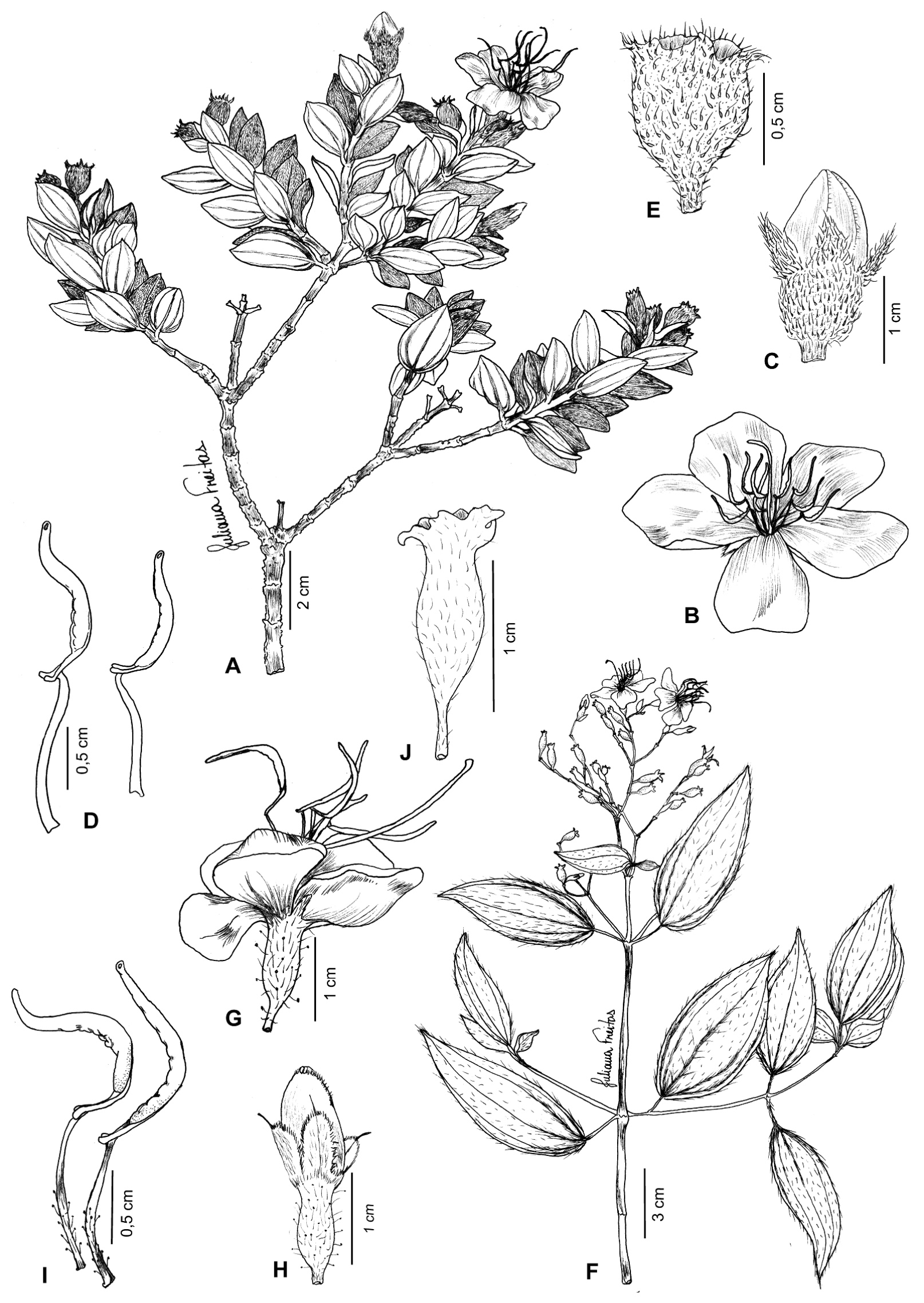

Figura 24. A-E. Tibouchina oreophila: A- ramo com botões, flores e frutos; B- flor; C- botão floral; D- estames de ambos os ciclos; E- fruto (Souza 1002 HUEFS). F-J. T. pauloalvinii: F- ramo com flores e frutos; G- flor; H- botão floral evidenciando sépalas com aristas; I- estames de ambos os ciclos; J- fruto (Santos 527 CEPEC). 


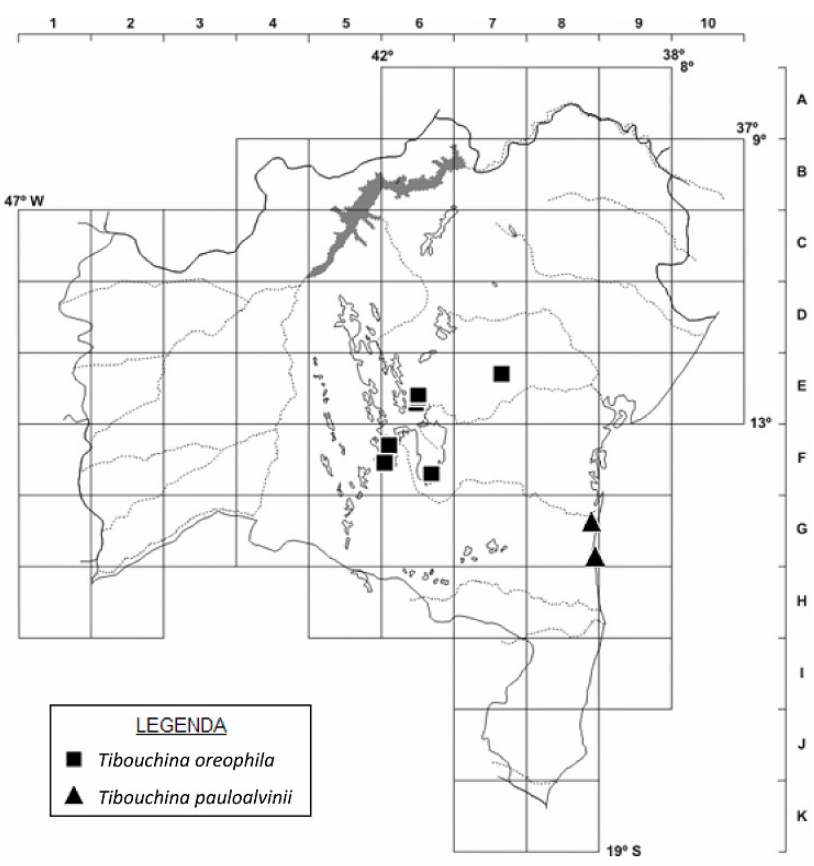

Figura 25. Mapa de distribuição geográfica de Tibouchina oreophila e $T$. pauloalvinii no estado da Bahia.

variados e hipanto urceolado a oblongo, com cores e indumentos variados. Entretanto, possui difícil delimitação devido à sobreposição de características morfológicas com $T$. carvalhoi, $T$. riparia e $T$. velutina. Assim, T. pereirae é tratada aqui como espécie polimórfica e parte de um complexo de espécies que ainda carece de estudos morfológicos e genéticos detalhados visando o reconhecimento de relações e identidades específicas. É mais dificilmente distinguida de $T$. riparia, que difere de $T$. pereirae apenas pelas folhas sésseis ou com pecíolo menor que $0,3 \mathrm{~cm}$ de comprimento.

\section{Tibouchina rigidula (Naudin) Wurdack,} Phytologia 21(2): 116. 1971.

Figuras 1W, 26E-H e 27.

Arvoreta 2-5 $\mathrm{m}$ alt.; ramos distais subcilíndricos, não alados, denso-estrigosos, tricomas simples, ramos proximais cilíndricos; nós não circundados por coroa de tricomas. Folhas opostas; pecíolo ca. $0,5 \mathrm{~cm}$ compr.; lâmina 2-5 ×0,9-2 cm, oval, coriácea, ápice agudo, base obtusa, margem inteira, ciliada, plana, discolor, face adaxial escabra, tricomas simples, face abaxial estrigosa, tricomas dendríticos, 5 nervuras basais. Inflorescências terminais, raque $6-10 \mathrm{~cm}$ compr., tricomas dendríticos; bractéolas 0,5-0,7 × 0,4$0,6 \mathrm{~cm}$, ovais, não involucrais, tricomas dendríticos. Flores 5-meras; pedicelo 0,1-0,3 cm compr.; hipanto $0,4-0,5 \times 0,3-0,4 \mathrm{~cm}$, urceolado, estrigoso, tricomas dendríticos; sépalas 0,4-0,5 × 0,2-0,3 cm, decíduas, ápice agudo, não aristado; pétalas 1,7-2 × 1-1,6 cm, obdeltoides, ápice arredondado, lilás. Estames 10, dimorfos; filetes antissépalos 0,8-1 cm compr., os antipétalos $0,5-0,6 \mathrm{~cm}$ compr., glândulas estipitadas em ambos os ciclos; conectivos prolongados abaixo das anteras apenas no ciclo antissépalo, ca. $0,1 \mathrm{~cm}$ compr., apêndices glabros em ambos os ciclos; anteras antissépalas até $0,9 \mathrm{~cm}$ compr., as antipétalas 0,5-0,6 $\mathrm{cm}$ compr., lilás ou róseas. Ovário hirsuto no terço apical; estilete curvo no ápice, glabro; estigma punctiforme. Cápsulas ca. $0,6 \times 0,4 \mathrm{~cm}$, não costadas.

Endêmica do Brasil, ocorre na Bahia e Minas Gerais (BFG 2015). H6. Coletada com flores e frutos em fevereiro e junho e fotografada com flores e frutos em janeiro.

Material examinado - s.l., rodovia BR-4, 24 jun. 1965 (bot., fr.), H.P. Belém 1154 (CEPEC, MBM, UB).

Material adicional examinado - BRASIL. MINAS GERAIS: Botumirim, estrada Botumirim-Itacambira, 16 $48^{\prime} 02^{\prime \prime} \mathrm{S}, 43^{\circ} 26^{\prime} 07^{\prime \prime} \mathrm{W}$, 15 fev. 2003, (fl., fr.) F. França et al. 4399 (HUEFS).

Tibouchina rigidula é reconhecida pelos ramos distais denso-estrigosos, com longos tricomas amarronzados, folhas ovais, com margens ciliadas, face abaxial estrigosa e tricomas dendríticos. É morfologicamente semelhante a T. stenocarpa, pelo hábito, intensidade de flores por inflorescência e consistência das folhas. No entanto, esta última possui folhas elípticas, com tricomas adpressos na face adaxial, ramos distais com tricomas dendríticos espaçados e estames denso-seríceos, com tricomas simples. Devido ao estado incompleto do material proveniente da Bahia, a descrição de $T$. rigidula foi complementada com informações de uma amostra coletada em Minas Gerais. O material herborizado não conta com informação precisa (coordenadas geográficas) do local de coleta, mas há registros fotográficos que confirmam a ocorrência da espécie na Bahia.

27. Tibouchina riparia Markgr., Notizbl. Bot. Gart. Berlin-Dahlem 10: 50. 1927.

Figuras 1X, 28A-E e 29.

Arbusto 1,5-2 m alt.; ramos distais quadrangulares, não alados, estrigosos, tricomas simples, ramos proximais cilíndricos; nós não circundados por coroa de tricomas. Folhas opostas, subsésseis; pecíolo até 0,3 cm compr.; lâmina $2-5 \times 1,5-2,5 \mathrm{~cm}$, oval-elíptica, coriácea, ápice agudo, base cordada, margem inteira, não ciliada, plana, discolor, estrigosa em ambas as faces, tricomas simples, 5 ou 7 nervuras suprabasais no último par. Inflorescências terminais, raque $8-12 \mathrm{~cm}$ compr., tricomas simples; bractéolas $0,3-0,5 \times 0,1-0,2$ $\mathrm{cm}$, elípticas, não involucrais, tricomas simples. Flores 5-meras; pedicelo até $0,3 \mathrm{~cm}$ compr.; hipanto $1-1,3 \times$ 0,3-0,5 cm, oblongo, estrigoso, tricomas simples; sépalas $0,4-0,6 \times 0,2-0,3 \mathrm{~cm}$, persistentes, ápice apiculado, não aristado; pétalas $1-1,2 \times 0,5-0,6 \mathrm{~cm}$, obovais, ápice arredondado, lilás. Estames 10, subisomorfos; filetes antissépalos ca. $1 \mathrm{~cm}$ compr., os antipétalos ca. 0,5 cm compr., glabros ou glândulas estipitadas em ambos os ciclos; conectivos prolongados abaixo das anteras, os antissépalos ca. 0,3 cm compr., os antipétalos ca. 0,2 cm compr., apêndices glabros em ambos os ciclos; anteras antissépalas ca. 1 cm compr., as antipétalas ca. 0,7 cm compr., lilás ou 


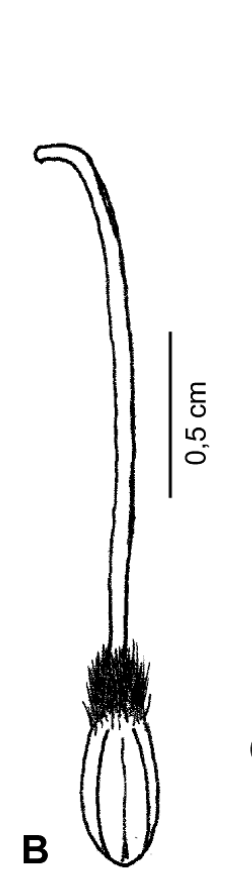

c

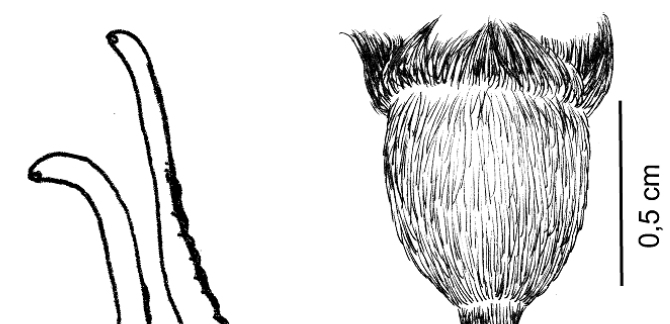

H
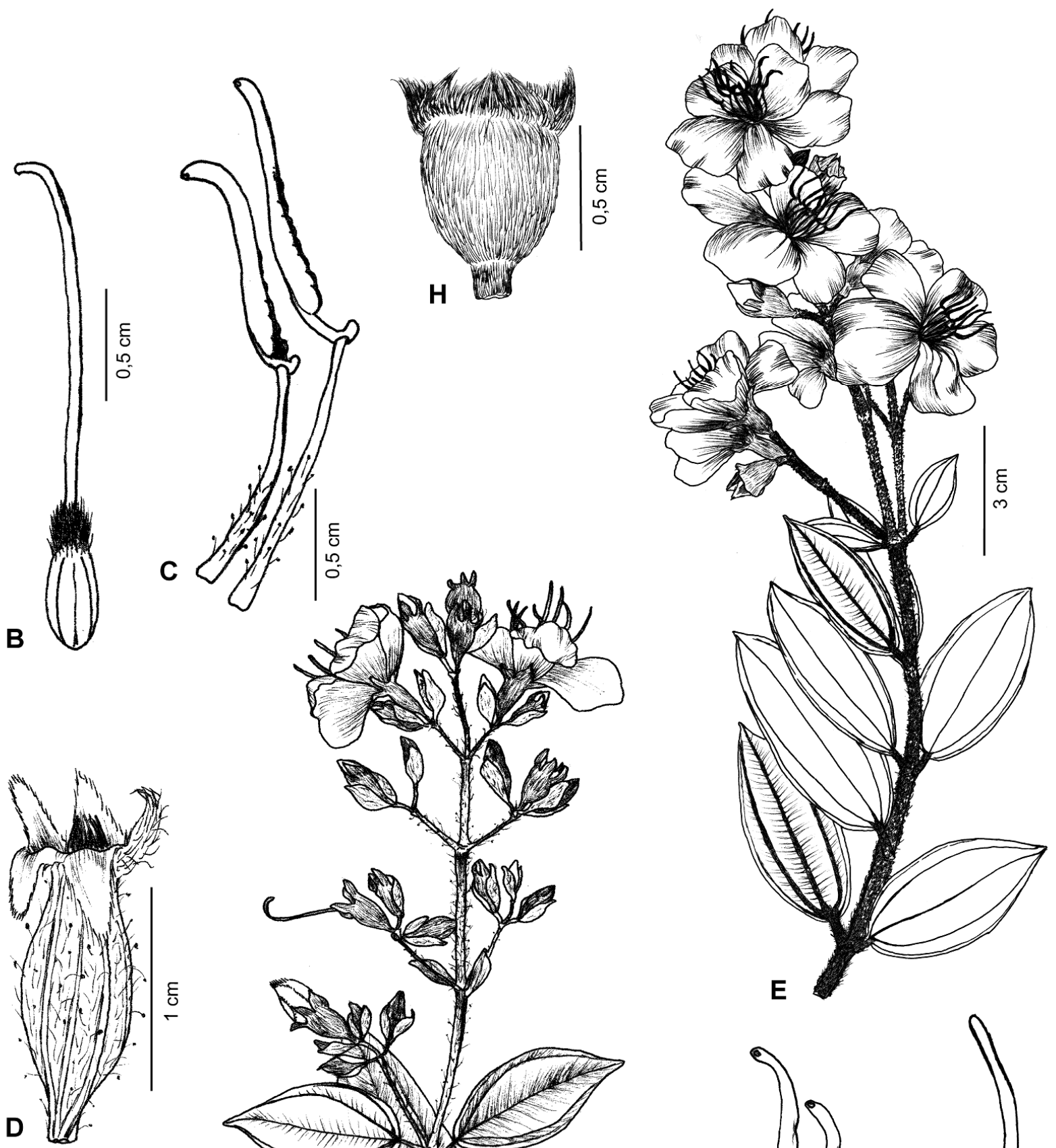

, weth
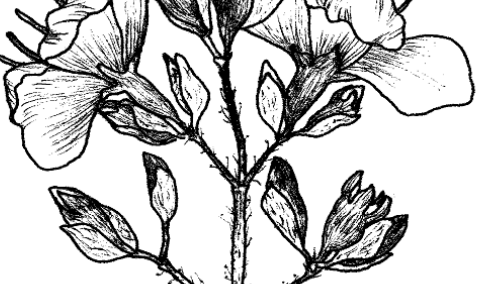


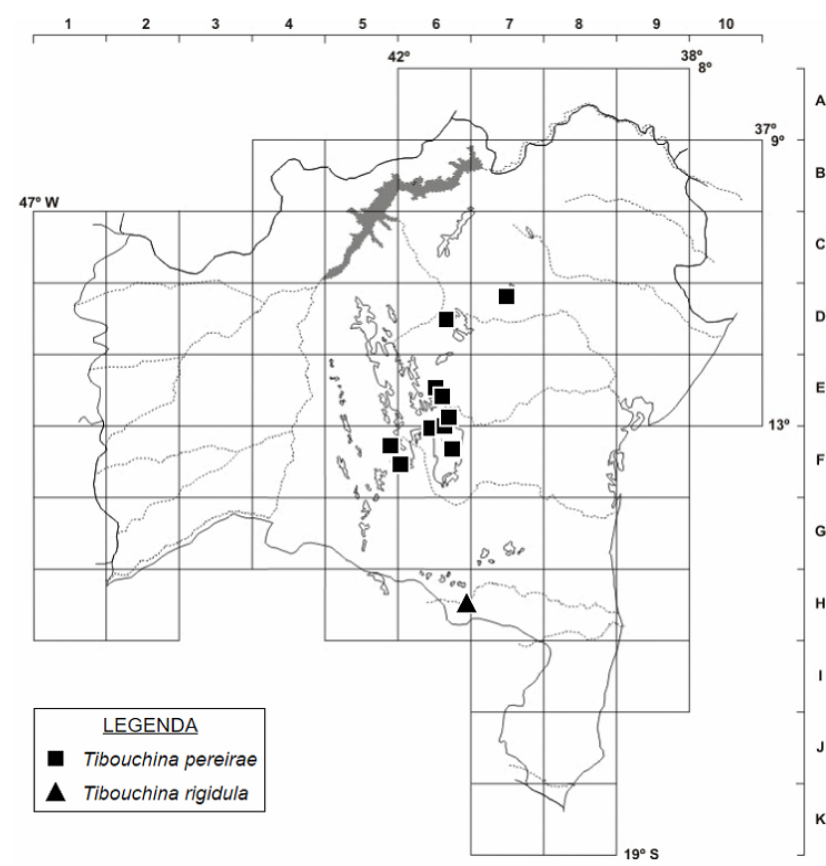

Figura 27. Mapa de distribuição geográfica de Tibouchina pereirae e $T$. rigidula no estado da Bahia.

róseas. Ovário hirsuto no ápice; estilete reto, glândulas estipitadas na metade basal; estigma punctiforme. Cápsulas ca. 1,8 ×0,6 cm, costadas.

Endêmica da Bahia (Markgraf 1927; BFG 2015), na Chapada Diamantina e bacia do Paraguaçu. F5, F7: campo rupestre, próximo a córregos, rios ou cachoeiras. Foi coletada em estágio reprodutivo de junho a outubro.

Material selecionado - Ibicoara, $13^{\circ} 18^{\prime} 56^{\prime \prime} \mathrm{S}, 41^{\circ} 09^{\prime} 38^{\prime \prime} \mathrm{W}$ 13 out. 2007 (bot. fr.), M.L. Guedes et al. 13850 (ALCB); Marcionílio Souza, Machado Portela, 19-23 jun. 1915, J.N. Rose \& P.G. Russell 19925 (M); Rio de Contas, jul. 1914, P. Luetzelburg 505 (K).

Tibouchina riparia é reconhecida pelas folhas subsésseis, inflorescências laxas, hipanto oblongo, constrito no ápice, e sépalas persistentes. Assemelha-se morfologicamente a materiais pertencentes a $T$. pereirae, inclusive pelo hábito, forma das flores e frutos, coloração, indumento e tipo de tricomas. Como salientado nos comentários de $T$. pereirae, a delimitação deste complexo de espécies carece de estudos. Ainda assim, essas duas espécies podem ser diferenciadas pelas folhas com pecíolo mais longo (0,5-1,5 cm compr.) em T. pereirae.

28. Tibouchina salviifolia (Naudin) Cogn. in Martius \& Eichler, Fl. Bras. 14(3): 364. 1885.

Figuras 28F-L e 29.

Arbusto até $2 \mathrm{~m}$ alt.; ramos distais quadrangulares, não alados, escabros, tricomas simples, ramos proximais subcilíndricos; nós circundados por coroa de tricomas. Folhas opostas; pecíolo 0,8-1 cm compr.; lâmina 3-6 × 1,3-1,6 cm, elíptico-lanceolada, coriácea, ápice agudo, base obtusa a cuneada, margem inteira, não ciliada, plana, discolor, face adaxial escabra, tricomas simples, face abaxial estrigosa, tricomas simples, 3 nervuras basais. Inflorescências terminais e axilares, raque ca. $10 \mathrm{~cm}$ compr., tricomas simples; bractéolas $1,5-1,8 \times 0,5-0,6 \mathrm{~cm}$, elípticas, não involucrais, tricomas simples. Flores 5-meras; pedicelo 0,3-0,5 cm compr.; hipanto 0,3-0,5 × ca. 0,2 cm, urceolado, estrigoso, tricomas simples; sépalas ca. 0,5 $\times 0,2 \mathrm{~cm}$, persistentes, ápice arredondado, aristado; pétalas 1,6-2 × 1,2-1,6 cm, obdeltoides, ápice truncado, lilás. Estames 10, dimorfos; filetes antissépalos ca. 1,5 cm compr., os antipétalos ca. 0,9 cm compr., glabros em ambos os ciclos; conectivos prolongados abaixo das anteras apenas no ciclo antipétalo, até $0,4 \mathrm{~cm}$, apêndices glabros em ambos os ciclos; anteras antissépalas ca. $1 \mathrm{~cm}$ compr., as antipétalas ca. 0,7 cm compr., lilás. Ovário hirsuto no ápice; estilete reto, glabro; estigma punctiforme. Cápsulas ca. $0,5 \times 0,3 \mathrm{~cm}$, não costadas.

Endêmica da Bahia (BFG 2015), no extremo sul do estado. J8: restinga. Coletada com flores em janeiro.

Material examinado - Alcobaça, $17^{\circ} 29^{\prime} \mathrm{S}, 39^{\circ} 13^{\prime} \mathrm{W}, 16$ jan. 1977 (bot., fl.), R.M. Harley 18013 (CEPEC).

Tibouchina salviifolia é reconhecida pelas folhas elíptico-lanceoladas, nitidamente discolores, com indumento escabro na face adaxial e 3 nervuras basais, e bractéolas elípticas muito longas, as quais recobrem o botão floral. É morfologicamente semelhante a $T$. luetzelburgii (veja comentários naquela espécie).

\section{Tibouchina sebastianopolitana (Raddi) Cogn. in} Martius \& Eichler, Fl. Bras. 14(3): 409. 1885. Figura 31.

Subarbusto 1-1,5 m alt.; ramos distais quadrangulares, não alados, estrigosos, glândulas estipitadas, ramos proximais subcilíndricos; nós não circundados por coroa de tricomas. Folhas opostas; pecíolo 0,3-0,6 cm compr.; lâmina 4-6,5 × 1,5-3,5 cm, oval a oblonga, membranácea, ápice agudo a acuminado, base obtusa, margem denteada, não ciliada, plana, levemente discolor; face adaxial setosa, face abaxial vilosa, tricomas simples em ambas as faces, 5 nervuras basais. Inflorescências terminais e axilares, raque 8-16 cm compr., glândulas estipitadas; bractéolas ca. $0,2 \times 0,1 \mathrm{~cm}$, triangulares, não involucrais, tricomas simples. Flores 4-meras; pedicelo 0,05-0,1 cm compr.; hipanto ca. $0,4 \times 0,2 \mathrm{~cm}$, urceolado, estrigoso, tricomas simples e glândulas estipitadas; sépalas ca. 0,2 × 0,1 cm, decíduas, ápice agudo, não aristado; pétalas ca. $0,8 \times 0,6 \mathrm{~cm}$, obovais, ápice irregular, lilás. Estames 8, dimorfos; filetes antissépalos ca. $0,7 \mathrm{~cm}$ compr., os antipétalos ca. $0,5 \mathrm{~cm}$ compr., ambos os ciclos glabros; conectivos prolongados abaixo das anteras, os antissépalos ca. 0,1 cm compr., os antipétalos ca. 0,06 cm compr., apêndices glabros em ambos os ciclos; anteras antissépalas ca. 0,5 cm compr., as antipétalas ca. 0,4 cm compr., amarelas. Ovário setuloso no ápice; estilete curvo no ápice, às vezes seríceo na porção basal; estigma punctiforme. Cápsulas ca. $0,6 \times 0,5 \mathrm{~cm}$, não costadas. 


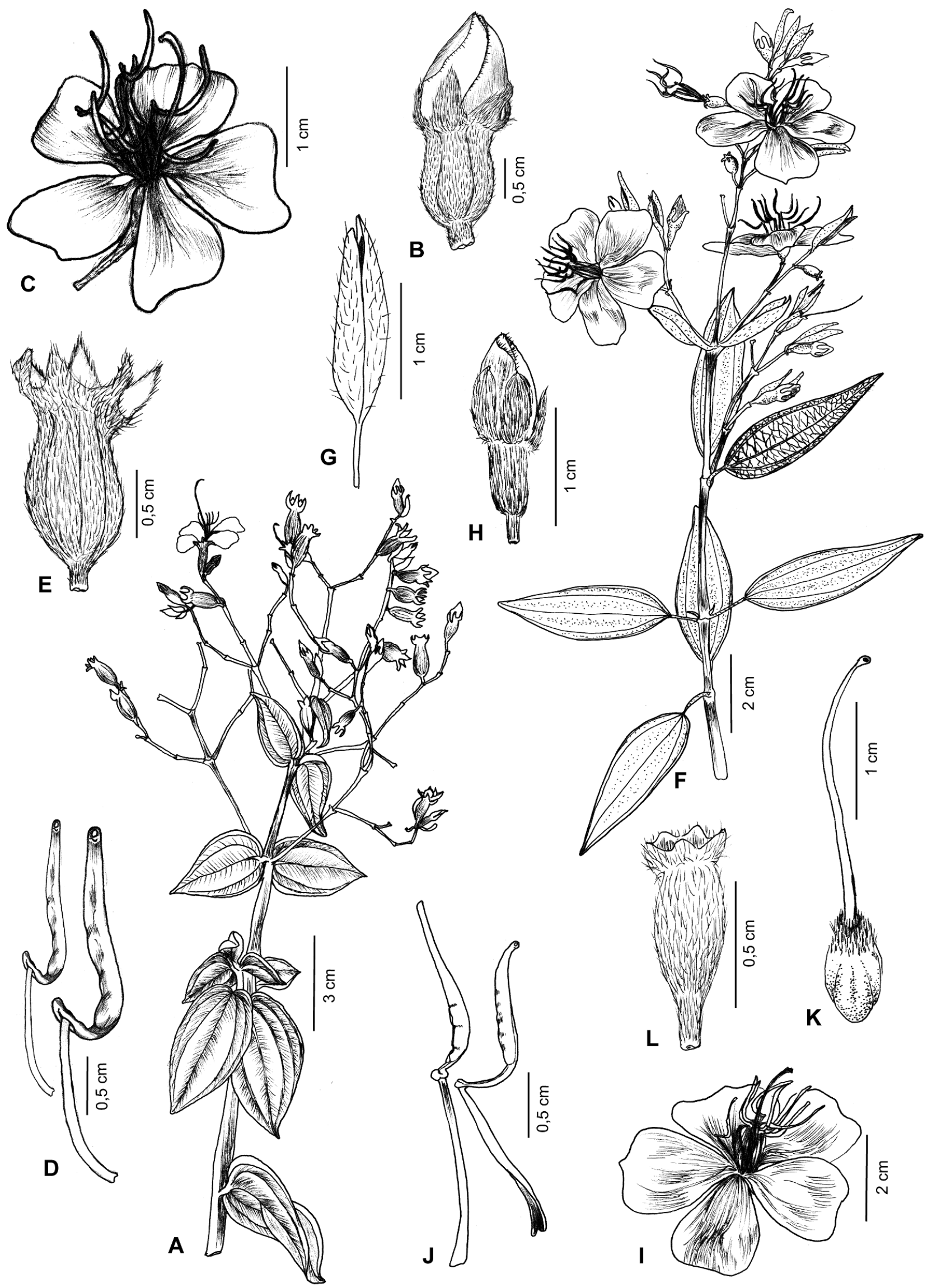

Figura 28. A-E. Tibouchina riparia: A- ramo com flor e frutos; B- botão floral; C- flor; D- estames de ambos os ciclos; E- fruto (Guedes 13923 ALCB). F-L. T. salviifolia: F- ramo com botões e flores; G- bractéolas recobrindo o botão floral; H- botão floral; I- flor; J- estames de ambos os ciclos; K- gineceu; L- fruto (Harley 18013 CEPEC). 


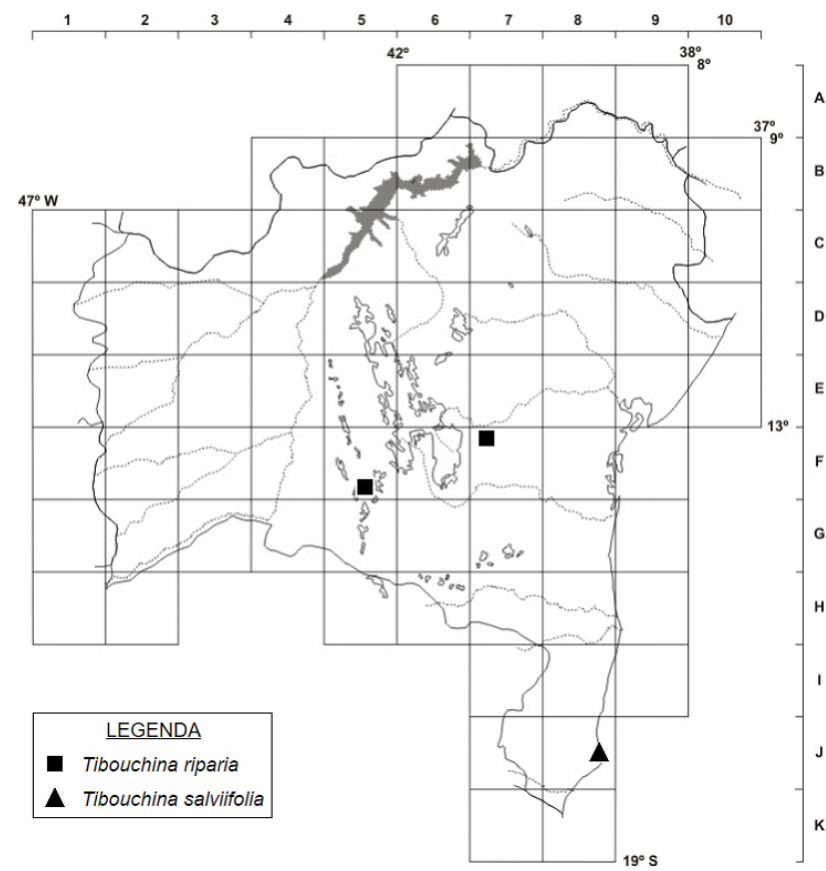

Figura 29. Mapa de distribuição geográfica de Tibouchina riparia e T. salviifolia no estado da Bahia.

Endêmica do Brasil, ocorre na Bahia, Espírito Santo, Minas Gerais, Paraná e São Paulo (Oliveira 2001; BFG 2015). F6: Chapada Diamantina, em área úmida e brejosa. Coletada com flores e frutos em junho.

Material examinado - Abaíra, Catolés de cima, Bem Querer, 9 jun. 1992 (bot., fl., fr.), W. Ganev 451 (HUEFS, K).

Tibouchina sebastianopolitana distingue-se das demais espécies do gênero na Bahia, por tratar-se de uma planta de porte subarbustivo, com ramos vináceos e flores 4-meras, com as pétalas lilás contrastando com as anteras amarelas.

30. Tibouchina stenocarpa (Schrank \& Mart. ex DC.) Cogn. in Martius \& Eichler, Fl. Bras. 14(3): 344. 1885.

Figuras 30A-F e 31.

Arvoreta 3-5 m alt.; ramos distais quadrangulares, não alados, estrigosos, tricomas dendríticos e parcialmente adpressos, ramos proximais subcilíndricos; nós não circundados por coroa de tricomas. Folhas opostas; pecíolo 1-1,5 cm compr.; lâmina $4-8 \times 1,5-2,5 \mathrm{~cm}$, elíptica, cartácea, ápice obtuso a agudo, base cuneada, margem inteira, não ciliada, plana, discolor, face adaxial estrigosa, tricomas dendríticos adpressos na metade basal, face abaxial estrigosa, tricomas simples, 5 nervuras suprabasais no último par. Inflorescências terminais, raque $6-12 \mathrm{~cm}$ compr., tricomas dendríticos; bractéolas 0,8-1,2 × 0,4$0,6 \mathrm{~cm}$, ovais, não involucrais, tricomas dendríticos. Flores 5-meras; pedicelo ca. 0,3 cm compr.; hipanto $0,4-0,6 \times 0,3-0,5 \mathrm{~cm}$, urceolado, estrigoso, tricomas dendríticos; sépalas ca. $0,5 \times 0,4 \mathrm{~cm}$, decíduas, ápice obtuso, não aristado; pétalas ca. $3,5 \times 2 \mathrm{~cm}$, obdeltoide, ápice truncado, lilás. Estames 10, dimorfos; filetes antissépalos 1,4-1,8 cm compr., os antipétalos ca. $1 \mathrm{~cm}$ compr., tricomas simples e densos em ambos os ciclos; conectivos prolongados abaixo das anteras, os antissépalos ca. 0,2 cm compr., os antipétalos ca. 0,1 cm compr., apêndices glabros em ambos os ciclos; anteras antissépalas ca. 1,2 cm compr., as antipétalas ca. $0,8 \mathrm{~cm}$ compr., lilás. Ovário hirsuto no ápice; estilete reto, glabro; estigma punctiforme. Cápsulas $0,8-1 \times 0,6-0,7 \mathrm{~cm}$, não costadas.

Conhecida para o Brasil, Bolívia e Paraguai (Matsumoto \& Martins 2005), amplamente distribuída na Bahia, Distrito Federal, Goiás, Mato Grosso, Mato Grosso do Sul, Minas Gerais, Pará, Paraná, Rondônia, Santa Catarina e São Paulo (BFG 2015). C7, F6: Chapada Diamantina e piemonte da diamantina, em cerrado e floresta estacional. Coletada em estágio reprodutivo em fevereiro e abril.

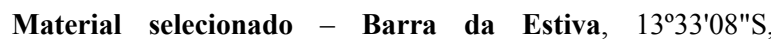
41 19'40"W, 4 abr. 2004 (bot., fl.), F. França 4944 (HUEFS); Senhor do Bonfim, 10²2' $20^{\prime \prime}$ S, 40¹2'10"W, 15 fev. 2002 (fl., fr.), R.A. Carvalho 1 (HUEFS).

Tibouchina stenocarpa é reconhecida pelas folhas adaxialmente com tricomas dendríticos e adpressos e abaxialmente com tricomas simples, estames densoseríceos, com tricomas simples, e estilete glabro. Assemelha-se morfologicamente a $T$. rigidula (veja comentários naquela espécie). Além disso, também apresenta semelhanças com $T$. taperoensis, pela forma elíptica e consistência das folhas. Contudo, esta última distingue-se pelas sépalas muito curtas, persistentes no fruto, tricomas dendríticos na face abaxial das folhas e estames isomorfos.

31. Tibouchina stipulacea Vinha, Bradea 1(30): 321. 1973.

Figuras 30G-J e 32.

Arbusto ca. $2 \mathrm{~m}$ alt.; ramos distais quadrangulares, não alados, escabros, tricomas simples ou glândulas estipitadas, ramos proximais subcilíndricos; nós circundados por coroa de tricomas. Folhas opostas; pecíolo 1,5-3 cm compr.; lâmina 5-9,5 × 2-4,5 cm, oval, membranácea, ápice acuminado, base cordada, margem inteira, não ciliada, plana, concolor, face adaxial serícea, tricomas simples, face abaxial estrigosa, glândulas estipitadas, 5 ou 7 nervuras suprabasais no último par. Inflorescências terminais, raque 5-8 cm compr., tricomas simples; bractéolas ca. $0,4 \times 0,2 \mathrm{~cm}$, elípticas, não involucrais, tricomas simples. Flores 5-meras; pedicelo 0,3-0,5 cm compr.; hipanto $0,8-1 \times 0,2-0,4 \mathrm{~cm}$, oblongo, glândulas estipitadas; sépalas ca. $0,3 \times 0,2 \mathrm{~cm}$, persistentes, ápice agudo, não aristado; pétalas 1,2-1,5 × 1-1,2 cm, obdeltoides, ápice arredondado, lilás. Estames 10, subisomorfos; filetes antissépalos ca. $1 \mathrm{~cm}$ compr., os antipétalos ca. 0,7 cm compr., glabros em ambos os ciclos; conectivos prolongados abaixo das anteras, os antissépalos ca. 0,3 cm compr., os antipétalos ca. 0,1 cm compr., apêndices glabros em ambos os ciclos; anteras antissépalas ca. $1 \mathrm{~cm}$ compr., as antipétalas ca. $0,8 \mathrm{~cm}$ compr., lilás. Ovário com glândulas estipitadas 


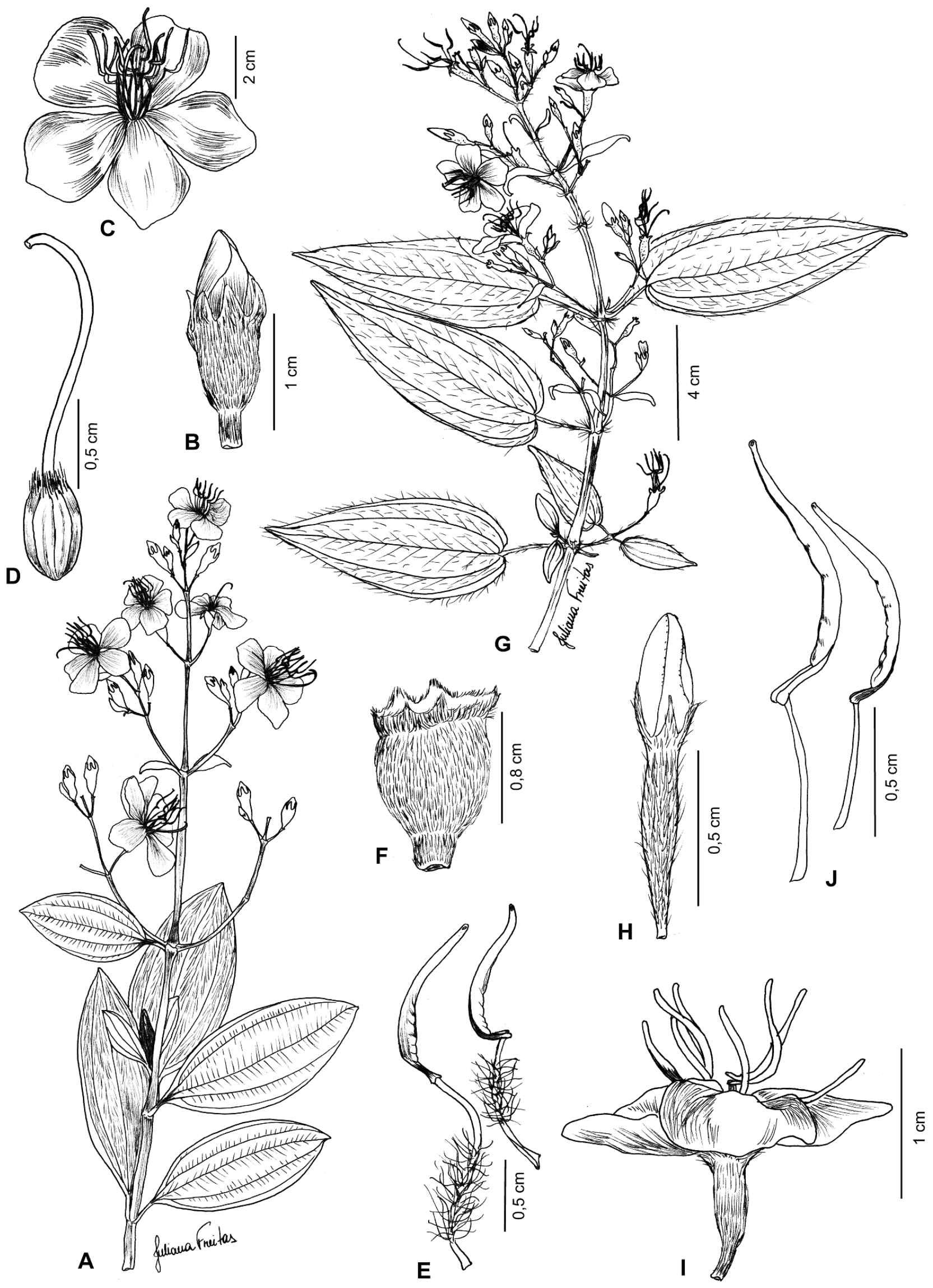

Figura 30. A-F. Tibouchina stenocarpa: A- ramo com botões e flores; B- botão floral; C- flor; D- gineceu; E- estames de ambos os ciclos; F- fruto (França 4944 HUEFS). G-J. T. stipulacea: G- ramo com botões e flores; H- botão floral; I- flor; J- estames de ambos os ciclos (Tamon 1684 CEPEC). 


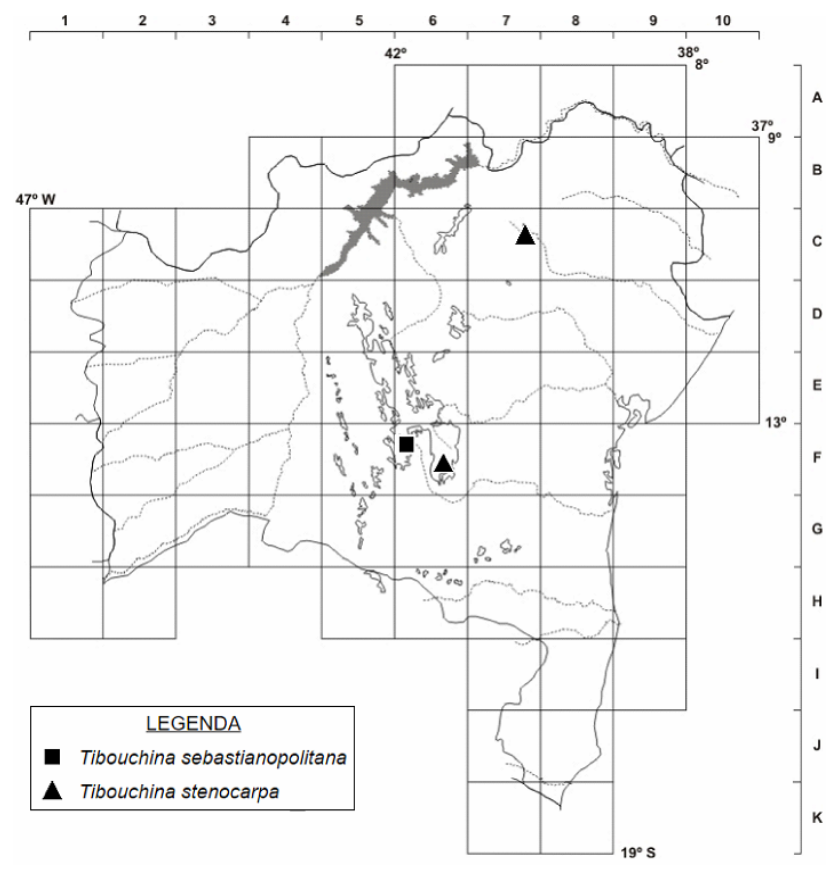

Figura 31. Mapa de distribuição geográfica de Tibouchina sebastianopolitana e T. stenocarpa no estado da Bahia.

no ápice; estilete reto, glândulas estipitadas na porção basal; estigma punctiforme. Cápsulas ca. 0,9 ×0,4 cm, não costadas.

Endêmica do Brasil, ocorre na Bahia e Espírito Santo (BFG 2015). H8: sudeste do estado, em floresta ombrófila. Coletada com flores em maio.

Material examinado - s. mun., rio Jequitionha, BR-101, 22 maio 1971 (bot., fl.), T. S. Talmon 1684 (CEPEC).

Tibouchina stipulacea é reconhecida pelas folhas membranáceas, nós circundados por uma coroa de tricomas e ápice do ovário com tricomas glandulares. Assemelha-se a $T$. pauloalvinii (veja comentários naquela espécie). Na Bahia, é conhecida apenas pelo material-tipo.

32. Tibouchina subglabra Wurdack, Phytologia 53(2): 133. 1983.

Figuras 32 e 33A, B.

Arbusto ca. 1,5 $\mathrm{m}$ alt.; ramos distais quadrangulares, não alados, glabros ou com glândulas sésseis, ramos proximais cilíndricos; nós não circundados por coroa de tricomas. Folhas opostas; pecíolo 0,3-0,8 cm compr.; lâmina 2,5-5 × 1,5-3,5 cm, oval, coriácea, ápice agudo, base cordada, margem inteira a levemente ondulada, não ciliada, plana, discolor, face adaxial glabra ou com glândulas globosas sésseis na superfície foliar, face abaxial estrigosa, tricomas simples e glândulas globosas sésseis, 5 ou 7 nervuras basais. Inflorescências terminais, raque ca. $8 \mathrm{~cm}$ compr., glabras; bractéolas não vistas. Flores 5-meras; pedicelo ca. 0,3 cm compr.; hipanto $0,6-0,8 \times \mathrm{ca}$. $0,4 \mathrm{~cm}$, urceolado, estrigoso, tricomas simples; sépalas ca. $0,3 \times 0,2 \mathrm{~cm}$, persistentes, ápice agudo, não aristado; pétalas $1-1,2 \times 0,8-1 \mathrm{~cm}$, obdeltoides, ápice arredondado, lilás. Estames 10, subisomorfos; filetes antissépalos ca. $1 \mathrm{~cm}$ compr., os antipétalos ca. 0,7 cm compr., ambos os ciclos glabros; conectivos prolongados abaixo das anteras apenas no ciclo antipétalo, ca. 0,2 cm compr., apêndices glabros em ambos os ciclos; anteras antissépalas ca. 0,9 cm compr., as antipétalas até $0,8 \mathrm{~cm}$ compr., lilás. Ovário com 3 a 6 glândulas estipitadas no ápice; estilete curvo, glabro; estigma punctiforme. Cápsulas ca. $0,7 \times 0,5$ $\mathrm{cm}$, levemente costadas.

Endêmica da Bahia (BFG 2015), na Chapada Diamantina. D6: campo rupestre. Coletada com flores e frutos em maio.

Material examinado - Morro do Chapéu, Rio do Ferro Doido, $11^{\circ} 38^{\prime} \mathrm{S}, 41^{\circ} 32^{\prime} \mathrm{W}, 31$ maio 1980 (bot., fl., fr.), R.M. Harley 22895 (CEPEC).

Tibouchina subglabra é conhecida apenas pelo material-tipo, sendo caracterizada pelos ramos distais e folhas com glândulas globosas, face adaxial da lâmina foliar glabra e a abaxial estrigosa, com tricomas simples, e o ovário com algumas glândulas estipitadas no ápice. Dentre as espécies de Tibouchina da Bahia, possui algumas semelhanças com $T$. tomentulosa, pelo hábito arbustivo com ramos em ângulos abertos $\left(>45^{\circ}\right)$ e folhas glabrescentes adaxialmente. Essas espécies diferem, no entanto, pela presença de glândulas estipitadas no hipanto, sépalas e estilete em $T$. tomentulosa, e ausência de tricomas no ovário de $T$. subglabra.

33. Tibouchina taperoensis Wurdack, Phytologia 64(4): 295.1988.

Figuras $33 \mathrm{C}-\mathrm{G}$ e 34 .

Arbusto 1,5-2 m alt.; ramos distais quadrangulares, não alados, escabros, tricomas dendríticos, ramos proximais cilíndricos; nós não circundados por coroa

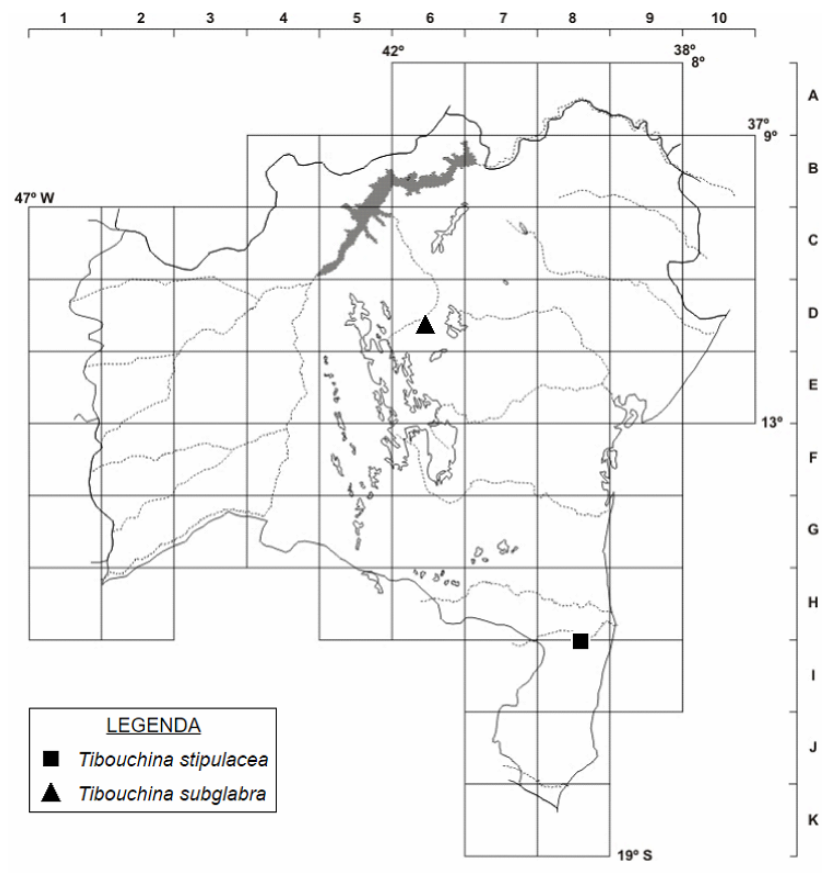

Figura 32. Mapa de distribuição geográfica de Tibouchina stipulacea e T. subglabra no estado da Bahia. 


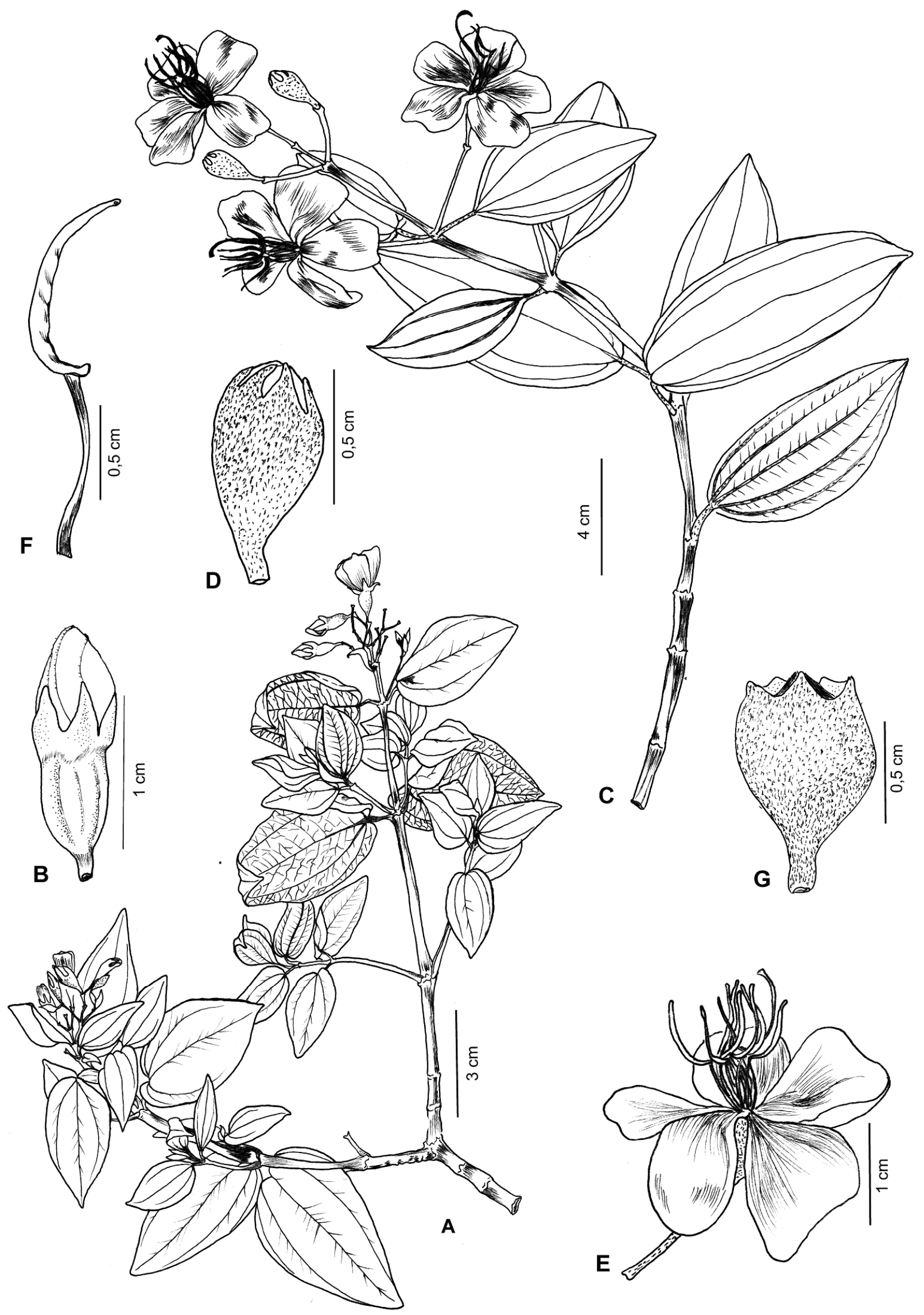

Figura 33. A, B. Tibouchina subglabra: A- ramo com botões; B- botão floral (Harley 22895 CEPEC). C-G. T. taperoensis: C- ramo com botões e flores; D- botão floral evidenciando sépalas curtas; E- flor; F- estame; G- fruto (Carvalho 354 HRB). 
de tricomas. Folhas opostas; pecíolo 1-1,5 cm compr.; lâmina $6-8,5 \times 2,3-2,8 \mathrm{~cm}$, elíptica, coriácea, ápice apiculado, base obtusa, margem inteira, não ciliada, plana, discolor, estrigosa em ambas as faces, tricomas dendríticos, 5 nervuras basais. Inflorescências terminais, raque 10-12 cm compr., tricomas dendríticos; bractéolas não vistas. Flores 5-meras; pedicelo ca. 0,4 cm compr.; hipanto $0,8-1 \times 0,6-0,8$ $\mathrm{cm}$, campanulado, estrigoso, tricomas dendríticos; sépalas ca. $0,2 \times 0,1 \mathrm{~cm}$, persistentes, ápice arredondado, não aristado; pétalas 1,8-2 × 1,3-1,5 cm, obdeltoides, ápice truncado, lilás. Estames 10, isomorfos; filetes $0,9-1,1 \mathrm{~cm}$ compr., glabros, raro com tricomas simples; conectivos não prolongados abaixo das anteras, apêndices glabros; anteras ca. 1,3 $\mathrm{cm}$ compr. Ovário hirsuto no terço apical; estilete curvo no ápice, glabro; estigma punctiforme. Cápsulas $0,4-0,6 \times$ ca. $0,5 \mathrm{~cm}$, não costadas.

Endêmica da Bahia (BFG 2015), no litoral sul. F8: restinga. Coletada com flores de dezembro a fevereiro.

Material examinado - Taperoá, ramal de fazendas a oeste de Taperoá, 4-7 km da cidade, 8 dez. 1980 (bot., fl., fr.), A.M. Carvalho et al. 354 (CEPEC, HRB, HUEFS); Valença, BR-101, próximo ao entroncamento da cidade, s.d. (fl.), G.C.P. Pinto s.n. (ALCB, HRB 23386, HUEFS).

Tibouchina taperoensis é reconhecida pelo hipanto campanulado, com tricomas dendríticos, sépalas muito curtas, persistentes no fruto, e filetes glabros. A forma e consistência das folhas a assemelha com $T$. stenocarpa (veja comentários naquela espécie).

34. Tibouchina tomentulosa Wurdack, Kew Bull. 50(4): 824.1995.

Figuras 34 e $35 \mathrm{~A}-\mathrm{D}$.

Arbusto 1,5- $2 \mathrm{~m}$ alt.; ramos distais quadrangulares, não alados, estrigosos, tricomas simples e glândulas pediceladas, ramos proximais cilíndricos; nós não circundados por coroa de tricomas. Folhas opostas; pecíolo 1,2-3 cm compr.; lâmina 4,5-7 × 2,5-4 cm, elíptica a cordada, coriácea, ápice apiculado, base subcordada, margem inteira, não ciliada, plana, discolor, face adaxial glabra, face abaxial tomentosa, tricomas simples, 5 nervuras suprabasais no último par. Inflorescências terminais, raque 6-12 cm compr., tricomas simples; bractéolas não vistas. Flores 5-meras; pedicelo ca. 0,3 cm compr.; hipanto $0,8-1 \times 0,3-0,4 \mathrm{~cm}$, oblongo, seríceo, tricomas simples e glândulas estipitadas; sépalas $0,3-0,4 \times 0,2-0,3 \mathrm{~cm}$, decíduas, ápice agudo, não aristado; pétalas 1,7-2 × 0,8-1 cm, obdeltoides, ápice arredondado, lilás. Estames 10, subisomorfos; filetes antissépalos ca. 1,5 cm compr., os antipétalos ca. $0,9 \mathrm{~cm}$ compr., ambos os ciclos glabros; conectivos prolongados abaixo das anteras, os antissépalos ca. 0,3 cm compr., os antipétalos ca. 0,1 cm compr., apêndices glabros em ambos os ciclos; anteras antissépalas ca. 1 cm compr., as antipétalas ca. $0,8 \mathrm{~cm}$ compr. Ovário hirsuto no terço apical; estilete reto, glândulas estipitadas na porção basal; estigma punctiforme. Cápsulas $0,7-1 \times$ ca. $0,6 \mathrm{~cm}$, não costadas.

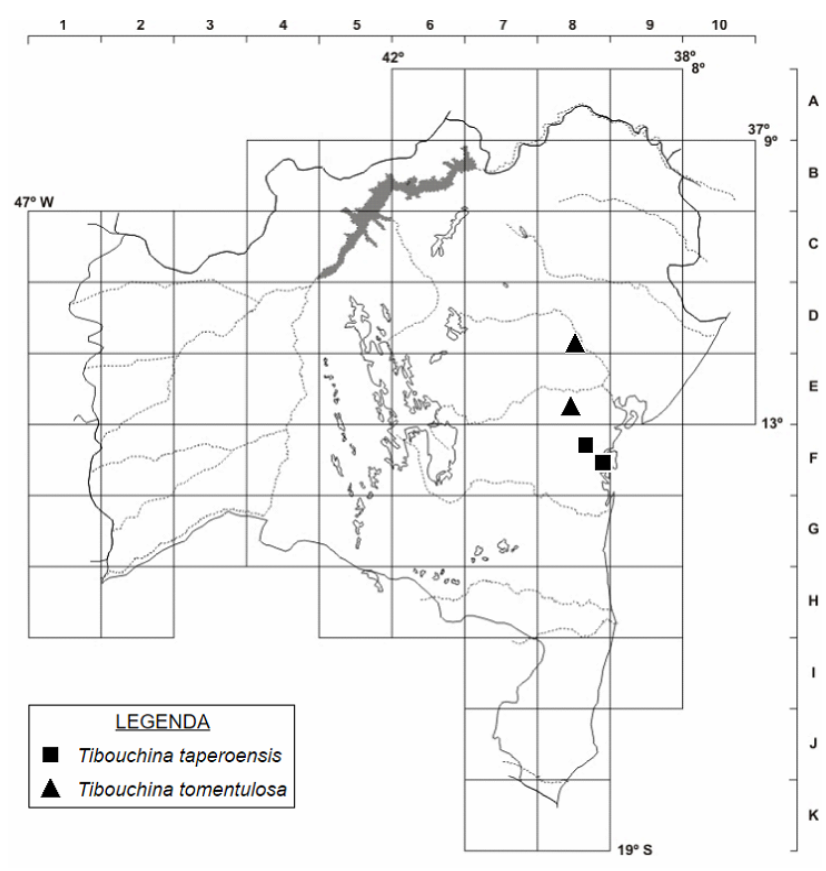

Figura 34. Mapa de distribuição geográfica de Tibouchina taperoensis e T. tomentulosa no estado da Bahia.

Endêmica da Bahia (BFG 2015), no recôncavo sul. D8, E8: cerrado. Coletada em estágio reprodutivo de maio a dezembro.

Material selecionado - Castro Alves, $12^{\circ} 51^{\prime} 11$ "S, 39²8'19"W, 7 maio 1993 (fl.), L.P. Queiroz et al. 3132 (ALCB, HUEFS); Santa Terezinha, 12 $2^{\circ} 45^{\prime} \mathrm{S}, 39^{\circ} 32^{\prime} \mathrm{W}, 1$ jun. 1996 (bot., fl.), A. Souza et al. 11 (HUEFS, HUNEB).

Reconhecida pelas folhas congestas nos ramos distais com face adaxial glabra e face abaxial tomentosa, com nervuras escuras e proeminentes, além dos filetes glabros e estilete com glândulas estipitadas no terço basal. Assemelha-se a T. subglabra (veja comentários naquela espécie).

35. Tibouchina urceolaris (Schrank \& Mart. ex DC.) Cogn. in Martius \& Eichler., Fl. Bras. 14(3): 355. 1885.

Figuras 1Y, 35E-I e 37.

Arbusto 1-2 m alt.; ramos distais e proximais quadrangulares, levemente alados, estrigosos, tricomas dendríticos; nós não circundados por coroa de tricomas. Folhas opostas; pecíolo 0,5-1 cm compr.; lâmina 4-7,5 × 1,7-4,3 cm, elíptica, coriácea, ápice agudo, base obtusa a subcordada, margem inteira, não ciliada, plana, discolor, estrigosa em ambas as faces, tricomas dendríticos, 5 nervuras basais. Inflorescências terminais, raque $12-20 \mathrm{~cm}$ compr., tricomas dendríticos; bractéolas 0,4-1,2 ×0,4-0,8 cm, elípticas, não involucrais, tricomas simples. Flores 5meras; pedicelo $0,1-0,2 \mathrm{~cm}$ compr.; hipanto $0,6-0,8 \times$ 0,2-0,3 cm, oblongo, estrigoso, tricomas dendríticos; sépalas $0,2-0,3 \times 0,1-0,2 \mathrm{~cm}$, decíduas, ápice apiculado, não aristado; pétalas 1,5-1,7 × 0,8-1 cm, obdeltoides, ápice arredondado, lilás. Estames 10, subisomorfos; filetes antissépalos ca. 1,5 cm compr., os 

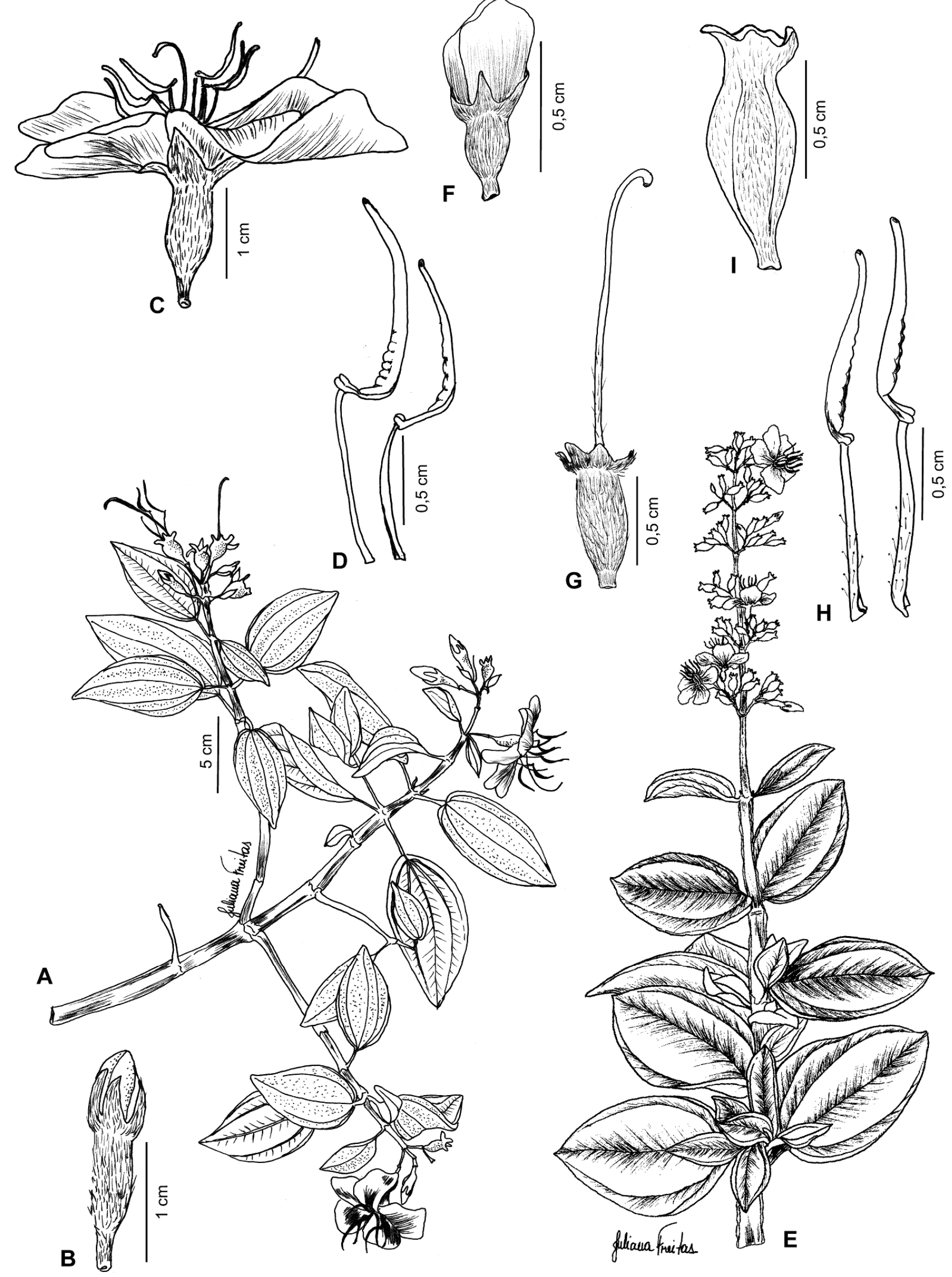

Figura 35. A-D. Tibouchina tomentulosa: A- ramo com botões e flores; B- botão floral; C- flor; D- estames de ambos os ciclos ( Queiroz 3132 HUEFS). E-I. T. urceolaris: E- ramo com flores e frutos; F- botão floral; G- hipanto evidenciando estilete longo e curvo no ápice; H- estames de ambos os ciclos; I- fruto (Guedes 12192 ALCB). 
antipétalos ca. 1 cm compr., glândulas estipitadas ou raramente glabros em ambos os ciclos; conectivos prolongados abaixo das anteras, os antissépalos ca. 0,3 cm compr., os antipétalos ca. 0,1 cm compr., apêndices glabros em ambos os ciclos; anteras antissépalas ca. $0,9 \mathrm{~cm}$ compr., as antipétalas ca. $0,7 \mathrm{~cm}$ compr., lilás. Ovário hirsuto no terço apical, raro com tricomas glandulares; estilete reto, glândulas estipitadas na base; estigma punctiforme. Cápsulas $0,8-1 \times$ ca. $0,5 \mathrm{~cm}$, semicostadas.

Endêmica do Brasil, ocorre na Bahia, Espírito Santo e Rio de Janeiro (BFG 2015). D7, D10, E9, E10, G8, H8: litoral norte, litoral sul, recôncavo sul, piemonte da diamantina e região metropolitana de Salvador, em restinga ou cerrado. Coletada em estágio reprodutivo em vários meses do ano.

Material selecionado - Camaçari, $12^{\circ} 26^{\prime} \mathrm{S}, 38^{\circ} 44^{\prime} \mathrm{W}, 3 \mathrm{fev}$ 2006 (fl., fr.), D. Cardoso 1045 (HUEFS); Conde, 11\%48'S, $37^{\circ} 36^{\prime} \mathrm{W}, 3$ nov. 2001 (bot., fr.), D.L. Santana et al. 655 (ALCB); Entre Rios, $12^{\circ} 18^{\prime} 54^{\prime \prime S}, 37^{\circ} 49^{\prime} 53^{\prime \prime W}, 17$ nov. 2005 (bot., fr.), S.F. Conceição 398 (HUEFS); Esplanada, 12²6'S, 3844'W, 23 maio

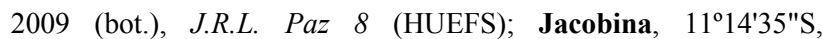
4043'48"W, 31 mar. 1996 (bot., fl.), A.M. Giulietti PCD 2680 (ALCB, HUEFS); Maraú, 14¹4'35"S, 3900'51"W, 29 dez. 2005 (fl., fr.), A.K.A. Santos 538 (HUEFS); Mata de São João, $12^{\circ} 28^{\prime} 13 " \mathrm{~S}, 37^{\circ} 57^{\prime} 43^{\prime \prime W}, 18$ nov. 2005 (fl., fr.), A.K.A. Santos 494 (HUEFS); Prado, 15 $40^{\circ} \mathrm{S}, 38^{\circ} 59^{\prime} \mathrm{W}, 3$ maio 2005 (fr.), P.P. Oliveira 89 (HUEFS); Salvador, 1256'S, 38²1'W, 16 mar. 1980 (bot., fl.), L.R. Noblick 1733 (ALCB, HUEFS); Una, 15¹9'58"S, 39³'18"W, 18 nov. 1995 (bot., fr.), W.W. Thomas 11041 (ALCB, HUEFS).

Tibouchina urceolaris é reconhecida pelas cápsulas urceoladas, inflorescências pouco ramificadas, além das folhas com tricomas dendríticos (com projeções curtas). É semelhante a um dos morfotipos de $T$. pereirae, pelo hábito arbustivo, com folhas de consistência coriácea, densas nos ramos distais, distinguindo-se pelas inflorescências laxas e ramos da inflorescência e flores com glândulas estipitadas em $T$. pereirae.

36. Tibouchina velutina (Naudin) Cogn. in Martius \& Eichler, Fl. Bras. 14(3): 350. 1885.

Figuras 1Z, 36A-D e 37.

Subarbusto ou arbusto 0,5-2 $\mathrm{m}$ alt.; ramos distais quadrangulares, não alados, estrigosos, tricomas simples, ramos proximais cilíndricos; nós não circundados por coroa de tricomas. Folhas opostas; pecíolo 0,3-0,6 cm compr.; lâmina 2,4-4 × 1,5-2 cm, elíptica a oval, coriácea, ápice apiculado, base obtusa, margem inteira, não ciliada, plana, discolor, serícea em ambas as faces, tricomas simples, 5 nervuras basais. Inflorescências terminais, raque $5-12 \mathrm{~cm}$ compr., tricomas simples; bractéolas $0,3-0,5 \times$ ca. $0,3 \mathrm{~cm}$, elípticas, não involucrais, tricomas simples. Flores 5meras; pedicelo 0,1-0,3 cm compr.; hipanto ca. $0,8 \times$ $0,4 \mathrm{~cm}$, urceolado, seríceo, tricomas simples; sépalas ca. $0,8 \times 0,4 \mathrm{~cm}$, decíduas, ápice apiculado, não aristado; pétalas 1,7-2 × 1-1,3 cm, obdeltoides, ápice truncado, lilás. Estames 10, dimorfos; filetes antissépalos ca. 1,5 cm compr., os antipétalos ca. $1 \mathrm{~cm}$ compr., glabros ou raramente com glândulas estipitadas em ambos os ciclos; conectivos prolongados abaixo das anteras apenas no ciclo antissépalo, ca. 0,2 cm compr., apêndices glabros em ambos os ciclos; anteras antissépalas ca. $1,1 \mathrm{~cm}$ compr., as antipétalas ca. 0,8 cm compr., lilás ou róseas. Ovário hirsuto no terço apical; estilete curvo no ápice, tricomas simples na metade apical; estigma punctiforme. Cápsulas $0,6-0,8 \times$ ca. $0,5 \mathrm{~cm}$, não costadas.

Endêmica da Bahia (BFG 2015), na Chapada Diamantina e piemonte da diamantina. C6, C7, E6, F6: cerrado, especialmente em campo rupestre. Coletada em estágio reprodutivo de fevereiro a outubro.

Material selecionado - Abaíra, $13^{\circ} 14^{\prime} \mathrm{S}, 41^{\circ} 54^{\prime} \mathrm{W}, 5$ maio 1992 (bot., fl.), W. Ganev 233 (HUEFS); Campo Formoso, $10^{\circ} 30^{\prime} 49^{\prime \prime S}, 40^{\circ} 18^{\prime} 25^{\prime \prime W}, 14$ ago. 1999 (fl., fr.), E.B. Miranda 162 (HUEFS); Igatu, 12 $50^{\prime} 11^{\prime \prime S}, 41^{\circ} 19^{\prime} 19^{\prime \prime} \mathrm{W}, 5$ abr. 2005 (fl.), A.K.A. Santos 268 (HUEFS); Jacobina, $11^{\circ} 00^{\prime} 50^{\prime \prime} \mathrm{S}, 40^{\circ} 00^{\prime} 40^{\prime \prime} \mathrm{W}, 26$ nov. 2003 (bot., fl.), A.M. Amorim et al. 3836 (CEPEC); Lençóis, $12^{\circ} 34^{\prime} \mathrm{S}, 4^{\circ} 23^{\prime} \mathrm{W}, 1$ out. 1982 (fr.), C.M.B. Lôbo 29 (HUEFS); Palmeiras, $12^{\circ} 36^{\prime} 01^{\prime \prime S}, 41^{\circ} 27^{\prime} 17^{\prime \prime} \mathrm{W}, 11$ out. 1987 (bot.), L.P. Queiroz 1915 (HUEFS); Pindobaçu, 1066'S, 40²2'W, 10 mar. 1981 (fl., fr.), R.P. Orlandi 335 (CEPEC, HRB); Rio de Contas,

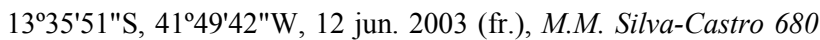

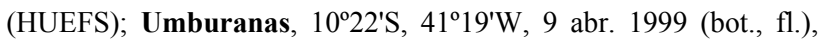
L.P. Queiroz 5129 (HUEFS).

Tibouchina velutina é reconhecida pelas folhas seríceas com tricomas simples e esbranquiçados, dando aspecto acinzentado à lâmina com margens avermelhadas. Assemelha-se a T. blanchetiana, pelo hábito arbustivo, indumento, consistência e coloração das folhas, distinguindo-se pela forma cordada das folhas, frequentemente verticiladas, geralmente subsésseis ou com pecíolos muito curtos em $T$. blanchetiana. Além disso, possui semelhança com um dos morfotipos de $T$. pereirae, devido à forma e consistência coriácea das folhas com margens avermelhadas, distinguindo-se pelos tricomas glandulares nos ramos distais, inflorescências e hipanto em $T$. pereirae. Assemelha-se também a T. lhotzkyana (veja comeários naquela espécie).

\section{Tibouchina sp.}

Figuras 36E-H e 37.

Arbusto ca. 1,6 m alt.; ramos distais subcilíndricos, não alados, adpresso-escabros, tricomas dendríticos, ramos proximais cilíndricos; nós não circundados por coroa de tricomas. Folhas opostas; pecíolo 0,4-0,6 cm compr.; lâmina 2,5-4 × 2-2,5 cm, oval, coriácea, ápice agudo ou acuminado, base obtusa, margem inteira, não ciliada, plana, discolor, adpresso-escabra em ambas as faces, tricomas dendríticos, 5 nervuras basais. Inflorescências terminais, raque ca. $10 \mathrm{~cm}$ compr., tricomas dendríticos; bractéolas ca. $0,4 \times 0,3 \mathrm{~cm}$, elípticas, não involucrais, tricomas dendríticos. Flores em botões jovens; pedicelo $0,1-0,3 \mathrm{~cm}$ compr.; hipanto 

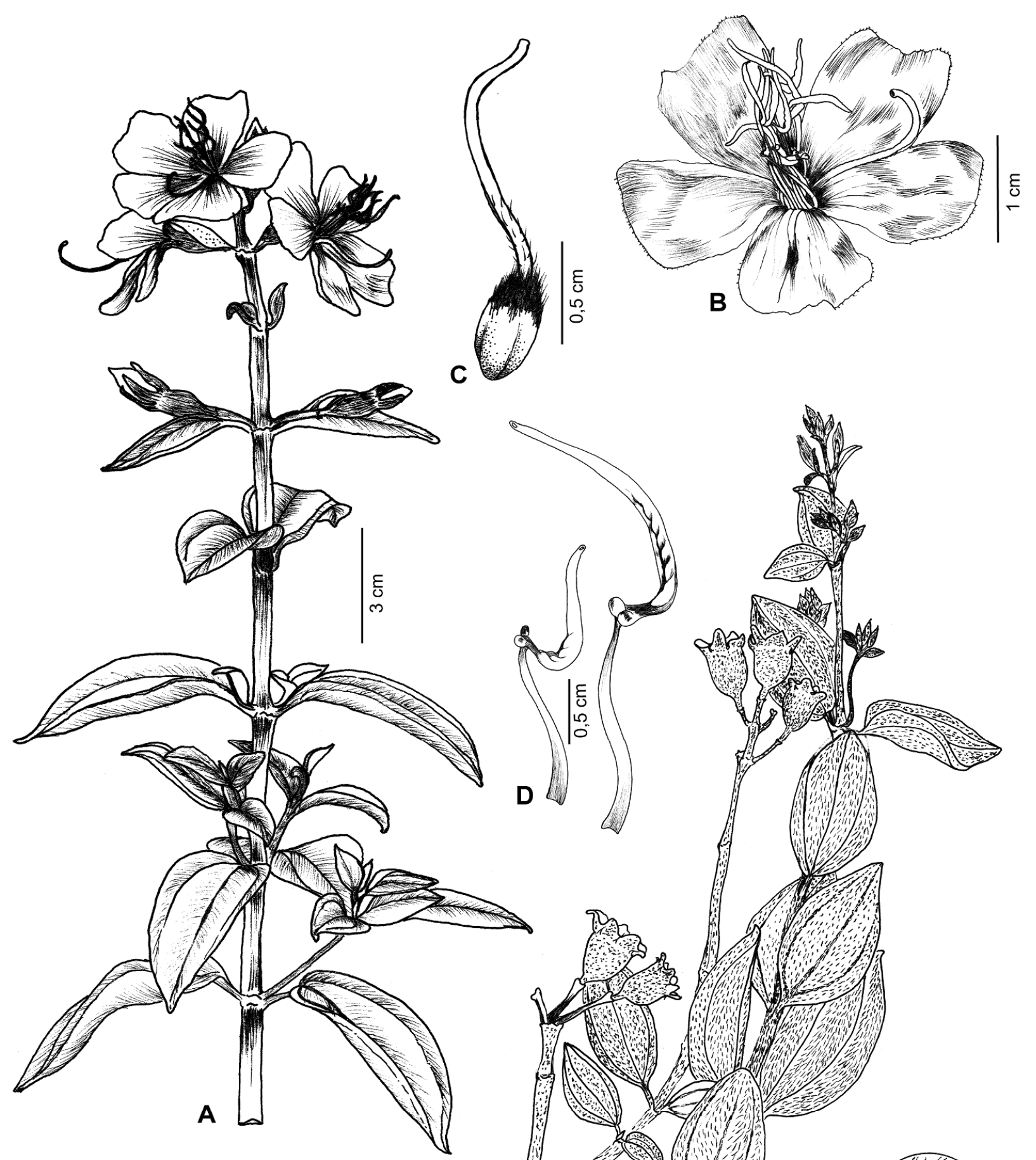

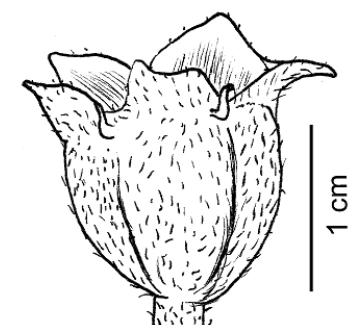

H
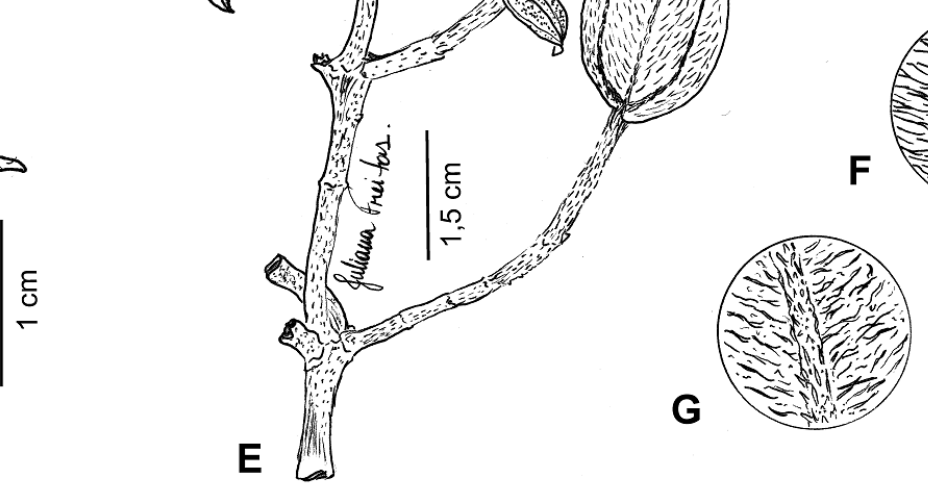

Figura 36. A-D. Tibouchina velutina: A- ramo com flores; B- flor; C- gineceu; D- estames de ambos os ciclos (Sousa 251 HUEFS). E-H. Tibouchina sp.: E- ramo com botões e frutos; F- indumento da face abaxial da lâmina foliar; G- indumento da face adaxial da lâmina foliar; H- fruto com sépalas persistentes e tricomas alternissépalos (Passos 367 HUEFS). 


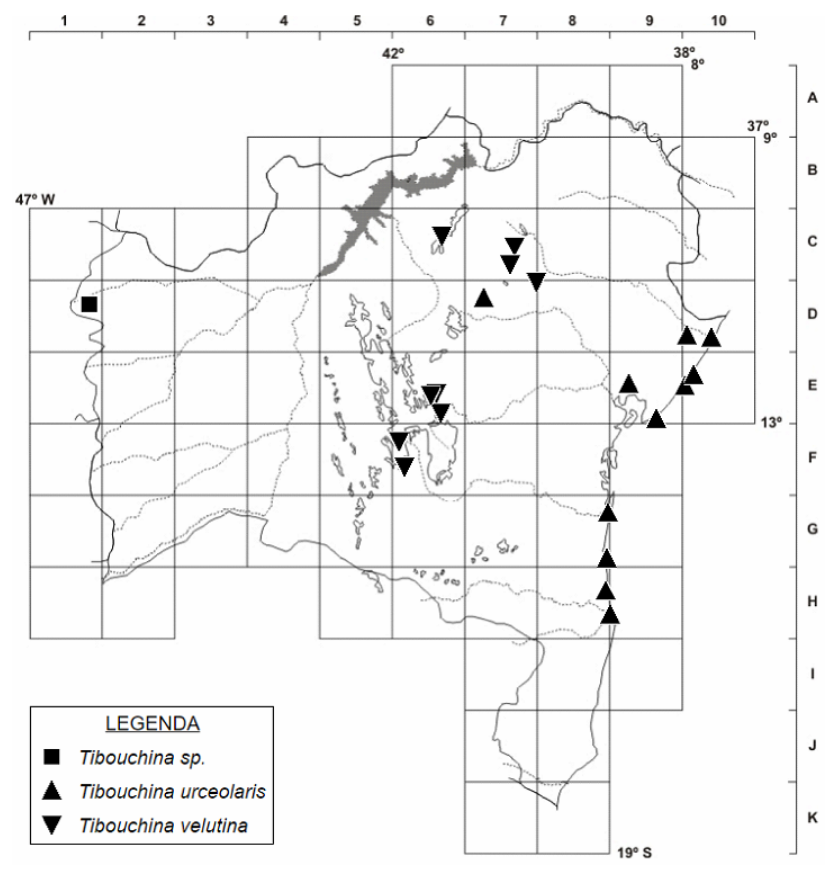

Figura 37. Mapa de distribuição geográfica de Tibouchina sp., $T$. urceolaris e T. velutina no estado da Bahia.

urceolado nos botões, adpresso-escabro, tricomas dendríticos; sépalas ca. $0,4 \times 0,6 \mathrm{~cm}$, persistentes, ápice apiculado, não aristado; pétalas não vistas; filetes não vistos; conectivos e apêndices não vistos; anteras não vistas; ovário não visto; estilete e estigma não vistos. Cápsulas ca. $1,4 \times 0,8-1 \mathrm{~cm}$, não costadas, tricoma alternissépalo simples.

Distribuição duvidosa. D1: cerrado antropizado, no oeste do estado. Coletada com flores e botões em fevereiro; provavelmente floresce em março.

Material examinado - Formosa do Rio Preto, $11^{\circ} 21^{\prime} 4^{\prime \prime} \mathrm{S}$, 46ำ' $45^{\prime \prime} \mathrm{W}, 3$ fev. 2000 (bot., fr.), L. Passos et al. 367 (CEN, CEPEC, HRB, HUEFS, HUNEB).

Essa espécie é claramente distinta das demais Tibouchina pelas folhas com indumento adpressoescabro e tricomas dendríticos parcialmente adpressos, além do caule com córtex decorticante. Por essas características, assemelha-se às espécies de Tibouchina sect. Barbigerae Naudin, porém é necessário o exame das flores para uma caracterização precisa e identificação segura da espécie.

\section{AgRADECIMENTOS}

Os autores agradecem à Universidade Estadual de Feira de Santana (UEFS) e ao Programa de Pósgraduação em Botânica, pela infraestrutura disponibilizada para a execução deste trabalho; aos curadores dos herbários consultados, pelo acesso às coleções; à Catrine A. Ferreira, pelo auxílio com a padronização das descrições; à CAPES e ao $\mathrm{CNPq}$, respectivamente, pelas bolsas concedidas a JGF (mestrado) e RPO (PQ1D); ao CNPq, pelo apoio financeiro aos Programas Flora da Bahia (processos 562278/2010-9 e 483909/2012-2) e PPBIO Semiárido; e também à FAPESB, pelo apoio nos processos APR 162/2007, PPP T.O. 038/2011, PNE 0020/2011 e PNX0014/2009.

\section{REFERÊNCIAS}

Almeda, F. 2009. Melastomataceae. In: G. Davidse, M. SousaSánchez, S. Knapp \& F. Chiang (eds), Flora Mesoamericana. Vol. 4. Universidad Nacional Autónoma de México, México City, p. 164-338.

Baumgratz, J.F.A.; Caddah, M.K.; Chiavegatto, B.; Goldenberg, R.; Guimarães, P.J.F.; Koschnitzke, C.; Kriebel, R.; Lima, L.F.G.; Martins, A.B.; Michelangeli, F.A.; Reginato, M.; Rocha, M.J.R.; Rodrigues, K.F.; Romero, R.; Rosa, P.; Silva-Gonçalves, K.C.; Souza, M.L.D.R.; Woodgyer, E. 2015. Melastomataceae. In: Lista de Espécies da Flora do Brasil. Jardim Botânico do Rio de Janeiro. Disponivel em $\quad<$ http://floradobrasil.jbrj.gov.br/jabot/ floradobrasil/FB161>. Acesso em 21 nov 2016.

BFG [The Brazilian Flora Group] 2015. Growing knowledge: an overview of Seed Plant diversity in Brazil. Rodriguésia 66(4): $1085-1113$.

Campos, B.C. 2005. A Família Melastomataceae nos Campos Rupestres e Cerrado de Altitude do Parque Estadual do Ibitipoca, Lima Duarte, Minas Gerais, Brasil. Dissertação de Mestrado. Escola Nacional de Botânica Tropical - Instituto de Pesquisa, Jardim Botânico do Rio de Janeiro.

Cogniaux, A. 1885. Melastomataceae. Tribus II. Tibouchinieae. In: C.F.P Martius \& A.G. Eichler (eds), Flora Brasiliensis. Vol. 14, pars 3. F. Fleischer, Lipsiae, p. 5-480.

Fagundes, M.C. \& Santos, A.K.A. 2016. Flora da Bahia: Melastomataceae - Tribo Merianieae s.l. Sitientibus série Ciências Biológicas 16: 10.13102/scb1120.

Freitas, J.G. 2011. Estudos Floristicos e Taxonômicos em Tibouchina Aubl. (Melastomataceae; Melastomeae) no Estado da Bahia, Brasil. Dissertação de Mestrado. Universidade Estadual de Feira de Santana, Feira de Santana.

Freitas, J.G.; Santos, A.K.A. \& Oliveira, R.P. 2012. Tibouchina bracteolata and T. comosa (Melastomataceae, Melastomeae): two new species to the Chapada Diamantina, Bahia, Brazil. Systematic Botany 37(1): 189-196.

Freitas, J.G.; A.K.A. Santos \& R.P. Oliveira. 2013. A new and unusual species of Tibouchina (Melastomataceae) occurring in Caatinga vegetation in Bahia, Brazil. Systematic Botany 38(2): 418-423.

Goldenberg, R.; Baumgratz, J.F.A. \& Souza M.E.D. 2012. Taxonomia de Melastomataceae no Brasil: retrospectiva, perspectivas e chave de identificação para os gêneros. Rodriguésia 63(1): 145-161.

Guimarães, P.J.F. \& Freitas, J.G. 2015. Two new species of Pleroma (Melastomataceae) from Brazil. Systematic Botany 40(2): 553-560.

Guimarães, P.J.F. \& Martins, A.B. 1997. Tibouchina sect. Pleroma (D. Don) Cogn. (Melastomataceae) no estado de São Paulo. Revista Brasileira de Botânica 20: 11-33.

Markgraf, F. 1927. Plantae Luetzelburgianae brasiliensis Melastomataceae. Notizblatt des Botanischen Gartens und Museums zu Berlin-Dahlem 10(91): 50. 
Matsumoto, K. \& Martins, A.B. 2005. Melastomataceae nas formações campestres do município de Carrancas, Minas Gerais. Hoehnea 32(3): 389-420.

Meyer, F.S. 2008. O Gênero Tibouchina Aubl. (Melastomataceae) no Estado do Paraná, Brasil. Dissertação de mestrado. Universidade Federal do Paraná.

Meyer, F.S.; Guimarães, P.J.F. \& Goldenberg, R. 2010 Tibouchina (Melastomataceae) do estado do Paraná, Brasil. Rodriguésia 61: 615-638.

Michelangeli, F.A.; Guimarães, P.J.F.; Penneys, D.S.; Almeda, F. \& Kriebel, R.. 2013. Phylogenetic relationships and distribution of New World Melastomeae (Melastomataceae). Botanical Journal of the Linnean Society 171: 38-60.

Oliveira, C.M.S. 2001. Tibouchina sect. Diotanthera, Diplostegia, Pseudoptrolepis, Purpurella e Simplicicaules (Melastomataceae) no estado de São Paulo. Dissertação de Mestrado. Universidade Estadual de Campinas.
Peralta, P. 2002. Las espécies del género Tibouchina (Melastomataceae) en Argentina. Darwiniana 40(1-4): 107-120.

Renner, S.S. 1993. Phylogeny and classification of the Melastomataceae and Memecylaceae. Nordic Journal of Botany 13(5): 519-540.

Renner, S.S. 1994. A revision of Pterolepis (Melastomataceae: Melastomeae). Nordic Journal of Botany 14: 73-104.

Renner, S.S.; Triebel, D.; Almeda, F.; Stone, D.; Ulloa, C.U.; Michelangeli, F.A.; Goldenberg, R. \& Cifuentes, H.M. 2016. Melastomataceae. Net. 2016. A site with information on the biodiversity of Melastomataceae. Disponível em <www. melastomataceae.net>. Acesso em 22 Out 2016.

Secco, R.C. 2006. Estudos Taxonômicos no Gênero Comolia DC. (Melastomataceae) no Brasil. Dissertação de Mestrado. Universidade Estadual de Campinas.

\section{LISTA DE EXSICATAS}

Abbas, B.A. 82 (16); Adamek, M. 17 (17); Adolpho, L. 360 (2); Almeida, E.F. 130 (17); Almeida, L P. 31 (35), 35 (16), 46 (35), 119 (13); Alves, M. 872 (35); Alves, L.J. 92 (14); Alves, M. 872 (35); Alves, R.J.V. 108, 949, 5253, 5375, 5549 (9); Alves-Araújo, A. 55 (17); Amaral, D.L. 60 (30); Amorim, A.M. 1746, 3836 (36), 4787, 5161 (14), 5486 (15), 5567, 5938 (14), 6174, 6272 (18), 7134 (2); Anderson, W.R. 10016 (12); Andrade, C.T. 2 (34); Andrade, G.A. 1181 (9); Araujo, A. 2, 80 (5), 42 (7), 88 (8); Araujo, D. 349 (21), 7575 (35); Araujo, F.S. 16 (17); Arbo, M.M. 5395 (5), 5735 (1), 5799 (25), 7124 (15), Assis, L.C.S. 24 (16), 537 (30); Azevedo, C. 30 (14); Baitello, J.B. 2018, 2027, 2028 (30); Bamps, P. 5054 (33); Barcia, L. 117 (2); Barreto, A.C. 76 (7); Barreto, M. 4679 (9), 6192 (16), 6877 (30), 6923, 9787 (9); Barreto, V. 196 (14); Bastos, S.K.M. 4 (34); Bastos-Accioly, J.A. s.n. PEUFR 21543 (7); Baumgratz, J.F. 122 , 148 (21), 734 (9), 747 (25), 1108 (17); Bautista H.P. 110, 167 (4), 322 (5), 1111, 1154 (26), 1187 (7), 1207 (18), 1231, 1232 (5), 3002 (26), 3073 (14), 4003 (1) 4299 (18); Belém, R.P. 854 (13), 2757 (35), 2960 (13), 3134 (35), 3245 (4), 3247 (13); Bertoloni, J.E.A. 319 (9), 133, 336, 486 (30); Bocage, A. 1074 (17); Bonfim, M.A. 14 (17); Boone, W. 26 (17); Borges, R.A.X. 293 (2); Bovini, M.G. 2216 (2); Brade, 18181 (17); Braga, J. s.n. MBM 158602 (16); Braga, J.M.A. 7305 (21); Brazão, J.E. 190 (14), 364 (21); Brito, D.S. de 21 (30); Brito, N.M. 82 (17); Bruggh, M. 17410 (17); Cajaíba, A.F.F. 1 (34); Carauta, J.P.P. 428 (17), 508 (35), 3328 (17); Cardoso, D. 1045 (35), 1466 (22), 1605 (14); Carneiro, J. 284 (16); Carneiro-Torres, D.S. 527 (36); Carvalho A.M. 354 (33), 845 (35), 914 (3), 1008,1023 (25), 1031 (5), 1036 (23), 1055 (25), 1129 (4), 1521, 1527 (18), 1615 (15), 1916 (7), 1958, 1983, 1999 (8), 2153 (25), 2175 (4), 2301 (17), 3056,3096 (14), 3076 (36), 3225 (18); 4184 (5), 6149 (36), 7020 (17); Carvalho, R.A. 1 (30); Carvalho-Sobrinho, J.G. 148 (22), 2747 (18). Castro, R.M. 930 (17), 1082 (23); Cerqueira, A.S. 2 (15); Chamas, C.C. 55 (2), 102, 113, 119 (14), 136, 146 (17), 320, 324 (2), 370 , 440 (18); Cid, C.A. 4336 (30); Cielo-Filho, R. 674 (30); Conceição, A.A. 434 (10), 801 (10), 820 (10), 825 (23), 1209 (25), 1224 (4), 2220 (5); Conceição, A.S. 410 (5), 466 (21), 509 (4), 634, 731 (14), 896 (17), 1618 (5); Conceição, S.F. 303 (5), 398 (35); Coradin, L. 6226, CEN9331 (5), 6532 (4); Costa, A. L. 2 (34), 528, 567 (35), 980 (7), 983 (35); Costa, E. 266 (17); Costa, G. 27 (25), 82, 98 (5); Costa, M.A.A. 243 (25); Costa, T.A.B. 22 (23); Couto, A.P.L. 127 (22); Demuner, V. 408 (2); Dias, A.A. 79 (11); Duarte, A.P. 4767 (35), 5181 (16), 6143 (13), 6596, 9111 (21), s.n. RB 149048 (17); Duarte, H. 2667,2731 (30); Emperaire, L. 2719 (5); Estevo, F.E.E. 83 (7); Euponino, A. 73 (35), 131 (14), 238 (13), 467 (14), 477 (13); Faria, E. 17 (5); Farias, G.L. 153 (30); Faria, G.A. 194 (17); Félix, L.P. 8626 (5); Fernandes, D. 609 , 676 (16); Fernandes, H.Q.B. 2374 (17); Fernandes, N.Q.B. 1587 (2); Ferney, C. 4230 (16); Ferreira, F.M. 26 , 55 (17); Ferreira, J.L. 148 (36), 326 (19); Ferreira, M.C. 82 (14), 189 (23), 238 (27), 468 (21), 1212 (1), 1880 (14); Ferreira, V.S. 2 (25), 92 (4); Ferreira, W.M. 279 (14), 513, 594 (30); Ferreira-Silva, A. 11 (4); Fiaschi, P. 1440, 2255 (15), 2455 (5); Fina, B.G. 130 (30); Flaster, B. 1069 (2); Folli, D.A. 877 (35); Fonseca, M.L 5350 (30); Fonseca, M.R. 41 (35); Fonseca, W.N. 353 (36); Fontana, A.P. 856 (17), 1100 (2), 1410 (17); Fontella, J. 3202 (35); Forzza R.C. 1174 (25), 1240, 1270 (19), 1340, 2851 (17), 3877 (36), 3978 (17); Fothergill, J.M. 43 (25); França, F. 1370, 1517, 1622, 2119 (19), 2440 (36), 2647 (5), 2652 (23), 3039 (36), 3994 (5), 4037 (4), 4355 (17), 4399 (26), 4944 (30), 4952 (22), 5165 (19), 5371 (5), 5920 (25); Freire, V. 102 s.n. R 114942 (16); Freitas, I. 2 (34); Freitas, J.G. 537 (4), 538 (25), 542 (23), 545 (10), 548 (16), 550 (17), 551, 552 (16), 553 (17), 554 (18), 555, 557 (15), 611, 612 (25), 613, 614 (5), 642, 643 (18), 644 (16), 645 (17); Funch, L.S. 118, 437, 1604 (4), 2008 (25), 2063 (14); Funch, R. 80 (14), 270 (4), 641 (10); Ganev, W. 36 (23), 320 (1), 233 (36), 878,1057 (9), 1436 (21), 2045 (20), 3079 (23), 3490 (25); Gasson, P. 6197 (14); Gentry, A.L. 50001 (24); Geraldes, S.S. 7 (34); Gibbs, P.E. 5298 (17); Giordano, L.C. 39 (16), 45 (17), 56, 908 (16), 1226 (15); Giulietti, A.M. 1559 (20), 1637 (25), 1854 (22), 1927, 2679 (4), 2288 (5), 2680 (35), 2773 (36); Glaziou, 15986 (14), 15992 (16), 16796, 21372 (9); Glocimar, P.S. 3672 (34); Godoy, S.A.P. 1378 (30), 1795, 1799, 1802, 1880 (9); Góis, O.C. 27 (2), 107 (14), 986 (16); Gomes, P. 587 (17); Gonçalves, J. M. 107(5); Gonçalves, L.M. C. 220 (17); Graças, M. 943, 966 (25); Guedes, M.L. 672 (4), 754 (4), 1236 (18), 1423, 1428 (4), 1477 (23), 1525 (5), 1996 (4), 2111 (13), 2731 (5), 2733 (36), 2906 (35), 3022 (15), 3426 (18), 3487, 3577 (35), 3588 (21), 3624 (18), 3676 (15), 3992 (35), 4752 (4), 4959 (5), 5016 (18), 5223 (25), 6023 (7), 6161 (5), 6350 (17), 8903, 8956, 9025 (35), 9447 (4), 9841, 10741 (5), 11220 (13), 11229 (4), 11234 (25), 11256 (18), 11282 (4), 11334 
(25), 11391, 11687, 12192 (35), 12391, 13299 (25), 13836 (35), 14171 (5), 14852 (36), 14767 (35), 16682 (1); Guimarães, B. 02 (7); Guimarães, J.P.F. 320 (21), 324, 326, 361, 365 (2), 339, 348 (17), s.n. (SP 372033) (33), s.n. SP 37233, s.n. RB 413013 (34); Gusmão, E. F. 352 (18); Hage J.L. 152 (3), 527 (24), 670, 1884 (16); Harley, R.M. 2763 (14), 3288 (36), 5306, 15349 (9), 15468 (25), 15717,15823 (14), 17391, 17392 (13), 17951, 18012 (21), 18013 (28), 20643 (4), 20855 (23), 22331 (10), 22399 (5), 22483 (10), 22649 (8), 22880 (4), 24555 (25), 25306 (9), 26282, 26429 (25), 26479 (1), 27358 (25), 27392 (15), 28318 (9), 28397 (20), 53508 (5), 53701 (14), 54067 (4), 54223, 54232 (25), 54270, 54397, 54474 (23), 54672, 54680 (20); Hatori, E.K.O. 277 (30); Hatschbach, G. 26961, 27290 (9), 45055 (19), 53360 (20), 39605 (5), 43726 (30), 46958, 47775 (21), 47522 (4), 48977 (17), 49689 (9), 50722 (21), 5269 (17), 58099 (21), 59260,62520 (30), 75079 (21), 75220 (35), 75795 (19), s.n. MBM 229485 (36), s.n. MBM 97903 (17), s.n. MBM 283885 (17); Heringer, E.P. 613 , 10170 (17), 15542 (30); Hind, D.J.N. 3168 (5); Hoehene, F.C. 6702, 6703, 6814, 6816 (17), 23884, s.n. R 7196 (30); Hoenhe, W. 2444, s.n. SPF 11843 (30); Ibrahim, M. 113 (13); Irwin, H.S. 5243 (30), 5401 (9), 24925 (30), 32248, 32265 (5), 32433 (4); Jardim J.G. 40 (5), 2816 (34), 4413 (14), 4649 (7), 4826 (2); Jesus, J.A. 601 (13); Jesus, N.G. in PL 25 (15), in PC 148, 246, 466 (18), 1321 (36); Joly, A.B. 3234 (9); Junqueira, M.E.R. 54 (36); Karal, R. 72848 (25); King, L.R.M. 8718 (4), 8775 (25); Kirkbride, H. 4428 (9), 4550 (28), 4746,5188 , 5293 (30), 5375 (9); Kollmann, L. 156 (14), 1190, 2424 (2), 1934, 3556 (18), 5125 (2), 6402 (17), 6465 (2), 6467 (36), 6499 (21), 6831 (17), 7233 (2), 7435, 7444, 7476 (17); Krapovickas, A. 23212 (35), 42162 (16); Krieger, L. 18643 (21), 8633, 9912 (17), 18643 (21); Kuhlmann, M. 4398 (36); Labouriau, 281(17); Landim, M. 1402 (15); Lanna, 1923 (30); Lara, L. 2 (34); Leite, K.R.B 44 (19); Lima S.S. 82 (13); Lima, H.C. 823 (5), 6395 (2); Lima, J.C.A. 310 (25); Lima, L.P. 896, 1633, 12708, 12754, 13162 (13); Lima, M.R.O. 20 (4), 21 (13), 24 (4), 25 (14); Lima, S.S. 82 (4); Lira, S. 18288 (17); Lôbo, C.M.B. 29 (36); Lombardi, J.A. 436 (9); Longa, C.M. 11 (18); Lopes, M.M.M. 304 (2); Lordelo, R.P. 56535 (18); Lorry, R.N. 123 (10); Louis, O.W. 5991 (30); Loureiro, D.M. 413 (13), 470 (25), 636 (14), 768 (13); Luchiari, C. 38, 325, 554 (2); Lutz, B. 60 (17), 1271, 1608 (16); Ferreira, M.C. 82 (14); Maas P.J.M. 7027 (13); Macedo, A. 1160 (9); Macedo, W. 85 (9); Machado, M. 237 (5); Magalhães, G. 269 (14); Magnanini, C. 3 , 21 (16); Magnanini, C. s.n. R 166397, 103 (16); Maia, H. 22 (18); Maioli, V. 922 (17); Markgraf, 3786 (35); Marcon, A.B. 250 (25); Marquete, E.L. 1563, 1856 (16), 3260 (14); Martineli, G. 524 (5), 990 (35), 1322 (17), 6010 (21), 6647 (8), 12939 (2); Matos, J. 14507 (30); Matos-Silva L.A. 398 (15), 405 (24), 710 (15), 709 (21), 1642, 1718, 2429 (13), 2830 (25), 4000 (17), 4242 (21); Melo E. 1106 (22), 1172 (5), 1199 (25), 1355, 1580 (19), 1778 (10), 2183 (22), 2856 (9), 3391 (2), 3915 (19), 4167 (35), 4613, 4830 (5), 7968 (18); Melo, J.C.F. 738 (16); Melo, L.E. de 4302 (30); Mello-Silva, R. 7615 (14), s.n. RB307842 (9); Mendes, M.S. 510 (25); Mendes, S. 201 (4); Mendonça, F.B. 253 (16); Menezes, C.M. 456 (13); Mesias, M. s.n. RB215692 (16); Miranda, A.M. 228 (14) 3552 (17) 5402 (35); Miranda, C.A. 493 (18); Miranda, E.B. 151 (14), 162 (36), 575, 780 (17); Miranda, L.A.P. de 95, 96, 98 (14); Miranda, V.F.O. 411 (30); Monteiro, M.T. 616 (13); Monteiro, S. 159 (16); Moraes, A.O. 45 (19), 305 (5); Moraes, M.V. 450, 802 (18); Moreira, I.S. 67 (35); Mori, S.A. 9341 (15), 9934, 10726 (3), 11277 , s.n. RB211255 (5), 12422, 12529 (25), 12557 (2), 12615, 12946 (25), 12999 (17), 13535, 14350 (25), 13426 (14), 14387 (10), 16936 (9); Morretes, B.L. 13 (4); Mota, A.M.C. 4620 (30); Mota, E. 18 (17); Monteiro, M.T. 1602 (13); Nadruz, M. 226, 230, 232, 234, 250 (16), 1924 (2); Nakajima, J.N. 504, 583, 2682 (9); Nascimento, A.F.S. 208 (15); Nascimento, C.B. 19 (7); Nascimento, F.H.F. 51 (9), 166,370 (14); Nascimento, J.G.A. do 200 (5), 301, 311 (23); Neto, F.M. s.n. MBM285774 (9); Neves, E.L. 26 (7); Neves, S.P.S. 32, 43, 56, 146 (25), 239 (5); Nirkbride, J.H. 4428, 5375 (9); Noblick L.R. 1130 (23), 1314, 1733 (35), 1780 (14), 2109 (18), 2153 (13), 2710 (17), 2785 (5), 2788 (25), 3054 (4), 3173 (22), 3233 (34), 3336 (14), 3422 (7), 3733 (35), 4569 (36), 4572 (5), 11305 (23); Nobrega, M.G. 345 (9); Nonato, F.R. 880 (14), 909 (36); Nunes, T.S. 67 (9), 1439 (4), 1674 (17); Oliveira, A. 4 (34); Oliveira, E.E.R. 62 (18); Oliveira, H.C. s.n. HUEFS4519 (34); Oliveira J.S. de. 41 (13); Oliveira, P. I. 402 (30); Oliveira, P.P. 5 (34), 6 (5), 78, 93 (30), 89 (35) 140 (30); Oliveira, R.P. 848 (17), 1555 (18); Orlandi, R. 268 (10), 335 (36), 423 (25), 435 (18), 560, 562 (25); Pabst, G. 4895 (2), 7122 (9), 7394 (2), 9059 (36); Pada, J. S. 72 (16); Pagano, S.N. 505 (30); Paixão, J.L. 243, 846, 486 (14) 711 (9), 717 (25), 746 (23); Paschoaletti, L.F.G. 10 (23); Passos, L. 265 (14), 5038 (25); Paz, J.R.L. da 8 (35); Peixoto, A.L. 452 (17); Pereira, A. 45 (14), in PCD 1744 (25); Pereira, B.A.S. 496, 603, 2769 (30); Pereira, E. 1980 (18), 2364, 3204, 3236 (30), 4210 (16), 7345 (30), 9182 (9), 9850 (14), 10765 (30); Pereira, O. J 140 (21); Pessoa, L. 367 (33), 452 (2); Pietrobom-Silva, M.R. 4598 (17); Pifano, D.S. 96 (2); Pinheiro R.S. 1471 (24), 1772 (35); Pinheiro, F. 47 (16); Pinheiro, M.H.O. 2006 (30); Pinto, G.C.P. 05 (17), 41 (19), 100 (14), 168 (19), 265 (18), 380 (2), 444 (10), 1207 (18), 1809 (36), 2275 (19), 42307 (18), 5763 (35), 9100 , s.n. ALCB15192 (33); Pirani, J.R. 2076 (25), 5384 (14); Popovkin, A.V. 441,453 (15), 609 (17); Poveda A. 548 (25); Queiroz, E.P. 102 (16), 693 (35), 1363 (18), 1467 (17), 2781 (14), 3308 (9); Queiroz, L.P. 415 (7), 505 (35), 889 (7), 9481 (5),1051 (18), 1214 (36), 1263 (5), 1363 (18), 1372 (15), 1577 (14), 1589 (34), 1839 (4), 1915 (36), 1928, 1931 (1), 1982 (5), 2955 , 2976, 3132 (34), 3284 (8), 4263 (5), 4365 (25), 5129 (36), 5422 (5), 5497 (36), 5625 (4), 9739 (5); Ramalho, F.B. 211 (16), 1242 (14); Ramalho, R.S. 1076 (16), 2624 (9); Ramos, A.E. 489 (30), 1137 (25); Ramos, C.E. 226 (17); Ratter, J.A. 3269 (9); Ribeiro T. 206 (14), 346 (9); Ribeiro-Filho, A.A. 7 (21), 177 (14); Rivello, N. 2 (35); Rizzo, A. 4160 (12); Rocha, F.T. s.n. SPF11745 (16); Rodarte, A.T. 12 (14), 20 (21); Rodrigues, I.A. 39 (16); Rodrigues, L. 7 (16), 8 (34), 21 (16); Romaniuc-Neto, S. 460 (30); Romero, R. 1140 (9), 2172 , 2501 (17), 8624 (30); Roque, N. 561 (25), 1403, 1601, 1619 (4), 1705 (5), 1934 (14), 1994 (25); Rosa, P. 138 (16); Rylands, A. 186 (13); Saavedra, M.M. 715 (17); Salairagui, C.M. 103 (9); Salgado, O.A. 179 (9); Salimena-Pires, F.R. 2140 (1), 24675 (17); Sampaio, s.n. R16640 (18); Sandrini, P.S. 89 (16); Sant'Ana, S.C. 79 (13), 843 (15), 965 (9); Santana, A.S. 57 (35); Santana, D.I. 331 (14), 645 (36), 655 (35); Santos, A.K.A. 8, 9 (25), 45, 52 (22), 76 (23), 83 (23), 84, 89, 90 (25), 139 (9), 268 (36), 302 (25), 332 (5), 349 (36), 361 (5), 368 , (25), 494, 538 (35), 829 (23); Santos, E. 1650 (30), 2032, 2189 (2); Santos, E.B. 284 (23); Santos, F.S. 628 (14); Santos, N.C.R. 25 , 25160 (18); Santos, R.B. 14 (4); Santos, R.H. 22 (16); Santos, R.S. s.n. MBM41878 (18); Santos, T.R. 1764 (24), 2716 (3), 5642 (4), 5782 (14); Santos, V.J. 244, 387, 518 (14); Santos Filho, L.A.F. 67 (16); Santos-Silva, J.R. 3 (7); Saporetti, J.A.W. s.n. RB469716 (21); Sasaki, D. 331 (17); Schwacke, 5018 (16); Semir, J. 19.513 (17); Silva, A.C.B. 2 (9), 214 (16), 312 (17), 346, 390,391 (30), 423 (17), 584 (9), 817 , 878, 917 (17); Silva, A.F. 2218 (2); Silva, E.L. 12 (16); Silva, F.C.F. 2 (22), 08 (9), 58 (30); Silva, G.P. 3672 (34); Silva, J.S. 241 (17); Silva, M.F.O. da s.n. UPCB65673 (16); Silva, M.M. da 144 (9); Silva, P.M.R. 2265 (30); Silva, S.F. 9 (13); Silva, T.R.S. 233 (25); Silva- 
Castro, M.M. 680 (36); Silva-Pereira, V. 15 (25), 56 (4); Simon, M.F. 232 (25); Soares e Silva, L.H. 1149 (30); Sobral, M. 3587 (35); Sousa, A. 11 (34), 39 (14), 47, 251 (36), 252 (14); Sousa, A.E.A. 65 (14); Souza, E.B. 942 (25), 1002, 1028 (23), 1040 (17); Souza, J.P. 4819 (5); Souza, L.M. 34, 138 (30); Souza, V.C. 22840 (25), 2577 (30); Souza, W.S. 737 (30); Spada, J. 85 (21); Stalcup, M. 74 (16); Standard, B. 51738 (14), 51933 (37) 51980, 53352 (14); Stradmann, M.T.S. 177 (25), 672 (5), 731 (25), 811 (14); Strang, H. 933 (16); Sucre, D. 808 (9), 5339, 8365 (35), 8370 (21); Talmon, S.S. 1684 (31); Teixeira, S.J. s.n. RB331372 (9); Thomas, W.W. 10042 (21), 11041 (35), 12948, 13806 (14), 13452 (13), 8978 (15); Torrend, C. 3 (5), 4 (18); Tosto, M.G. 53 (35); Wanderley, M.G.L. 1603, 1606, s.n. SP210119 (5); Vailant, P. 110 (9); Vailant, P.F.M. 62 (14), 121 (21); Valadão, R. 498 (17), 685 (13); Valente, M.C. 1 (16); Valls, J.F.M. 9201 (30); van den Berg, C. 885, 903 (22), 1074 (30); Velloso, H. 388 (14), 646 (2); Viana, B.F. 21 (7); Viana, G. 968 (15); Viana, S. 4493 (35); Vidal, J. 592, 908 (30); Vieira, C.M. 1050 (15); Vieira, D.R. 4 (18). 